BRUNA DE OLIVEIRA MENDES

\title{
A Democracia Constitucional E AS TEORIAS DO DIÁLOGo INSTITUCIONAL
}

Dissertação apresentada à Faculdade de Direito da Universidade de São Paulo (FDUSP) como requisito parcial para a obtenção do título de Mestre em Direito.

Área de Concentração: Direito do Estado.

Orientador: Professor Doutor Rubens Beçak

Faculdade de Direito da Universidade de São Paulo

SÃO PAULO 
Nome: MENDES, Bruna de Oliveira

Título: A Democracia Constitucional e as Teorias do Diálogo Institucional.

Dissertação apresentada à Faculdade de Direito da Universidade de São Paulo (FDUSP) como requisito parcial para a obtenção do título de Mestre em Direito.

Aprovada em:

Banca Examinadora

Prof. Dr.

Instituição:

Julgamento:

Assinatura:

Prof. Dr. Instituição:

Julgamento: Assinatura:

Prof. Dr. Instituição:

Julgamento: Assinatura: 


\section{- DEDICATÓRIA E AGRADECIMENTOS -}

Agradeço ao Professor Rubens Beçak pela confiança depositada na minha pesquisa, bem como pelo incentivo constante; aos meus amigos próximos, por acreditarem no meu projeto de vida e me encherem de coragem; à minha família querida e divertida, por proporcionar-me tantos bons momentos e fazer-se sempre presente nos sufocos - a todos e cada um de vocês. Reconhecimento especial à contribuição de Sérgio Antônio Ferreira Victor, que compartilhou comigo material acadêmico de relevância.

Dedico essa dissertação: à minha mãe, por não me deixar esquecer de sonhar, mas também pelo exemplo diário de como manter os pés no chão; ao meu irmão, pela parceria verdadeira e pelo generoso e valiosíssimo presente da aceitação; ao meu pai, de quem herdei o dom da alegria e da intensidade; e à minha vó Eurídice, que foi tantas em uma só, e a quem ainda venho descobrindo. 
"In its ideas about itself and about society, as in all its other endeavors, the mind goes from mastery to enslavement. By an irresistible movement, which imitates the attraction death exercises over life, thought again and again uses the instruments of its own freedom to bind itself in chains. But whenever the mind breaks its chains, the liberty it wins is greater than the one it has lost, and the splendor of its triumph surpasses the wretchedness of its earlier subjection. Even its defeats strengthen it. Thus, everything in the history of thought happens as if it were meant to remind us that, though death lasts forever, it is always the same, whereas life, which is fleeting, is always something higher than it was 


\section{Resumo:}

A tradição histórica da doutrina e prática constitucionais elegeu o Poder Legislativo como o centro por excelência de manifestação das aspirações de autogoverno. A revisão judicial, nesse cenário, costuma suscitar críticas e defesas das mais variadas, que contrapõem seu exercício à consolidação de direitos engendrada, por sua vez, no âmbito das legislaturas. Para uma compreensão geral do debate travado, é necessário compreender as raízes históricas norte-americanas do instituto da revisão judicial, assim como as teorias construídas para analisar o comportamento daqueles responsáveis por praticá-la - os juízes. À luz de um renovado modelo comportamental fundado em aspectos institucionais, está-se diante de mudança de perspectiva quanto à análise da realização de direitos por diferentes atores políticos. Nesse sentido, não há que se falar na autoridade sobre “última palavra” decisória, mas na melhor solução por meio da interação entre instituições, no contexto das teorias do diálogo.

Palavras-chave: Constitucionalismo; Democracia; Jurisdição Constitucional; Legitimidade; Teorias do Diálogo; Neoinstitucionalismo. 


\begin{abstract}
:
Traditional doctrine and constitutional practice have elected Parliament as the ultimate center for aspirations of self-government. Judicial Review, on that perspective, usually brings about all sorts of critics and defenses, in comparing its practice with the realization of rights entailed by legislative action and with regard to its legitimacy. For a general comprehension of the matter, one must first understand the historical roots of Judicial Review's American origins, as well as the theories constructed in order to analyze the behavior of those responsible for practicing it - the judges. In light of a renewed model for behavioral analysis that enhances the focus on institutional features, there is a change in perspective when it comes to the implementation of rights. No theories of "last word" on decisional authority can account for the new objectives in mind, since the best solution should be found through the interaction between institutions, an ideal prescribed by dialogue theories.
\end{abstract}

Key-words: Constitutionalism; Democray; Judicial Review, Legitimacy, Dialogue Theories; Neoinstitutionalism. 


\section{SUMÁRIO}

INTRODUÇÃO 10

\section{CAPÍTULO I \\ DAS ORIGENS NORTE-AMERICANAS \\ DA JURISDIÇÃO CONSTITUCIONAL AO MODELO “NEOINSTITUCIONAL”}

1. Cresce o poder da vontade popular - é hora de temperar a democracia.................. 21

2. A influência federalista no desenho da República americana................................. 23

3. A Convenção de Filadélfia e o Poder Judiciário...................................................... 25

4. Contextualizando Marbury v. Madison no cenário político de então..................... 28

4.1 O controle de constitucionalidade de leis estaduais na esfera federal............ 32

5. Novos desafios econômicos, os mesmos velhos embates institucionais................. 33

5.1 A era progressista na base da tensão contramajoritária................................ 34

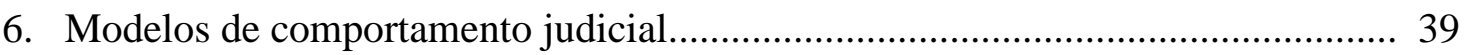

6.1 Considerações político-sociais sobre o Judicial Review americano............... 39

6.2 Superando a dicotomia legalista $\mathrm{x}$ atitudinal -0 modelo "neoinstitucional". 40

\section{CAPÍTULO II \\ CORTE X PARLAMENTO: \\ A PERSPECTIVA DA “ÚLTIMA PALAVRA”}

1. Visões críticas sobre o Poder Judiciário e a Jurisdição Constitucional.................. 44

1.1 A supremacia do Legislativo na voz de Jeremy Waldron............................... 44

1.2 Repensando Waldron na voz de Whittington................................................ 46

1.3 Frederick Schauer e a "Constituição modesta”............................................. 50

1.4 Argumentos centrais da doutrina...................................................................... 55

1.4.1 A corte não protege as precondições da democracia, pois não está fora da política.................................................................................................. 56 1.4.2 A corte não protege direitos de minorias: moralmente, isso é controverso; empiricamente, isso é falso.................................................... 57 1.4.3 A corte não é emissária do poder constituinte nem mecanismo de précomprometimento. Esse é um disfarce que encobre um agente político que faz escolhas morais controversas...................................................................... 58 1.4.4 A corte, de fato, pode ter sua decisão rejeitada, ao final, pelo poder de emenda ou por uma nova constituição. Essa dificuldade, porém, não se justifica. 
1.4.5 A revisão judicial não é decorrência necessária do estado de direito e não deve ser exclusividade na interpretação da constituição. Interpretações do parlamento podem prevalecer.... 59 1.4.6 A corte não é um agente externo que julga com imparcialidade, pois não está fora da política. Alguém precisa decidir por último, e nenhum dos possíveis candidatos a essa autoridade será neutro. 60 1.4.7 O controle de constitucionalidade não é mera decorrência da dinâmica da separação de poderes. Não há razão para que tenha a última palavra. 61 1.4.8 No controle de constitucionalidade, a corte não analisa exatamente um caso concreto diferente dos casos concretos que informam a deliberação de uma lei. 61

1.4.9 A corte é igualmente falível em questões de princípio, e pessoas discordam sobre respostas corretas.

1.4.10 A corte não promove uma representação deliberativa ou argumentativa. Juízes não representam, não são eleitos, e sim uma elite profissional.

1.4.11 A corte não é instituição educativa, nem promove um debate público melhor do que o legislador. Está presa a uma linguagem empobrecida, verborrágica, inflexível e amarrada a tecnicalidades jurídicas.

1.4.12 A corte integra um sistema democrático, mas não deve ter a última palavra..... 65

1.4.13 A corte é composta de membros indicados por autoridades eleitas, mas este mecanismo não é suficiente para a prestação de contas democrática. 65

2. Do outro lado das trincheiras: as Legislaturas sob ataque. 66

2.1 A supremacia do Parlamento inglês e a teoria do modelo de Judicial Review do Common Law. 66

2.2 Argumentos centrais da doutrina.. 68

2.3 A democracia representativa em foco. 69

2.4 Ataques à ideia de representação

2.4.1 O parlamento não é a encarnação essencial da democracia, mas a conversão de uma instituição que historicamente exerceu outros propósitos.

2.4.2 A dinâmica representativo-eleitoral incentiva um comportamento legislativo que barateia direitos fundamentais..... 75 2.4.3 A representação eleitoral não é o único tipo possível de representação. Trata-se de uma representação puramente agregativa, atomística, que pensa a política como mercado. 76 2.4.4 Restrições ao parlamento eleito não resgatam argumentos da tradição antidemocrática. Simplesmente apontam problemas que os incentivos institucionais geram no comportamento do legislador.................................. 77

2.5 Ataques à regra da maioria...... 78

2.5.1 A regra da maioria é insensível à intensidade de preferências. 78 
2.5.2 A regra da maioria não tem a racionalidade que parece. Seu resultado é arbitrário................................................................................................ 79

2.5.3 O mundo não é bipartido entre minoria e maioria. Preferências políticas, ademais, não são estáticas........................................................................ 79

\section{CAPÍTULO III \\ O DIÁLOGO INSTITUCIONAL}

1. Influências institucionais à atuação da Corte...................................................... 81

1.1 Os momentos iniciais de uma nova ordem constitucional............................. 82

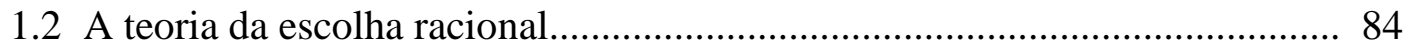

1.3 O Brasil e os mecanismos de reação ao STF................................................. 87

2. O diálogo constitucional canadense e a teoria da construção coordenada............. 91

3. O Brasil e a verificação dos pressupostos dialógicos na prática

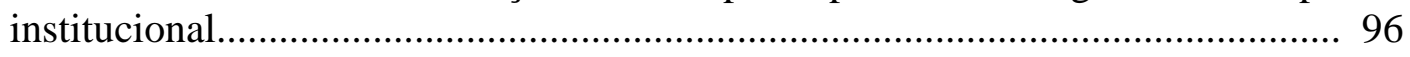

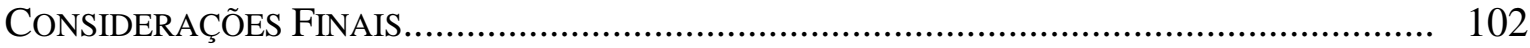

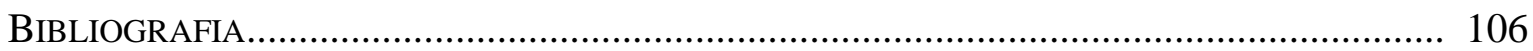




\section{- INTRODUÇÃO -}

Discursos sobre quem deveria possuir a última palavra no significado da Constituição originam tensão não apenas entre Parlamentos e Cortes, mas também entre dois valores políticos - Democracia e Constitucionalismo, respectivamente. Em um raciocínio linear simplificado, o governo do povo esbarraria na necessidade de que limites lhe fossem impostos pela própria estrutura do Estado. Trata-se da igualmente simplificada e recorrente dicotomia erigida entre os ideais de demandas procedimentais, de um lado, e de demandas substantivas, do outro. Ironicamente, a combinação de ambos os ideais como fundamento de legitimidade do regime político adotado foi a opção da maior parte das nações ocidentais durante o século XX, e a expressão “democracia constitucional” foi a convencionada para designá-lo.

Retomando conceitos, pode-se afirmar que a consolidação da democracia constitucional é indissociável da construção histórica do que hoje se denomina "Estado de Direito” ${ }^{1}$. A origem do Estado de Direito em sua concepção material está nas revoluções liberais, quando o Estado burguês ganhou forma e buscou sepultar o absolutismo monárquico no final da Idade Moderna. Como forma de garantir a liberdade política, a ideia de Estado de Direito veio a se materializar na exigência da separação dos poderes do Estado, que, nos termos do art. 16 da Declaração de Direitos dos Homens e dos Cidadãos (1789), é inerente à própria ideia de Constituição ${ }^{2}$. É a origem, pois, do Estado Constitucional.

\footnotetext{
${ }^{1}$ A despeito das mudanças propulsionadas pelas revoluções liberais, vale ressaltar que a origem do termo "Estado de Direito" remonta à doutrina alemã do século XIX (Rechtsstaat), e só será definitivamente introduzido na doutrina francesa a partir do século XX, por Raymond Carré de Malberg.

${ }^{2}$ BARROS, Sérgio Resende de. Contribuição dialética para o constitucionalismo. São Paulo: Editora Millennium, 2008.
} 
Como, portanto, encontrar o delicado ponto de equilíbrio entre as demandas mencionadas (procedimentais x substantivas) e, em última instância, entre o Parlamento e a Corte, no panorama de uma democracia constitucional?

A legitimidade da jurisdição constitucional tem sido o centro de acalorados debates já há algum tempo, especialmente na literatura norte-americana. Em linhas gerais, os que a atacam sustentam-se em sua suposta falta de legitimação democrática, enquanto aqueles que a defendem, por sua vez, alegam tratar-se da consolidação de um fórum de princípios em que a verdadeira democracia - a substantiva - é resguardada.

Muito embora o tema represente uma linha de estudo de grande relevância, seu desenvolvimento pela maior parte dos estudiosos limita-se a apontar qual das instituições possui melhores condições de desempenhar a devida garantia e satisfação de direitos em dado sistema constitucional - as Cortes ou o Parlamento. O estudo do qual cuidará a pesquisa aqui desenvolvida propõe um passo adiante na análise, ou mesmo uma alteração de enfoque, de modo que instituições políticas sejam investigadas não como centros de poder autoritário detentores da última palavra na definição e implementação de direitos, mas antes membros coordenados de uma cadeia contributiva, visando a soluções de qualidade (potencialmente) aprimorada em modelos de diálogo institucional.

Para tanto, as teorias que brindam uma das instituições estatais com a legitimação última sobre a demarcação de direitos serão exploradas face às teorias construídas em torno da interação interinstitucional, que priorizam os efeitos da ação ou inação de uma instituição sobre a atuação da outra. Nesse caminho, será necessário que se desconstrua o arcabouço tradicional do constitucionalismo à luz da ideia de democracia constitucional, para uma análise não apenas da medida de poder das instituições estatais face à Constituição, mas do próprio papel da Constituição na realização da qualidade deliberativa no debate democrático.

Cortes e Parlamentos com suas respectivas dinâmicas, bem como sua dinâmica combinada, seguem no centro do tema a ser explorado. A perspectiva assumida, contudo, é essencialmente distinta daquela em que tem destaque a polarização política. O esforço argumentativo voltado à desconstrução da legitimidade democrática das Cortes ou à demonstração da insuficiência da atuação da legislatura dará lugar à análise de como (e se) modelos de diálogo institucional podem embasar teorias normativas satisfatórias para a justificação de modelos constitucionais democráticos e, em última instância, para a consecução de valores propugnados pelo Estado de Direito - cabendo inclusive questionar 
o papel central da Constituição no sistema político ${ }^{3}$. Cuida-se da compreensão da democracia constitucional à luz das teorias do diálogo, para uma releitura da dicotomia entre Cortes e Parlamentos pautada pela ideia de deliberação interativa e satisfação de direitos.

\section{I- O debate no Brasil}

Conclusões derivadas do debate acima resumido acabam por justificar disputas políticas entre instituições pelo poder da "última palavra” sobre o significado da Constituição. Na História do Brasil, uma tradição constitucional eminentemente autoritária, em conjunto com um sistema eleitoral cuja fragilidade esteve constantemente em evidência, esvaziava de sentido o questionamento acerca do caráter contramajoritário de seu Poder Judiciário, que mal conseguia impor limites reais aos outros Poderes.

Contudo, muito mudou no país desde a promulgação da Constituição Federal de 1988. A democracia está fundada em bases mais firmes, um modelo mais amplo de jurisdição constitucional passa a ser adotado e a proteção e implementação de direitos fundamentais tornam-se o novo norte a reger a ordem constitucional brasileira, conferindo ao Supremo Tribunal Federal papel de crescente destaque.

Debates acadêmicos no Brasil sobre o tema são relativamente recentes e tendem a seguir o modelo dicotômico, nos moldes até então descritos ${ }^{4}$. É grande o número de conflitos políticos e sociais que chegam à Corte Suprema nos dias atuais, bem como a agitação política em torno da sua atuação cada vez mais preponderante. Entretanto, o debate acadêmico nacional acerca da interação interinstitucional entre Cortes e Parlamento ainda caminha com timidez, na busca de solo fértil sobre o qual semear novas frentes de investigação. Como expoentes da academia desbravando esse caminho podem ser citados Conrado Hübner Mendes ${ }^{5}$ e Rodrigo Brandão ${ }^{6}$, cujas obras foram recém-lançadas e trazem contribuições de excelência inquestionável para a pesquisa.

\footnotetext{
${ }^{3}$ SCHAUER, Frederick. Judicial Supremacy and the Modest Constitution. California Law Review, v. 92, 2004.

${ }^{4}$ Elival da Silva Ramos é um dos expoentes na crítica da academia brasileira ao que se convencionou chamar "ativismo judicial” (SILVA RAMOS, Elival Da. Ativismo Judicial - Parâmetros Dogmáticos. São Paulo: Saraiva, 2010).

${ }^{5}$ MENDES, Conrado Hübner. Direitos Fundamentais, separação de poderes e deliberação. São Paulo: Saraiva, 2011.
} 
Exemplos de choques entre Cortes e Parlamento no Brasil são mais e mais frequentes, bem como uma atuação política generalizada que elege a disputa pelo poder em detrimento de outras instituições como a única via disponível. Exemplo dessa postura política combativa está no recente e emblemático caso das coligações partidárias e o preenchimento de vagas deixadas pelo licenciamento de titulares de mandato eletivo, que deu origem a conflito significativo entre o Supremo Tribunal Federal e o Congresso Nacional. Movimentar o debate acadêmico e ressaltar a necessidade de revisão - ou ao menos diversificação - dessa tendência são objetivos propostos pela pesquisa a ser desenvolvida.

Dentre os casos que devem ser destacados, encontra-se o da substituição por suplente na ocupação de vagas deixadas pelos titulares eleitos. Até o final do ano de 2010, no STF prevaleceu, por maioria, posição segundo a qual a vaga deixada pelo licenciamento de titular de mandato parlamentar deveria ser ocupada por suplente do mesmo partido, e não da coligação (MS 29.988). A decisão foi muito criticada e mal recebida pelo Poder Legislativo, que defendia tratar-se de questão a ser definida pela legislação específica e pelo próprio Parlamento. Tamanha foi a insatisfação, que em 2011, logo após a decisão mencionada, deu-se início no Congresso Nacional à tramitação da PEC 2/2011, dispondo expressamente caber ao suplente da coligação (e não do partido) a vaga deixada pelo licenciamento de titular.

Antes, contudo, de sua aprovação final, e diante da tensão que a celeuma vinha causando entre Judiciário e Parlamento, o STF reviu seu posicionamento e em abril de 2011 determinou que a vaga deixada pelo licenciamento de parlamentar deverá agora ser ocupada por suplente da coligação, e não mais do partido (MS 30.260 e MS 30.272). Além da Ministra Cármem Lúcia, os Ministros Joaquim Barbosa, Gilmar Mendes e Cezar Peluso modificaram a posição apresentada em dezembro de 2010 e aderiram ao entendimento de que as vagas de suplência devem ser definidas pelas coligações.

Muito há que ser investigado nessa mudança de posicionamento da corte. Não se pode negar a interação entre ela e o Legislativo, mas é válido explorar até que ponto o diálogo desenvolveu-se por vias de recursos vinculados à boa prática deliberativa. Averiguar também como e se o diálogo vem ocorrendo em demais casos envolvendo direitos constitucionalmente previstos enriquecerá sobremaneira a pesquisa ora empreendida.

${ }^{6}$ BRANDÃO, Rodrigo. Supremacia Judicial versus Diálogos Constitucionais. Rio de Janeiro: Lumen Juris, 2012. 


\section{II- Panorama acadêmico}

Teorias em favor da supremacia judicial são abundantes, como o são também aquelas que defendem a supremacia dos Parlamentos representativos. Os argumentos a serem analisados, em ambos os lados, provêm de autores de peso, quais sejam, John Hart Ely, Ronald Dworkin, Bruce Ackerman, John Rawls, Stephen Holmes, Owen Fiss, Robert Dahl, James Madison, Frank Michelman, Ian Shapiro, Jeremy Waldron, Oscar Vilhena Vieira, Rubens Beçak e Elival da Silva Ramos.

Bruce Ackerman ${ }^{7}$, a título de exemplo, defende a revisão judicial com base na divisão do constitucionalismo em dois níveis de produção do direito, a repercutir na hierarquia das normas - o ordinário e o extraordinário. No extraordinário, o Poder Constituinte funda juridicamente o Estado por meio de uma Constituição, enquanto no ordinário o legislador produz leis. A Corte Constitucional irá justamente controlar o Parlamento, no sentido de que ele obedeça aos rumos definidos em momento extraordinário. É o que Ackerman define como dualismo constitucional.

A Constituição, assim, institucionaliza uma vida política bipartida, separada em dois atos - a política constitucional e a política normal. A primeira ocorre em momentos especiais da história, em que o povo se mobiliza e toma decisões civicamente inspiradas no bem comum. Já a segunda consiste em política de interesses e barganha privados. A missão da revisão constitucional, pois, é prestar contas ao povo que se manifesta nos momentos constitucionais. Não há que se falar, para Ackerman, em dificuldade contramajoritária, mas tão somente de uma dificuldade intertemporal, uma vez que o processo de reforma (ou emenda), quando o povo decide mudar a constituição e a interpretação da corte, consome um esforço maior e mais demorado.

Adotando outra perspectiva estão autores que centram seu foco no diálogo entre instituições. Podem, contudo, instituições dialogarem entre si? Para os autores listados abaixo, esse fenômeno é realidade que não deve ser ignorada.

Alexander Bickel ${ }^{8}$ ocupa posição curiosa na teoria constitucional contemporânea. Muito embora tenha lançado questões de grande impacto, que influenciariam em grande medida a pesquisa da geração seguinte (a “dificuldade contramajoritária” é a principal

\footnotetext{
${ }^{7}$ ACKERMAN, Bruce. The Storrs Lectures: Discovering the Constitution. Yale Law Journal, v. 93, 1984.

${ }^{8}$ BICKEL, Alexander. Foreword: the passive virtues. Harvard Law Review, v.75, 1961.
} 
delas), suas próprias respostas a essas questões não receberam a mesma atenção. Para ele, as cortes possuem uma missão educacional que consiste em atuar como "professores de cidadania”, permitindo um colóquio entre os Poderes estatais e a sociedade toda vez que se recusem a prolatar uma decisão. Essa recusa geraria pressão para uma ação legislativa mais efetiva que qualquer ordem judicial inflexível.

Bickel estava convencido de que a plena consolidação de um princípio nas práticas de uma sociedade não deveria ser tarefa somente para a Corte. As decisões judiciais deveriam, portanto, surgir apenas como exceção, ao passo que o exercício do que ele chamou de "virtudes passivas" deveria representar a regra - um meio termo entre um autoritário ativismo judicial e a democracia.

Na mesma linha segue a doutrina de Cass Sunstein $^{9}$ e seu minimalismo, uma teoria acerca da jurisdição constitucional que se baseia na crença de que as Cortes não devem dizer mais do que o necessário para justificar o resultado proclamado, e assim deixar sem decisão a maior parte possível da celeuma. Enquanto Bickel prioriza uma análise dos momentos em que a Corte decide "não decidir”, Sunstein prefere focar os momentos em que a Corte de fato decide, mas decide na menor extensão possível.

Bickel e Sunstein são duas grandes referências na defesa de Cortes promovendo diálogos institucionais por meio de ações prudentes e minimalistas quando se trata de satisfazer direitos. Mais recentemente, autores diversos exploraram a possibilidade de estratégia oposta, mas imbuída do mesmo propósito de interação: no lugar do silêncio, Cortes mandariam “recados” e “conselhos” por meio de decisões articuladas e claras.

Neal Kumar Katyal ${ }^{10}$ publicou longo ensaio sobre o tema. Para ele, silêncio e inação não são as únicas alternativas para o diálogo, e cortes devem ser mais proativas em suas decisões. Para evitar interferências, juízes deveriam combinar decisões estreitas com conselhos de maior amplitude. Os aconselhamentos estariam presentes na obiter dicta da decisão, e não em sua ratio, de modo que possuiriam mais flexibilidade e nenhum efeito vinculante, fornecendo direcionamentos de maneira mais eficiente do que aquela adotada pelo minimalismo.

Barry Friedman ${ }^{11}$ oferece contribuição significativa para a discussão ao definir a interpretação constitucional como uma espécie de diálogo. Ele identifica um paradoxo entre dois objetivos que são normalmente esperados da democracia: que os Poderes estatais

\footnotetext{
${ }^{9}$ SUNSTEIN, Cass. The Partial Constitution. Cambridge: Harvard University Press, 1998.

${ }^{10}$ KATYAL, Neal Kumar. Justices as Advicegivers. Stanford Law Review, v. 50, 1997.

${ }^{11}$ FRIEDMAN, Barry. Dialogue and Judicial Review. Michigan Law Review, v. 91, 1993 e The Politics of Judicial review. Texas Law Review, v. 84, n. 2, 2005.
} 
espelhem aspirações populares e que demonstrem perfil de liderança na busca por alternativas aprimoradas na proteção de direitos. Consequentemente, instituições políticas tendem a aproximar-se da opinião pública, mas logo se distanciam dela, alternadamente. Daí a conclusão de que a legislação nem sempre provirá de substrato majoritário, e de que a jurisdição exercida pelas Cortes nem sempre será contramajoritária - ela raramente o será, pois exerce uma missão única, que não pode ser explicada em termos da oposição maioritária x minoritária.

O debate canadense sobre o tema do diálogo foi inaugurado por artigo de Peter Hogg e Alison Bushell ${ }^{12}$ em 1997. Eles analisaram todos os casos em que a Suprema Corte canadense declarou a inconstitucionalidade de legislação promulgada pelo Parlamento, e descobriram que a casa de legisladores reagiu por meio de ação legislativa em grande parte desses casos. A conclusão a que chegaram foi de que a jurisdição constitucional havia dado início a um debate público de qualidade, que não teria ocorrido senão por meio dessa iniciativa. Kent Roach ${ }^{13}$ seguiu no encalço do estudo mencionado defendendo que a supremacia legislativa ou mesmo a supremacia judicial minariam as chances de se construir uma democracia de bases críticas.

A canadense Janet Hiebert ${ }^{14}$, por sua vez, aderiu ao debate para criticar a noção desenvolvida por Hogg e Bushell de que as Cortes seriam as condutoras da interação institucional, sugerindo ao revés uma responsabilidade igualmente distribuída no controle da integridade desse diálogo - o Parlamento, nesses termos, seria tão capacitado quanto os Tribunais. E trata-se apenas de um reduzido panorama da recente produção de autores canadenses, que vêm alimentando uma rica pesquisa sobre essas e demais questões correlatas e simbolizam a disseminação da cultura constitucional entre as democracias contemporâneas.

Assumindo, pois, a existência de interlocução entre instituições, outras questões relevantes despontam: a revisão judicial faz o Parlamento abdicar por completo de seu papel de intérprete constitucional, ou exatamente o contrário se passa? Sem revisão constitucional, o Parlamento sentir-se-ia mais pressionado a oferecer uma interpretação

\footnotetext{
${ }^{12}$ HOGG, Peter; BUSHELL, Alison. The Charter Dialogue Between Courts and Legislatures (Or Perhaps the Charter of Rights Isnt't Such a Bad Thing After All). Osgoode Hall Law Journal, v. 35, n. 1, 1997.

${ }^{13}$ ROACH, Kent. The Supreme Court on Trial: Judicial Activism or Democratic Dialogue. Irwin Law, 2001 e Sharpening the Dialogue Debate. Osgoode Hall Law Journal, v. 45, 2007.

${ }^{14}$ HIEBERT, Janet. Limiting rights: the dilema of judicial review. Québec: McGill-Queens University Press, 1996 e Charter conflicts: what is Parliament`s role? Québec: McGill-Queens University Press, 2004.
} 
constitucional adequada? Afinal, são essas questões que podem ser respondidas em um plano abstrato?

Com tese de doutoramento publicada há pouco tempo, Conrado Hübner Mendes oferece grande - senão uma das maiores - contribuição do debate brasileiro para o tema do diálogo institucional na legitimação da jurisdição constitucional ${ }^{15}$. Em linhas gerais, defende ele uma perspectiva do diálogo em que Corte e Parlamento não se colocam de maneira excludente. Embora admita que a definição de papéis específicos seja importante no desenho institucional, o argumento epistêmico pela supremacia de qualquer instituição é indesejável. A interação deliberativa entre as instituições e a busca pelas melhores razões públicas levariam à minimização dos erros, potencializando a capacidade da democracia sem negar a falibilidade das instituições.

Pode-se afirmar que teorias do diálogo, nos moldes do disposto até então, demonstram a insuficiência de teorias da última palavra? Em caso positivo, dentro da estrutura institucional já existente, essas teorias oferecem uma resposta autônoma e satisfatória para substituir a solução da última palavra? Como, portanto, combinar a provisoriedade das decisões com a continuidade da política?

Hübner Mendes, no plano do diálogo interinstitucional, defende que só será satisfatória uma solução que conjugue no processo político decisório as matrizes da última palavra e do diálogo, por meio da introdução das noções de "rodada procedimental” e de “última palavra provisória”. Toda constituição irá prever caminhos institucionais para a consecução de projetos coletivos e para a solução de conflitos, com pontos de partida, estágios intermediários e um ponto final. Esse ponto será final, contudo, apenas dentro de uma rodada, que sempre poderá ser recomeçada indefinidamente ${ }^{16}$.

Nessa altura da pesquisa, não se deve perder de vista o fato de que as concepções variadas de legitimidade a informarem uma dada cultura política acabam por influenciar a natureza da interação institucional. Dizer que não há uma última palavra, mas um diálogo permanente entre instituições políticas certamente ameniza tanto as objeções democráticas à revisão judicial quanto as objeções à lógica procedimentalista da maioria por trás do funcionamento do parlamento, à medida que insere um senso de continuidade na discussão. Mas o que dizer da legitimidade da interferência de diferentes instituições, em momentos distintos, nesse processo político? Como justificar os custos que essas interferências decisórias continuarão impondo sobre a vontade democrática?

\footnotetext{
${ }^{15}$ MENDES, 2011.

${ }^{16}$ MENDES, 2011, p. 170.
} 
Não há como explorar as questões acima sem se passar pela concepção da separação de poderes.

Hobbes marca o advento do Estado soberano moderno defendendo a necessidade de um último e indivisível Poder soberano que combata os perigos do vácuo político ${ }^{17}$. Marca também a tradição política da modernidade a Constituição americana, representando o momento em que o mecanismo de freios e contrapesos tem origem mais clara e inaugura uma nova divisão funcional dos poderes, com o poder controlando o próprio poder. Conrado Hübner Mendes relembra que referida divisão funcional dos poderes ainda não estava presente em Montesquieu, que apenas associa a separação de poderes a uma hierarquia estamental. Os Federalistas é que teriam dado origem a uma "maquinaria governamental que não se conecta diretamente com a suposição de uma sociedade dividida rigidamente" 18 .

Na mesma esteira, Rubens Beçak ${ }^{19}$ ressalta que a teoria de Montesquieu aliou a identificação de funções estatais à recomendação de que não fossem atribuídas a mais de um Poder cada uma delas, de modo que cada Poder desempenhasse sua função sem invadir a esfera alheia. Se num primeiro momento, frisa o autor, a divisão estanque parece de ordem absoluta, logo fica evidente tratar-se da atividade primeira e preferencial de cada Poder. Se os Poderes estatais exercem funções que, em tese, não lhes são próprias, o fazem como atribuições necessárias à consecução de suas próprias tarefas.

Assim é que, segundo Beçak, a concepção de que os Poderes exerceriam funções restritas a suas denominações teria sofrido inegável abalo com o advento da teoria dos checks and balances, é dizer, com a adaptação norte-americana da Teoria da Separação de Poderes de Montesquieu.

Pois bem. Dentro dessa adaptação empreendida pela teoria dos Federalistas, constata-se que não tinha espaço a necessidade de identificação do locus do Poder soberano do ponto de vista interno ${ }^{20}$. As democracias contemporâneas incorporaram a noção de soberania e a transferiram ao povo. Organizaram-se, contudo, em uma complexa estrutura de freios e contrapesos, diluindo a noção unívoca e centralizada de soberania

\footnotetext{
${ }^{17}$ HOBBES, Thomas. O Leviatã. Org. Richard Tuck. Trad. de João Paulo Monteiro e Maria Beatriz Nizza da Silva. São Paulo: Martins Fontes, 2003.

${ }^{18}$ MENDES, 2011, p. 177

${ }^{19}$ BEÇAK, Rubens. A Hipertrofia do Executivo Brasileiro: o impacto da constituição de 1988. São Paulo: Própria, 2007.

${ }^{20}$ ARAÚJO, Cícero. Representação, retrato e drama. Lua Nova, v. 67, 2006.
} 
interna $^{21}$. Como essa percepção de soberania reflete na atuação dos Poderes é ponto de grande significado.

Outro ponto pouco explorado pela doutrina é a separação de poderes em face do papel da deliberação na democracia. É comum a assunção de que Poderes não deliberam entre si, mas apenas se controlam. A interação na separação de poderes, contudo, é inevitável, e instituições apresentam razões para suas decisões. Em que medida elas devem ser levadas em conta na reação de outras instituições? Pode-se esperar que a acomodação de funções cambiantes entre os Poderes seja influenciada por uma cultura de deliberação, e não pura distribuição de forças? Quem deteria, enfim, a última palavra provisória? Na instigante obra de Conrado Hübner Mendes, o autor conclui que “a interação deliberativa é um ganho; a interação puramente adversarial, se não chega a ser uma perda, desperdiça seu potencial epistêmico"22.

\section{III- A pesquisa}

Procurando aprofundar as questões acima lançadas na contextualização do debate que se pretende focar, a pesquisa virá dividida em três capítulos.

O primeiro voltará às origens históricas da jurisdição constitucional no cenário político-social americano, na tentativa de entender as influências externas e internas (ao mundo jurídico) operando no processo de consolidação do modelo de controle de constitucionalidade no sistema constitucional dos Estados Unidos. Lançará também análise acerca da ambivalência política do debate sobre jurisdição constitucional, para introduzir, no contexto das teorias comportamentais, o modelo "neoinstitucional”.

O segundo capítulo, por sua vez, irá explorar as bases da argumentação contra a revisão judicial - iniciando na voz do expoente Jeremy Waldron -, passando às evoluções teóricas que juristas de peso vieram a construir sobre a semente lançada por Waldron. O que irá se observar, contudo, é que o aprofundamento e as tentativas de avançar em seus passos acabam por encaminhar os autores em direções menos extremistas e mais ciosas da necessidade de se alterar o enfoque até então adotado pelo chamado constitucionalismo. O capítulo segue com um apanhado geral das críticas centrais à ideia de supremacia judicial, enunciadas por Conrado Hübner Mendes.

${ }^{21}$ ARAÚJO, 2006.

${ }^{22}$ MENDES, 2011, p. 211. 
Com o intuito de retratar o outro lado das trincheiras acadêmicas, a segunda parte do segundo capítulo virá com a compilação dos principais argumentos contra o que se denomina supremacia legislativa, não sem antes dedicar breves parágrafos à renovada visão da doutrina (minoritária, por certo) sobre a revisão judicial na Inglaterra.

Tem-se, por fim, no terceiro e último capítulo a análise das teorias que focam o diálogo entre as instituições políticas e judiciais dentro do sistema de governo democrático, com a investigação das possíveis formas de convivência do desacordo sobre direitos com instituições legítimas atuando em nome da razão pública e da lógica deliberativa. Em sua parte final, vale mencionar, a pesquisa lança luz sobre a experiência brasileira e investiga os pressupostos dialógicos na prática institucional do país - a interação entre o Supremo Tribunal Federal e o Congresso Nacional ganha destaque. 


\section{- CAPÍTULO I - \\ DAS ORIGENS NORTE-AMERICANAS \\ DA JURISDIÇÃO CONSTITUCIONAL AO MODELO \\ “NEOINSTITUCIONAL"}

\section{Cresce o poder da vontade popular - é hora de temperar a democracia}

Voltando às origens estadunidenses do chamado judicial review, interessante notar que, na História política dos EUA, o Judiciário vai angariando poder à medida que cresce a influência popular sobre as legislaturas locais ${ }^{23}$. Para reagir às ameaças que as conquistas populares começam a representar a partir da Guerra da Independência contra a Inglaterra tanto no campo político como no material -, uma minoria economicamente privilegiada concentra esforços no desenvolvimento e aplicação da ideia fundadora do controle judicial de constitucionalidade, em fenômeno que será analisado nas linhas abaixo.

Remonta à época colonial o costume nos EUA de reuniões da população em geral em pequenas assembleias municipais - as town meetings -, que logo evoluiriam para as county conventions, de modo que as legislaturas eram observadas de perto por aqueles que representavam ${ }^{24}$. Essa característica política contribuiu para uma grande insatisfação popular relacionada à pesada carga tributária então imposta. É que cada Estado da Confederação americana era responsável por seus próprios débitos durante a Guerra da Independência contra a Inglaterra. Assim, segundo Gargarella, a pressão dos ingleses para receber seus pagamentos dos grandes proprietários e comerciantes os levava a forçar que seus próprios devedores - pequenos fazendeiros e camponeses (os yeomen) - saldassem

${ }^{23}$ GARGARELLA, Roberto. La Justicia Frente ao Gobierno: Sobre el Carácter Contramayoritário del Poder Judicial. Barcelona: Editorial Ariel S.A., 1996, p. 17.

${ }^{24}$ GARGARELLA, 1996, pp. 18-19. 
suas dívidas para com eles, além de aumentarem a tributação como um todo sobre toda a população.

O movimento de reação dessa nova classe de fazendeiros e comerciantes foi inicialmente pacífico, iniciado pela introdução do tema para discussão nas town meetings e nas county conventions. Eles desejavam a emissão de papel moeda de curso forçado, o que desagradava imensamente à elite mercantil, já que permitiria aos pequenos comerciantes pagar compras anteriores com dinheiro inflacionado, repassando, pois, uma parte dos débitos do pós-guerra à própria elite ${ }^{25}$. Como não houvesse apoio à emissão de papel moeda por parte das legislaturas dos Estados, o movimento assumiu então caráter violento, com o fechamento de Tribunais e boicote à arrecadação de tributos em diversos Estados. Nas palavras de Szatmary:

(...) por meio de petições da Town (meetings) e County (conventions), yeomen propuseram soluções que neutralizassem as demandas dos credores. Papel moeda tornou-se então a sugestão mais popular. Em Massachussetts, mais da metade das petições pediam especificamente por papel moeda ${ }^{26}$.

Rebeliões espalhadas pelo país evidenciaram à elite dirigente a necessidade de um governo mais centralizado, com poderes que alcançassem as localidades ${ }^{27}$. Diante da ameaça de novos levantes, as legislaturas locais foram compelidas, como argumenta Gargarella, a espelhar tendências populares nas novas medidas políticas, o que levava, agora, medo agora à classe dominante.

A grande guinada ideológica na construção da História política americana, como hoje a conhecemos, tem aí seu início - de um ideal a ser perseguido indiscriminadamente, a democracia ganha inimigos que, se não querem extingui-la de vez, desejam ao menos limitá-la, como bem ressalta Ekirch $\mathrm{Jr}^{28}$. Tanto é assim que os famosos framers, na fundação da República americana, em 1787, estabeleceram como meta um governo pelo povo, que protegesse tanto o povo face ao Estado quanto o Estado face ao povo ${ }^{29}$.

\footnotetext{
${ }^{25}$ SZATMARY, David P. Shay`s Rebellion: the Making of an Agrarian Insurrection. United States of America: The University of Massachusetts Press, 1980.

${ }^{26}$ SZATMARY, 1980, p. 40, tradução minha.

27 SZATMARY, 1980, pp. 37-38

${ }^{28}$ EKIRCH Jr. e ARTHUR A. Democracia Americana: Teoria e Prática. Trad. de Álvaro Cabral, Constantino Paleologo. Rio de Janeiro: Zahar, 1965.

${ }^{29}$ BURNS, James MacGregor. Packing the Court: The Rise of Judicial Power and the Coming Crisis of the Supreme Court. United States of America: Penguin Books, 2009.
} 


\section{A influência federalista no desenho da República americana}

O medo de que o novo governo central fortalecido fosse dominado por maiorias populares transitórias e oportunistas levou alguns dos Constituintes americanos a buscar arranjos institucionais na conformação do Estado que prevenissem a opressão pela regra da

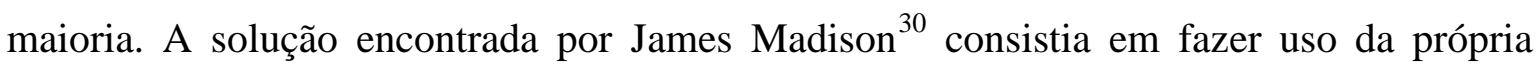
natureza fragmentada do povo na forma de "facções", é dizer, divisões baseadas na geografia da terra, na religião, e, principalmente, nas classes sociais determinadas pela distribuição desigual de propriedade. Divisões essas que, nos termos utilizados por Madison nos ensaios Federalistas, estão costuradas na própria natureza humana.

E se era certo que o choque desregrado das referidas facções dentre a estirpe humana levaria a um estado de anarquia, o predomínio de uma única delas, por outro lado, levaria ao poderio ilimitado de uma maioria, em sacrifício aos mais fracos. O que asseguraria, na concepção de Madison, o equilíbrio do sistema como um todo seria a grande variedade de partes e interesses espalhados no vasto território nacional, garantindo que o governo central não fosse dominado nem por uma reduzida elite e nem pela massa popular.

Os Federalistas, bem ao certo, partiam da premissa lockiana acerca da existência de verdade autoevidentes que apenas chegavam ao conhecimento de alguns poucos - os que possuíam tempo e capacidade para tanto. Assim é que, politicamente, a discussão e representação adequadas dos interesses da sociedade como um todo caberiam a alguns poucos homens, encerrando posicionamento altamente elitista ${ }^{31}$.

Para Madison, quanto maior o número de membros em uma assembleia legislativa, menor a quantidade de homens que de fato conduzem suas ações, bem como maior a ascendência da paixão sobre a razão, independente da competência dos homens que a componham. Maior será, também, a proporção deles com informação limitada e pouca capacitação $^{32}$. O governo de todos era assim desacreditado em nome de um regime centralizado de governo, livre dos perigos do facciosismo. Confira-se:

\footnotetext{
${ }^{30}$ MADISON, James; HAMILTON, Alexander; JAY, John. Os Artigos Federalistas (1787-1788). Trad. De Maria Luiza X. de A. Borges. Rio de Janeiro: Nova Fronteira, 1993.

${ }^{31}$ GARGARELLA, Roberto. La Revision Judicial y la Dificil Relacion Democracia-Derechos, Fundamentos y Alcances de Control Judicial de Constitucionalidad: Investigacion Colectiva del Centro de Estudios Institucionales de Buenos Aires. Madrid: Centro de Estudios Constitucionales, 1991.

${ }^{32}$ MADISON; HAMILTON; JAY, 1993.
} 
Entre as inúmeras vantagens prometidas por uma União bem construída, nenhuma merece ser mais cuidadosamente elucidada que sua tendência a deter e controlar a violência e o facciosismo. São estes perigosos vícios os que mais assustam o simpatizante dos governos populares. Ele não deixará, portanto, de dar justo valor a todo plano que, sem violar os princípios que acata, forneça um remédio apropriado para o mal. Instabilidade, injustiça e confusão introduzidas nos conselhos públicos foram doenças mortais, que fizeram perecer governos populares por toda parte, e continuam sendo os tópicos favoritos e frutíferos a inspirar as mais capciosas arengas dos adversários da liberdade ${ }^{33}$.

Uma vez que a divisão humana em facções, como já dito mais acima, estaria ligada à própria natureza do ser humano, a única maneira de remediar o facciosismo seria controlando seus efeitos. O grande perigo, na visão de Madison, estaria num governo popular por uma facção constituída de uma maioria, em que lhe seria permitido sacrificar o bem público em nome de paixões ou interesse dominantes.

Para impedir que assim ocorresse, dois seriam os meios: evitar que uma mesma paixão dominasse uma maioria ao mesmo tempo, ou, caso esse fosse o cenário, incapacitála de executar esquemas de opressão ${ }^{34}$. O primeiro meio seria impraticável, razão pela qual democracias puras não seriam eficazes contra os malefícios da facção, já que a própria forma de governo propiciaria a comunicação e o ajuste de paixões e interesses, sem que houvesse nada controlando a tendência a sacrificar a parte mais fraca ${ }^{35}$. A solução, portanto, estaria na segunda opção, que só o modelo de governo caracterizado como República lograria obter.

A característica fundamental da República seria a entrega do governo a um grupo de pessoas escolhidas entre os cidadãos, para virarem então representantes do povo - os quais atuariam movidos pela aspiração ao bem público de modo mais satisfatório que o próprio povo ${ }^{36}$. Aqui já se observa uma distinção que mais adiante na História se faria entre democracia direta e democracia representativa. Robert Dahl defende que Madison foi

\footnotetext{
33 MADISON; HAMILTON; JAY, 1993, p. 133.

${ }^{34}$ MADISON; HAMILTON; JAY, 1993, p. 136.

${ }^{35}$ MADISON; HAMILTON; JAY, 1993, p. 137. Confira-se: "uma paixão ou interesse comum contamina, em quase todos os casos, a maioria do todo; a própria forma de governo propicia a comunicação e o ajuste; e nada controla as tendências a sacrificar a parte mais fraca ou um indivíduo inofensivo. Assim é que tais democracias sempre ofereceram espetáculos de turbulência e luta; sempre se mostraram incompatíveis com a segurança pessoal ou com os direitos de propriedade; e tiveram, em geral, vidas tão breves quanto violentamente interrompidas”.

${ }^{36}$ MADISON; HAMILTON; JAY, 1993, p. 137. Confira-se: “(as opiniões do povo) que são filtradas por uma assembleia escolhida de cidadãos, cuja sabedoria pode melhor discernir o verdadeiro interesse de seu país e cujo patriotismo e amor à justiça serão menos propensos a sacrificá-lo a considerações temporárias ou parciais. Sob tal regulação, é bem provável que a voz pública, manifestada pelos representantes do povo, seja mais consoante com o bem público que se manifesta pelo próprio povo, convocado para esse fim”.
} 
influenciado por uma tradição republicana mais inclinada em direção à aristocracia, ao sufrágio limitado, à preocupação com os direitos de propriedade e ao medo de um governo dominado por uma ampla base popular ${ }^{37}$.

Como bem se observa, o apoio à democracia representativa era baseado exatamente no afastamento do centro de poder em relação ao próprio povo, diferentemente do que se observa nos dias atuais, quando vozes ressurgem na ciência política norte-americana imbuídas do propósito de recuperar a legitimidade da forma representativa de democracia, amparando-se para tanto na preservação da qualidade da vontade genuinamente popular em virtude da perenidade inerente à representação ${ }^{38}$.

\section{A Convenção de Filadélfia e o Poder Judiciário}

Outra questão de peso a ser ponderada pelos delegados na Convenção de Filadélfia, no verão de 1787, era aquela referente à Legislatura federal face às estaduais, tema em relação ao qual James Madison considerava absolutamente necessário, para a obtenção de um sistema perfeito de governo centralizado, o poder de veto do Congresso Federal sobre as leis estaduais ${ }^{39}$. Essa proposição, contudo, recebeu forte oposição na Convenção, de

\footnotetext{
${ }^{37}$ DAHL, Robert A. How Democratic is the American Constitution? 2a Ed. New Haven \& London: Yale University Press, 2003.

${ }^{38}$ Na ciência política, Nadia Urbinati constrói uma teoria da democracia representativa em torno da ideia de continuidade histórica e da política como uma série cíclica de decisões. Seu foco está centrado na questão da representação na democracia, mas o argumento pode ser aplicado também na relativização da última palavra definitiva em processos de decisão política sobre direitos. O que a autora denomina de teoria da representação política invalida, pois, a noção de que a sociedade é a mera soma de indivíduos dissociados que competem entre si e se unem apenas para votar e agregar preferências, por meio de cálculos instrumentais. Resta aqui plenamente afastada aquela concepção da democracia como "uma multidão numérica de unidades singulares ou associadas forçadas a delegar seu poder pela simples razão de que uma multidão não pode ter uma vontade, não pode exercer nenhum poder ou ser um governo" (URBINATI, Nadia. Representative Democracy: Principles and Genealogy. Chicago: University of Chicago Press, 2008, p. 210, tradução minha). Uma real democracia reflete uma malha intrincada de significados e interpretações das crenças dos cidadãos sobre quais são seus interesses, interesses esses diferenciados e que variam ao longo da vida real das pessoas. Daí a conclusão de que a democracia é única, uma vez que encontra nas diferenças a força para a união. Outro aspecto essencial captado pela cientista política da Universidade de Columbia é a diferença nos tipos de votos computados em uma democracia direta e em uma democracia representativa. Enquanto na democracia direta os votos recaem sobre questões isoladas, não havendo ali um processo de construção de opiniões baseado em uma continuidade histórica, na democracia representativa, por outro lado, tem-se um regime de tempo, com votos em prol de um candidato, refletindo a atratividade de uma plataforma política ou um conjunto de demandas e ideias ao longo do tempo. O trunfo da democracia representativa, portanto, seria sua capacidade de revelar o miraculoso trabalho de opiniões e narrativas ideológicas de modo tal que a democracia direta não é capaz, pois essa última faz de cada voto um ato único, um evento absoluto, transformando a política em uma série única de decisões.

${ }^{39}$ BENTON, Wilbourn E. 1787: Drafting the Constitution, vol. II. United States of America: Texas A\&M University Press, 1986, p. 1459.
} 
modo que os Constituintes optaram por adotar a cláusula da supremacia constitucional - a Constituição Federal seria a lei suprema de todo o território nacional, vinculando todos os demais Estados da Confederação.

A medida pareceu, em certa medida, implicar a adoção da revisão judicial das leis estatais por Tribunais Federais. No entanto, interessante notar que esse não foi um ponto debatido formalmente ou decidido de forma expressa na própria Convenção ${ }^{40}$, assim como tampouco foi objeto de decisão expressa a questão da atuação do Poder Judiciário sobre as leis federais, de seu turno.

Em inúmeras ocasiões durante a convenção, Madison e alguns outros Constituintes propuseram a união do Presidente da nação e dos Ministros da Suprema Corte sob um “Conselho de Revisão”, com autoridade para examinar todos os atos do Congresso e vetar leis inconstitucionais ${ }^{41}$. Opositores alegaram que isso significaria uma mistura inadequada de poderes, de modo que a discussão não foi adiante e a sugestão não entrou nas provisões constitucionais finais.

Apesar de reconhecer que abusos poderiam levar à concentração de todos os poderes de governo nas mesmas mãos, sendo essencial a existência de Tribunais que declarassem nulos os atos contrários ao sentido da Constituição ${ }^{42}$, James Madison não chegou ao extremo de declarar um Poder acima do outro. Sua visão teórica atribuía ao Judiciário a função de conferir as feições finais à legislação, mas apenas como uma simples etapa do processo de produção legislativa - o que não significava, em suas palavras, a Suprema Corte como órgão soberano face ao Legislativo ${ }^{43}$.

Nos ensaios Federalistas, a defesa principal da interferência dos Tribunais nas medidas passadas pelas legislaturas foi oferecida por Alexander Hamilton, cuja visão inicial restringia tal interferência tão-somente aos esporádicos excessos cometidos por maiorias legislativas ${ }^{44}$.

Mesmo depois de promulgada a Constituição dos EUA, o debate acerca da intenção dos delegados americanos na Convenção de Filadélfia não arrefecia. Teriam apenas assumido a supremacia judicial a ser exercida pela Suprema Corte? A intenção dos fundadores foi incontáveis vezes sondada por aqueles que afirmavam terem encontrado,

\footnotetext{
${ }^{40}$ BURNS, 2009, p. 13.

${ }^{41}$ Resolution, May 29, 1787. In: BENTON, vol. I, p. 792.

42 MADISON; HAMILTON; JAY, 1993, Federalista LXXVIII, p. 480.

${ }^{43}$ Carta de 24 de outubro de 1787 de Madison para Thomas Jefferson in Madison, Papers, Robert A. Rutland et al., eds. University of Chicago Press, 1991, vol. 10, pp. 206-219.

${ }^{44}$ Cf. WHITTINGTON, Keith E. An "indispensable Feature”? Constitutionalism and judicial review. NYU Journal of Legislation and Public Policy, 2002-2003.
} 
nos documentos da Convenção, menções espalhadas aqui e ali ao poder judicial sobre a legislação emanada pelos parlamentares. Defendiam, pois, que os Constituintes simplesmente assumiram como implícita a autoridade absoluta da Suprema Corte sobre a Constituição - que a expressão “jurisdição constitucional” abarcaria não somente controle sobre medidas manifestamente inconstitucionais ou intromissões indevidas na esfera de atuação do Judiciário, mas monopólio sobre a interpretação constitucional na forma de poder ilimitado de anular atos emanados pelos representantes do povo ${ }^{45}$.

James Kent ${ }^{46}$, jurista americano com produção acadêmica que remonta à época da Convenção, imbuído do espírito elitista já demonstrado por Federalistas de expressão, como referido mais acima, defendeu que os fundadores haviam organizado as Cortes americanas objetivando livrá-las das influências malévolas das facções, fazendo do Judiciário o baluarte em excelência do governo contra o povo unido em maiorias desregradas.

Mais de um século depois, o historiador econômico Charles Beard ${ }^{47}$ argumentava $^{2}$ que a intenção dos fundadores havia sido frustrar leis populares que atentassem contra direitos de propriedade privada, à medida que haviam conferido poder a um Judiciário desprovido de contato direto com o eleitorado popular.

Não existe, entretanto, prova definitiva acerca de intenções de tal natureza no texto constitucional ou mesmo nos escritos da Convenção. Na ausência de provas, costuma ser dito que os antigos apelos coloniais às Cortes americanas para que anulassem atos do Parlamento britânico seria indício da intenção que dominava o espírito dos Constituintes, independentemente de tratar-se de instituto utilizado na luta pela independência ${ }^{48}$.

Em que pese toda a polêmica em torno da questão, deve-se ressaltar que a Constituição americana de 1787 não previu explicitamente o poder do Judiciário de rever as decisões políticas dos demais Poderes. A adoção do instituto da revisão judicial só seria estabelecida quinze anos depois, no julgamento de Marbury v. Madison pela Suprema Corte americana.

\footnotetext{
${ }^{45}$ BURNS, 2009, p. 15.

${ }^{46}$ KENT, James. An introductory Lecture to a Course of Law Lectures in Charles Hyneman and Donald S. Lutz, eds. American Political Writing During the Founding Era, vol. II: Liberty Press, 1983.

${ }^{47}$ BEARD, Charles. The Supreme Court and the Constitution. Reprinted by Paisley Press, 1938.

${ }^{48}$ BURNS, 2009, p. 15.
} 


\section{Contextualizando Marbury v. Madison no cenário político de então}

Antes de entender o que significou a decisão em Marbury v. Madison para o constitucionalismo e para o processo constitucional no âmbito das Cortes, interessante entender os bastidores políticos que dominavam o cenário norte-americano de então, cuja nuances determinaram o alcance das práticas institucionais a serem consolidadas.

Pouco depois de uma década após estabelecido o novo governo central, a natureza menos partidária da Suprema Corte americana de George Washington se transformava em um centro de controvérsia político-partidária. A opinião pública ressaltava o perigo no abuso do poder judicial - ainda mais um parcial como aquele -, o que colocava em cheque a legitimidade do Poder Judiciário em sua atuação ${ }^{49}$. James Madison, ciente dessa situação de descrédito e fragilidade, saiu em 1800 na defesa de sua “Resolução de Virginia”, para reafirmar que se o processo legislativo fazia da Suprema Corte a detentora da última palavra em matérias constitucionais dentro da esfera governamental, isso não fazia dela a detentora da última palavra por excelência - esta ainda pertencia ao povo: “A autoridade de constituições sobre governos, e da soberania do povo sobre constituições, são verdades que se deve ter em mente o tempo todo; e talvez nunca tenham sido tão necessárias como no presente" 50 .

A tensão política alcançou seu ápice nas eleições de 1800, com uma derrota ressonante para os "federalistas" e um triunfo para os "republicanos" de então. Politicamente, a era Federalista chegava ao fim, mas Adams e seus parlamentares correligionários não deixariam a cena sem antes tentar garantir que o Judiciário estivesse repleto de aliados para o século que viria.

O Ato Judiciário de 1801 transformou-se em lei em 13 de fevereiro de 1801, três semanas antes que Thomas Jefferson fosse empossado como o novo Presidente da República. $\mathrm{O}$ ato colocou à disposição do então Presidente Adams dezesseis novas vagas de "circuit court judges". Os republicanos, revoltados, apelidaram a medida de "lei dos juízes da meia-noite”, enquanto Adams trabalhava sem trégua para distribuir indicações a federalistas leais e o congresso corria para confirmá-los ${ }^{51}$.

\footnotetext{
${ }^{49}$ BURNS, 2009, p. 23.

50 "The authority of constitutions over governments, and of sovereignty of the people over constitutions, are truths which are at all times necessary to be kept in mind; and at no time perhaps more necessary than the present” (BURNS, 2009, p. 23, tradução minha).

51 TURNER, Kathryn. The Midnight Judges. University of Pennsylvania Law Review, v. 109, n. 4, 1961.
} 
Quatro dias antes que o mandato de Adams chegasse ao fim, foi criado um novo Tribunal para a nova capital da nação, o Distrito de Colúmbia, com três vagas de juízes e diversos outros funcionários ligados à corte, dentre eles juízes de paz. Para preencher essas vagas, Adams e seu Secretário de Estado, John Marshall, vararam a noite anterior à posse de Jefferson, assinando e apondo selos a essas comissões. Não houve, contudo, tempo suficiente para entregar todas aos indicados antes que Jefferson virasse Presidente, e um que deixou de receber a sua foi o proeminente federalista William Marbury ${ }^{52}$.

O dia chegou em que Jefferson, o empossado, ficou cara a cara com Marshall, enquanto o agora novo presidente da Suprema Corte americana ${ }^{53}$ colhia o juramento correspondente do novo Presidente dos EUA. Afirmando que eram todos republicanos, e todos federalistas - tratava-se de simples designações distintas que simbolizavam "nossa ligação com a União e com o governo representativo" ${ }^{44}$-, Jefferson assumiu tom conciliatório e pacificador, preferindo relevar o papel preponderante que Marshall tivera na nomeação dos juízes da meia-noite.

John Marshall era considerado um federalista moderado, cioso dos princípios basilares do poder nacional federalizado, mas ainda assim avesso a extremos partidários. Assim como George Washington, Marshall acompanhou com pesar o enfraquecimento da União enquanto os Estados se digladiavam em busca de interesses próprios nas disputas revolucionárias. O que Marshall aprendeu a valorizar - estabilidade legal, ordem social e progresso econômico -, vinha sendo ameaçado por governos estaduais fracos e incompetentes. Quando serviu como parlamentar na Assembleia Legislativa da Virginia, convenceu-se de que o remédio estaria em um eficiente e organizado governo centralizado ${ }^{55}$.

Defendeu, portanto, a Constituição Federal face à legislação passada pelos Estados. E quando antifederalistas expunham o medo de que as legislaturas estaduais fossem

\footnotetext{
52 TURNER, p. 522.

${ }^{53}$ A nomeação de John Marshall à Suprema Corte americana é um exemplo espetacular do homem certo, no lugar certo e na hora certa. O Ministro Oliver Ellsworth, então presidente da corte, havia sido enviado numa missão de paz à Europa em novembro de 1799. Adoeceu na França, de onde enviou sua carta de demissão à Adams, que a recebeu em dezembro de 1800. Caso tivesse esperado para demitir-se ao voltar aos EUA em março de 1801, o responsável pela escolha de seu sucessor teria sido Jefferson, o que possivelmente mudaria o curso dos acontecimentos seguintes (BURNS, 2009, pp 25-26).

54 "First Inaugural Address", 04 de março de 1801 in Jefferson, Papers, Julian P. Boyd, ed. Princeton University Press, 1950, vol. 33, pp. 149-150, tradução minha.

55 “To a Freeholder”, Virginia Herald (Fredericksburg), 02 de outubro de 1798 in Marshall, Papers, Herbert A. Johnson, ed. University of North Carolina Press, 1974-2006, vol. 10.
} 
engolidas pelo Congresso Federal, Marshall apontava a jurisdição constitucional da Suprema Corte como o antídoto para esse mal ${ }^{56}$.

Enquanto o Poder Judiciário parecia ser o único reduto em que ainda despontavam maiorias federalistas, Legislativo e Executivo, dominados por republicanos, nas palavras do então Senador John Breckinridge, de Kentucky, clamavam pela restrição da atuação dos Tribunais: "Para transformar a Constituição em um sistema prático, esse suposto poder dos tribunais de anular leis passadas pelo Congresso não poder existir em absoluto”57.

Assim é que, em 1802, republicanos temiam que o Ato Judiciário promulgado aquele ano pelo Congresso americano, de maioria republicana, fosse declarado inconstitucional pela Suprema Corte, cujos ministros haviam sido nomeados, em sua maioria, pelo antigo presidente federalista. No entanto, quando um caso questionando a constitucionalidade desse ato chegou à Suprema Corte (Stuart v. Laird), em fevereiro de 1803, Masrshall brilhantemente garantiu que houvesse unanimidade na postura minimalista do Tribunal. A decisão constatou "não haver palavras na Constituição que proíbam ou restrinjam o exercício do poder legislativo" 58 .

Para os menos atentos, Marshall havia sucumbido ao apelo republicano de constrição. Ficou comprovado depois que o movimento de recuo fora calculado com base no cenário político do momento, em que os ânimos republicanos encontravam-se extremamente alterados e a opinião pública enxergava o Judiciário como uma ferramenta nas mãos de um partido político desacreditado. Haveria ainda o tempo de fazer da Suprema Corte aquilo que John Marshall acreditava ser seu papel fundamental: a autoridade final em matéria constitucional. O momento certo ainda não havia chegado, e teria que ser sopesado e cuidadosamente arquitetado ${ }^{59}$.

E eis que a visão política avantajada do presidente da Suprema Corte soube finalmente localizar a oportunidade certa para o salto. Em março de 1801, a comissão para empossar William Marbury como juiz de paz não lhe fora devidamente entregue. Quando chegou então às mãos do Presidente Jefferson, ele ordenou que seu Secretário de Estado não desse cumprimento ao documento. Foi levado, assim, à Suprema Corte, em dezembro de 1801, o pedido de que esta ordenasse a entrega da comissão respectiva a Marbury. Devido ao recesso determinado pelo Congresso, o caso só chegou à apreciação da Suprema Corte em fevereiro de 1803. A Administração tratou o caso como uma tentativa de

\footnotetext{
${ }^{56}$ BURNS, 2009.

${ }^{57}$ Annals of Congress, 7th Congress, 1st session, February 3, 1802, p. 179, tradução minha.

${ }^{58}$ Stuart v. Laird, 5 U.S. (I Cranch) 299 (1803), p. 309, tradução minha.

${ }^{59}$ BURNS, 2009, p. 30.
} 
desestabilização política por parte da oposição, e o réu - o novo Secretário de Estado James Madison - não teve nem representação no Tribunal ${ }^{60}$.

Charles Lee, autor da ação, argumentou que a Corte Suprema, sob o ato judiciário de 1789, tinha autoridade para compelir Madison a exercer seu dever legal de entregar comissões devidamente assinadas e seladas ${ }^{61}$. Caso Marshall deferisse o pedido e ordenasse a entrega da comissão, Jefferson e Madison poderiam facilmente descumprir a ordem, fundando um precedente que desafiaria a atuação da Corte por anos e anos. Mas se, por outro lado, julgasse a favor da Administração, a fraqueza do Poder Judiciário face à autoridade do Executivo restaria exposta, estabelecendo precedente igualmente desfavorável.

Marshall engendrou a seguinte solução em Marbury v. Madison ${ }^{62}$ : decidiu que Marbury tinha sim direito a receber sua comissão e que o Presidente Jefferson não poderia negar-lhe efeito. Mais ainda, afirmou que cabia a Marbury pedir aos Tribunais que obrigassem essa entrega. Até aí a crise parecia incontornável, mas foi então que Marshall mudou o tom e tomou a direção que determinaria um novo rumo para o Direito Constitucional - julgou inconstitucional e, portanto, nulo, o Ato Judiciário de 1789, que havia estabelecido a jurisdição da Suprema Corte em casos como o de Marbury, sem amparo e em conflito com o artigo III da Constituição americana. A Suprema Corte norteamericana não poderia, assim, remediar o mal praticado contra Marbury.

E foi assim, invalidando uma lei que concedia uma pequena medida de autoridade à Suprema Corte, que Marshall garantiu uma em escala muito maior - o poder de declarar inconstitucionais atos emanados do Congresso, inaugurando oficialmente a prática da jurisdição constitucional.

Em termos práticos e para o caso em análise, a vitória foi do partido republicano, uma vez que Marbury nunca receberia a comissão. O conflito direto e aberto foi claramente evitado. O que incomodou Jefferson, contudo, não foi a ampliação dos poderes da Corte, mas a lição de Marshall ao Presidente no sentido de que este deveria ter enviado a comissão a quem de direito. Para Jefferson, tratou-se de uma interferência gratuita, já que a conclusão havia sido pela falta de jurisdição da Suprema Corte. Uma invasão na esfera de atuação do Poder Executivo, onde quem teria a última palavra seria o próprio Presidente ${ }^{63}$.

\footnotetext{
${ }^{60}$ BURNS, 2009.

${ }^{61}$ BURNS, 2009.

${ }^{62}$ Marbury v. Madison, 5 U.S. (1 Cranch) 137 (1803).

63 Jefferson para o Ministro William Johnson, carta de 12 de junho de 1823 in Jefferson, Writings, Merrill D. Peterson, ed. Library of America, 1984.
} 
Fica evidente, pois, que a insistência do Presidente em enxergar a decisão em termos puramente internos o impediu de considerar as amplas implicações que tem o argumento de ser o dever da Suprema Corte dizer o que seria o Direito.

Em sua atuação futura, a Suprema Corte americana iria reafirmar a prática da jurisdição constitucional no caso Cooper v. Aaron, com voto escrito pelo Ministro William Brennan e proferido pelo então Ministro Presidente Earl Warren. Em trecho expressivo, o voto esclarece que Marbury declarou a proposição constitucional básica de que "o judiciário federal é supremo na veiculação do direito constitucional, e esse princípio tem sido desde então respeitado pela suprema corte e pelo país como um traço permanente e indispensável de nosso sistema constitucional” ${ }^{\text {"64 }}$. Com efeito, a jurisdição constitucional e a espécie de controle de constitucionalidade articulada pela Suprema Corte em Cooper são feições características do sistema constitucional americano, e exercem forte influência em diversos sistemas legais mundo afora.

\subsection{O controle de constitucionalidade de leis estaduais na esfera federal}

De volta à Corte de Marshall, pode-se afirmar com folga que liberdade, propriedade e crescimento econômico eram objetivos interligados na mente do ministro presidente, dependendo os três de proteção contra interferência indevida do governo. Essa mentalidade liberal o levou, em Flechter v. Peck, a proferir a primeira grande decisão invalidando uma lei estadual.

Em 1795, legisladores corruptos da Geórgia autorizaram a venda, a quatro grandes empresas, de 35 milhões de acres de uma terra cuja propriedade o Estado alegava possuir. As empresas depois venderam essa terra a especuladores imobiliários. Nas eleições de 1796, a população do Estado, indignada, elegeu uma nova leva de parlamentares, que revogaram a lei na qual fora formalizada a venda em questão. Mas e quanto aos novos donos daquela terra, teria a revogação anulado também seu título?

Marshall decidiu que a lei revogada constituiria verdadeiro contrato de venda de terra, e “quando uma lei é, em sua natureza, um contrato, quando direitos absolutos apresentam-se na forma de contratos, a revogação da lei não pode desagasalhar referidos

${ }^{64}$ Cooper v. Aaron, 358 U.S. 1 (1958), p. 18, tradução minha. 
direitos”65. Mais além, afirmou que a legislatura estadual não estaria imune às leis de propriedade comuns aos cidadãos de todos os Estados Unidos. Transformando uma lei de política pública em matéria privada - propriedade e contrato -, Marshall garantiu status constitucional ao "direito absoluto" de propriedade, além de ter assegurado a jurisdição constitucional da Suprema Corte sobre legislação estadual, declarando inconstitucional a lei estadual de 1796 que revogou a transferência da terra.

Alguns Estados, contudo, continuavam a opor resistência à asserção do poder judiciário federal, como fez a Virgínia - a Suprema Corte do Estado assinalou que a corte suprema da nação não possuía jurisdição revisional sobre julgamentos proferidos por cortes estaduais. Tratava-se de Martin v. Hunter's Lessee, outro complexo caso de direito imobiliário, que foi julgado em 1816 pela Suprema Corte dos EUA e levou o Ministro Story a alertar os cidadãos de Virgínia que julgamentos divergentes proferidos pelas cortes estaduais tornavam essencial a autoridade revisional da Suprema Corte Federal, sob pena de subsistirem diferentes Constituições para cada Estado: “Os desmandos públicos que isso acarretaria seriam verdadeiramente deploráveis”66, concluiu o ministro.

\section{Novos desafios econômicos, o mesmo velho embate institucional}

Compreendido o contexto político subjacente à famosa decisão em Marbury, que fundou a adoção do modelo americano de jurisdição constitucional, compartilha-se da opinião de Marcos Paulo Veríssimo, para quem "seria difícil tirar a razão daqueles que procurassem apontar os critérios que justificaram essa decisão como critérios de natureza eminentemente política, e não de estrita interpretação do direito»67. Marshall, um federalista assumido, garantiu um espaço para ideais federalistas no centro do poder republicano. Não apenas reforçou o poder federal sobre o dos Estados, mas criou também uma doutrina constitucional que poderia fornecer os instrumentos necessários à resistência contra o avanço dos valores republicanos.

\footnotetext{
${ }^{65}$ Flechter v. Peck, 10 U.S. (6 cranch) 87 (1810), p. 134, tradução minha.

${ }^{66}$ Martin v. Hunter's Lessee, 14 U.S. (I Wheaton) 304 (1816), p. 306, tradução minha.

${ }^{67}$ VERÍSSIMO, Marcos Paulo. A Judicialização dos Conflitos de Justiça Distributiva no Brasil: o Processo Judicial no Pós-1988. Tese de Doutorado em Direito Processual - Faculdade de Direito, Universidade de São Paulo, São Paulo, 2006, p. 40.
} 
Conquanto hoje sejam evidentes as falhas lógicas no raciocínio desenvolvido por Marshall em Marbury v. Madison ${ }^{68}$, não é intenção da pesquisa aqui desenvolvida focar seu conteúdo, mas a prática constitucional que ele consolidou, bem como as críticas daí advindas.

E se, em sua origem, o poder de declarar leis do parlamento inconstitucionais esteve interligado a motivações de ordem político-partidárias, assim seria uma vez mais em um dos momentos de grande significado na História americana - o período de colapso econômico conhecido como a “grande depressão”, como se verá abaixo.

\subsection{A era progressista na base da tensão contramajoritária}

O fortalecimento do modelo da revisão judicial tornou-se alvo de críticas de todo tipo, especialmente daquelas que elegeram a dificuldade contramajoritária como o maior empecilho ao seu cabimento. O termo foi alcunhado por Alexander Bickel ${ }^{69}$, constitucionalista americano para quem as instituições políticas representativas, ainda que não perfeitamente majoritárias, constituiriam a característica distintiva de qualquer democracia. As Cortes, simbolizando um poder político não eleito, estariam a rejeitar uma decisão política tomada por agentes representativos da vontade popular ao declarar a inconstitucionalidade de um ato legislativo, o que desvirtuaria toda a base do Estado Democrático de Direito.

Não se deve, contudo, perder de vista o fato de que a crítica de Bickel foi formulada no contexto de reflexão sobre a tentativa de introduzir reformas sociais nos EUA por meio do New Deal (também conhecido como a era progressista), quando Franklin Delano Roosevelt se propôs a tirar o país da "grande depressão", mas encontrou resistência de peso por parte da Suprema Corte americana.

\footnotetext{
${ }^{68}$ Carlos Santiago Nino trata com bastante propriedade das incoerências lógicas da decisão em Marbury (NINO, Carlos Santiago. The Constitution of Deliberative Democracy. New Haven \& London: Yale University Press, 1996). Ele evidencia a falácia presente na conclusão de que é dever lógico do Judiciário, no sistema jurídico que elege a constituição como norma suprema, declarar nulas as normas contrárias à constituição. Nesse sentido, o dever do judiciário de não aplicar uma norma violadora da constituição não pode ser expresso como algo contingentemente necessário, sendo falsa a afirmação de que um sistema que não utilize o controle judicial de constitucionalidade nega a supremacia da constituição. Conceber a constituição como norma suprema, portanto, nada diz sobre qual órgão deve ser chamado a aplica-la. O debate, portanto, tem natureza normativa, não podendo se passar por um pretenso raciocínio lógico.

${ }^{69}$ BICKEL, Alexander M. The Least Dangerous Branch: The Supreme Court at the Bar of Politics, $2^{\mathrm{a}}$ Ed. New Haven and London: Yale University Press, 1986.
} 
Quando Roosevelt prestou o juramento presidencial em 04 de março de 1933, a crise econômica americana parecia não ter fim. Depois da quebra da bolsa em 1929, a nação havia mergulhado em uma catástrofe econômica - milhares de bancos e negócios haviam falido, e quinze milhões de americanos (um terço da força de trabalho) estavam desempregados. O antigo Presidente Hoover, criticado por não ter feito nada para enfrentar a crise, foi derrotado nas eleições de 1932, varrendo os republicanos para fora do poder e colocando o Congresso em mãos democratas.

O novo presidente começou por lançar o maior programa de alívio à dívida na História americana, estendendo regulação federal sobre bancos, mercado de ações e transporte, e determinando a reestruturação das dívidas hipotecárias para impedir que cidadãos perdessem seus lares. Quanto à agricultura - cujos preços haviam despencado e não chegavam nem ao custo total de produção -, foi promulgado pelo congresso o Ato para recuperação da indústria nacional (National Industrial Recovery Act - NIRA), em junho de 1933. A medida buscava pôr fim ao antigo conflito entre capital e trabalho, permitindo o desenvolvimento de regras justas de concorrência, supervisionada pelo presidente, bem como conferir autoridade ao governo para regular as relações trabalhistas ${ }^{70}$.

Essa e algumas outras medidas sofreram inexpressiva oposição republicana no Parlamento, mas quando chegaram à Suprema Corte americana, foram massacradas. O então Ministro Presidente da corte, Charles Evans Hughes, dizia-se ultrajado pelas medidas do New Deal. Em sua companhia estavam os quatro ministros de extrema direita da corte, também conhecidos como "os quatro cavaleiros” (the Four Horsemen), Van Devanter, McReynolds, Sutherland e Butler. A minoria liberal era composta por Brandeis, Stone e Benjamin Cardozo. O nono ministro, Owen Roberts, um republicano da Pennsylvania fortemente conectado à indústria ferroviária, costumava aliar-se aos quatro cavaleiros na maioria dos julgamentos ${ }^{71}$.

Para a ala conservadora da Corte, o New Deal era um ataque brutal aos valores que defendiam. Era absurda a noção de que a crise econômica justificasse "violações da santidade de contratos públicos e privados”, como veio a escrever o Ministro Sutherland em 1934. O sentido da Constituição, segundo ele, permanecia imutável, sendo que "o

\footnotetext{
${ }^{70}$ PATTERSON, James T. Congressional Conservatism and The New Deal: The Growth of the Conservative Coalition in Congress, 1933-1939. University of Kentucky Press, 1967.

${ }^{71}$ BURNS, 2009, pp. 140-141.
} 
objetivo da construção seria descobrir seu significado, assegurar e realizar a intenção de seus idealizadores (framers) e do povo que o adotou"72.

Em 25 de maio de 1935, dia conhecido como a “segunda-feira negra” (Black Monday), três grandes golpes foram desferidos pela Suprema Corte contra medidas engendradas pelo presidente. Uma lei destinada a reduzir despejos e falências rurais foi anulada por violar direitos de credores, a tentativa de Roosevelt de retirar um republicano que vetava medidas do New Deal da Câmara Federal do Comércio foi invalidada, e, por fim, em Schechter Poultry Corp. v. U.S., a Corte anulou o estandarte da política do New Deal, o NIRA.

E assim continuou a Corte no ataque contra o New Deal. Negando que a crise na agricultura fosse uma questão de bem-estar geral, anulou provimentos afirmando que o problema de agricultores eram questões locais, para além do alcance do poder federal. A legislação que regulava a sindicalização de trabalhadores nas minas de carvão foi igualmente invalidada, ao argumento de que o setor representava mais uma atividade local, assim como a agropecuária e a manufatura: “a relação entre empregador e empregado é de natureza local”73, imune, portanto, à interferência federal, afirmou o Ministro Sutherland. Condições extraordinárias, na opinião do Ministro Hughes, "não criam ou expandem o poder constitucional”74.

Nesse ritmo, mais de doze leis federais e estaduais foram invalidadas em dezoito meses. Em junho de 1936, o Presidente Roosevelt declarou à imprensa que os EUA eram "uma terra de ninguém, onde nenhum governo - estadual ou federal - pode funcionar"75.

James McGregor Burns, em obra voltada a comprovar a parcialidade política presente na Suprema Corte americana desde seus primórdios ${ }^{76}$, relata terem sido duas as estratégias consideradas pelo presidente para reverter tal quadro: a primeira era uma reforma que desse ao Congresso autoridade constitucional expressa para regular mercado e relações trabalhistas, e a outra era também uma reforma, mas uma que limitasse os poderes de revisão judicial da Suprema Corte. A segunda alternativa ganhava mais e mais adeptos entre os parlamentares. Falava-se em uma emenda constitucional que desse ao povo do presente o direito de lidar com questões vitais do presente como bem entendessem.

\footnotetext{
${ }^{72}$ Home Building \& Loan Association v. Blaisdell, 290 U.S. 398 (1934), p. 448, tradução minha.

${ }^{73}$ Carter v. Carter Coal Co., 298 U.S. 238 (1936), p. 291, tradução minha.

74 Schechter Poultry Corp. v. U.S., 295 U.S. 495 (1935), p. 542, tradução minha.

${ }^{75}$ Entrevista à imprensa, 02 de junho de 1936, in Roosevelt, Public Papers, vol. 5, p. 192, tradução minha.

${ }^{76}$ BURNS, 2009.
} 
No entanto, o plano exigia a aprovação de uma emenda constitucional, com todas as dificuldades procedimentais correspondentes e sujeição ao risco de, ao final, ter seu sentido desconfigurado pela própria Suprema Corte. Poderia ser tarde demais para salvar o New Deal. Roosevelt então colocou a ideia de lado e concentrou-se na possibilidade de mudar a composição política da Corte com ministros ideologicamente favoráveis ao novo rumo política que imaginava para o país, adotando projeto que ficou conhecido como court-packing plan ${ }^{77}$.

Ocorre que até o mais velho dos ministros que compunham a Suprema Corte americana de então poderia muito bem sobreviver inclusive ao segundo termo de Roosevelt, segundo cálculos estáticos encomendados à época. A solução, assim, estaria em adicionar mais cadeiras ao Tribunal.

Em sua campanha para a reeleição em 1936, contrário à expectativa geral, Roosevelt não incluiu a reforma da Suprema Corte como uma de suas propostas. Quando, já eleito, finalmente fez sua intenção pública em mensagem ao Legislativo e o Congresso veio abaixo em críticas e desconfiança ao plano secretamente formulado pelo presidente com alguns aliados. Roosevelt justificou estar simplesmente preocupado em aprimorar a eficiência do Tribunal, mas poucos no Parlamento comprariam esse discurso.

O presidente, entretanto, contava com expressivo apoio popular, e mesmo que a reforma pretendida opusesse dificuldades políticas imensuráveis àquela altura, os ministros da Suprema Corte, argumenta Burns, sentiram o perigo se avolumando e se aproximando ${ }^{78}$.

Uma semana depois de lida a mensagem do presidente informando aos senadores de seu plano para reformar a Suprema Corte, foram anunciadas quatro decisões assinalando mudança extraordinária de rumo. No caso mais importante, West Coast Hotel v. Parrish, por uma maioria de 5 votos a 4, a Suprema Corte declarou válida uma lei de Washington prevendo salário mínimo para mulheres e menores - disposição idêntica àquela de uma lei nova-iorquina invalidada pela corte por 5 x 4 no ano anterior (Morehead v. New York ex rel. Tipaldo). O Ministro Owen Roberts foi quem mudou seu voto, no que passou a ser conhecido como "a mudança no tempo que salvou nove” (the switch in time that saved nine).

${ }^{77}$ KYVIG, David E. The Road Not Taken: FDR, the Supreme Court, and Constitutional Amendment. Political Science Quarterly, v. 104, n. 3, 1989.

${ }^{78}$ BURNS, 2009, p. 149. 
Burns, ao tentar provar em sua obra que a mudança de posição foi calculada para proteger a Corte, afirma que, apesar do Ministro Presidente Hughes ter negado a existência de pressão sobre o Ministro Roberts para que mudasse de entendimento, vinte anos depois, o próprio Roberts reconheceu haver estado "totalmente consciente da tremenda ameaça"79 imposta por Roosevelt ao Tribunal.

É certo, portanto, que esse período da História política americana foi dominado por forte tensão entre a democracia - contemplada nas medidas legislativas de amplo apoio popular fomentadas por Roosevelt para regular o mercado e estabelecer direitos sociais - e o constitucionalismo - retratado na rejeição sucessiva de tais medidas pela Suprema Corte, no papel de guardiã da Constituição.

Não é de se admirar, assim, que as críticas centradas no argumento da natureza contramajoritária da revisão judicial de provimentos parlamentares tenham ganhado força justamente quando a doutrina parou para refletir sobre os acontecimentos da "era progressista”, como argumenta Whittington ${ }^{80}$.

Emblemático desse sentimento crescente é o discurso de Roosevelt em setembro de 1937, por ocasião do aniversário de 150 anos da assinatura da Constituição na Convenção de Filadélfia:

Contrariamente à crença de alguns americanos, a Constituição não diz nada sobre o poder da Suprema Corte de declarar a legislação inconstitucional; tampouco menciona o número de juízes que devem compor a Corte. Repetidas vezes a Convenção rejeitou propostas que dessem aos ministros da Corte poder de veto sobre a legislação. Claramente, a maioria dos delegados acreditava que a relação entre a Corte e o Congresso e o Executivo, assim como outros temas tratados em termos genéricos, se ajustaria por meio de evolução e mudança durante os anos. Mas por cento e cinquenta anos, tivemos um embate sem fim entre aqueles que queriam preservar esse conceito original amplo de constituição como instrumento do homem comum para governar e aqueles que queriam transformar a constituição em contrato de advogado ${ }^{81}$.

\footnotetext{
${ }^{79}$ CUSHMAN, Barry. The Secret Lives of the Four Horsemen. Virginia Law Review, vol. 83, n. 3, 1997, p. 44.

${ }^{80}$ WHITTINGTON, 2002-2003.

81 “Address on Constitution Day”, 17 de setembro de 1937, in Roosevelt, Public Papers, vol. 6, pp. 362-364, minha tradução.
} 


\section{Modelos de comportamento judicial}

\subsection{Considerações político-sociais sobre o Judicial Review americano}

Fica evidente, pois, que as origens do fortalecimento do Poder Judiciário americano e, portanto, a própria evolução do instituto do judicial review estão intrinsicamente ligadas, em todo seu caminho de solidificação na História constitucional americana, a momentos de resistência de elites dirigentes - seja no Executivo ou no Legislativo, seja no Judiciário contra alterações no status quo, como se procurou demonstrar nas linhas acima.

E muito embora a influência da ideologia política e a tentativa de conservação do próprio poder pela Corte sejam traços recorrentes na evolução da jurisdição constitucional americana - ora determinando uma atuação progressista da Corte, ora garantindo a manutenção de paradigmas conservadores - Frederick Schauer ${ }^{82}$ vem ressaltar a importância de se notar que, diferentemente de muitos, talvez da maioria, dos debates constitucionais, o debate sobre a jurisdição constitucional em si não carrega uma ambivalência política óbvia e recortada.

Ainda que decisões mais recentes da Era Rehnquist (Corte eminentemente conservadora) tenham defendido entusiasticamente a ideia da supremacia judicial ${ }^{83}$, o debate remonta a pronunciamentos similares sobre a supremacia judicial em Cooper $v$. Aaron, um ícone da Corte de Warren (Corte eminentemente liberal). Mais recentemente, segundo Schauer, conquanto o Professor Kramer e outros que atacam, ou ao menos questionam, a supremacia judicial sejam considerados exemplos de membros da centroesquerda no debate político americano contemporâneo, o ataque acadêmico atual teria sido iniciado por conservadores como Michael Paulsen ${ }^{84}$ e Gary Lawson ${ }^{85}$.

\footnotetext{
82 SCHAUER, 2004.

${ }^{83}$ Schauer enumera, a título de exemplo, os seguintes julgados da Suprema Corte americana: Kimel v. Fla. Bd. of Regents, 528 U.S. 62 (2000); United States v. Morrison, 529 U.S. 598 (2000); Dickerson v. United States, 530 U.S. 428 (2000); City of Boerne v. Flores, 521 U.S. 507 (1997).

${ }^{84}$ PAULSEN, Michael Stokes. The Most Dangerous Branch: Executive Power to Say What the Law is. 83 GEO. L.J. 217, 1994.

${ }^{85}$ LAWSON, Gary \& MOORE, Christopher D. The Executive Power of Constitutional Interpretation. 81 IOWA L. Rev. 1276, 1996.
} 
Ademais, a posição apresentada por Kramer e Paulsen teria sido abraçada em 1986 por Edwin Meese III ${ }^{86}$, Advogado-Geral de Ronald Reagan, assim como questionamentos à supremacia judicial constituíam o foco do programa conservador no início da Administração de George H. W. Bush ${ }^{87}$. Por outro lado, no passado, oposições à autoridade judicial na interpretação constitucional foram igual e solidamente apresentadas pelos Presidentes Abraham Lincoln ${ }^{88}$ e Franklin Roosevelt, este último nos termos já retratados acima.

Frederick Schauer reconhece que a generalização acima anunciada ignora diversas variantes e detalhes importantes presentes em cada um dos casos, mas considera a história bipartida de ambos os lados da questão suficiente para demonstrar que o debate sobre a supremacia judicial não é uma simples dicotomia entre esquerda versus direita, liberal versus conservador ou democrata versus republicano. Não se pode, portanto, ignorar que defensores e críticos contemporâneos da jurisdição constitucional passam por todo o spectrum ideológico. Nas palavras do autor:

\begin{abstract}
Por mais tentador que seja para alguns enxergar a maré da supremacia judicial como basicamente uma agenda da Corte de Rehnquist ou uma agenda conservadora, os fatos desmentem tal caracterização. A própria existência de alianças políticas incomuns, por mais que se tente ignorá-las, é simplesmente prova da importância consistente e fundamental da questão ${ }^{89}$.
\end{abstract}

\title{
6.2 Superando a dicotomia legalista $x$ atitudinal - o modelo "neoinstitucional”
}

Na doutrina, a tentativa de mapear a atividade jurisdicional por meio da investigação das decisões de juízes deu origem a teorias de modelos de comportamento judicial, dentre as quais figura o modelo “legalista”, que, em sua formulação clássica, considerava as regras jurídicas como fontes de sentido claro em casos rotineiros, encontrando-se a função judicial estritamente vinculada ao Direito (doutrina, normas, precedentes etc.). Esse modelo foi, contudo, fortemente criticado pelo realismo jurídico, que veio defender que o Direito não constitui, na prática, um verdadeiro limite externo à atividade judicial. O modelo legalista, então, aprimorou-se e passou a considerar o Direito

\footnotetext{
${ }^{86}$ MEESE, Edwin. The Law of the Constitution. 61 TUL. L. REV. 979, 1987.

${ }^{87}$ GRONER, Jonathan. Election Fight Lights Spark Under the Right. Legal Times, 04 de dezembro de 2000.

${ }^{88}$ LINCOLN, Abraham. First Inaugural Address, in 4 The Collected Works of Abraham Lincoln 262, 268 (Roy P. Basler ed.), 1953.

${ }^{89}$ SCHAUER, 2004, p. 1051, tradução minha.
} 
como um limite interno à função judicial, porquanto juízes, munidos de treinamento jurídico e imbuídos do ethos de aplicação das normas jurídicas pertinentes ao caso, determinariam a influência do Direito em medida muito maior do que aquela apontada pelos críticos ${ }^{90}$.

Todavia, depois de superada a Era Lochner e de ter sido afirmada a constitucionalidade das medidas do New Deal de Roosevelt - nos termos já descritos acima -, a existência de visões constitucionais diametralmente opostas estabelecidas na mesma década pela Suprema Corte americana enfraqueceram sobremaneira a crença na objetividade do Direito e em sua capacidade de impor parâmetros efetivos às cortes ${ }^{91}$.

Origina-se daí a concepção do modelo “atitudinal”, como alternativa na análise do comportamento judicial. De acordo com esse modelo, a principal influência dos juízes ao decidirem questões morais controvertidas seria sua ideologia, e não textos normativos, precedentes ou doutrina jurídica. Não havendo metodologia segura para aferir se uma decisão de fato corresponde às íntimas convicções do juiz, dizer que o Direito seria um constrangimento interno à função judicial seria uma falácia ${ }^{92}$.

Após anos comparando votos dos ministros da Suprema Corte e indícios que revelassem sua orientação ideológica liberal ou conservadora, Jeffrey Segal e Harold Spaeth, expoentes do modelo atitudinal, chegaram à dura conclusão de Rehnquist votava da forma como votava porque era extremamente conservador, e Marshall votava como votava porque era extremamente liberal $^{93}$. A ciência política adotou extensivamente o modelo atitudinal para descrever realisticamente o posicionamento de juízes.

Diante do embate travado entre os dois modelos a partir de então, Friedman ${ }^{94}$ é um dos que vem alertar para o equívoco de se eleger um deles como o correto - ambos possuem defeitos e virtudes. O modelo atitudinal peca por desconsiderar em absoluto a vinculação do juiz ao Direito, mas acerta ao supor que essa relação não é tão forte como propugnam os legalistas. O modelo legalista, por sua vez, acerta ao defender que o ethos profissional dos juízes direciona sua atuação para a aplicação imparcial do Direito, mas erra quando desconsidera por completo a influência de fatores extrajurídicos, como a ideologia, principalmente quando entram em jogo questões morais controvertidas.

${ }^{90}$ BARNES, Jeb. Overruled? Legislative overrides, pluralism and contemporary Court-Congress relations. Stanford: Stanford University Press, 2004.

${ }_{91}^{91}$ FRIEDMAN, Barry. The Politics of Judicial review. Texas Law Review, v. 84, n. 2, 2005.

${ }^{92}$ BARNES, 2004.

${ }^{93}$ SPAETH, Harold J. \& SEGAL, Jeffrey A. The Supreme Court and the attitudinal model. Cambridge: Cambridge University Press, 1993.

${ }^{94}$ FRIEDMAN, 2005. 
Para comprovar o que se afirma acima, nada mais oportuno, segundo Rodrigo Brandão, que a análise da Jurisprudência atual do Supremo Tribunal Federal brasileiro:

\begin{abstract}
A observação da jurisprudência contemporânea do STF nos dá sinais contraditórios: por um lado, a pequena aderência ao texto e aos seus precedentes parece vincular o STF ao modelo atitudinal; por outro, a circunstância de o STF ter assistido a transições de coalizões partidárias no controle do governo federal sem alterar, significativamente, a forma de sua atuação (agindo de forma mais ou menos ativista), depõe a favor de uma postura de independência e de vinculação ao Direito (e não a preferências político-ideológicas do partido dominante). Todavia, não se trata de 'incoerência' peculiar ao constitucionalismo brasileiro, antes tal cenário decorre das insuficiências atreladas ao uso exclusivo de qualquer um dos modelos anteriormente descritos ${ }^{95}$.
\end{abstract}

Assim é que, a partir de 1980, começa a ser desenhada uma nova proposta de superação dessa dicotomia entre os modelos de comportamento - chama-se "neoinstitucionalismo", e busca identificar a vontade de determinada instituição como a combinação da perspectiva coletiva de seus agentes com sua cultura institucional. O comportamento individual de juízes e legisladores ainda é objeto de análise, como nos modelos legalista e atitudinal, mas se confere foco especial à interação entre os Poderes. A dinâmica de interação entre instituições ganha destaque na imposição de limites à atuação de agentes públicos ${ }^{96}$.

Louis Fisher ${ }^{97}$, em 1988, identificou alguns mecanismos institucionais, de titularidade do poder legislativo, limitadores da Suprema Corte em sua tarefa de interpretar a Constituição - sendo sua a última palavra ou não. Entre eles encontram-se a possibilidade de alteração do número de seus membros, a manipulação de sua competência e o impeachment de ministros para fins não disciplinares. Nesse cenário, há forte tendência de que os estudiosos empíricos das relações entre Parlamento e Corte tratem indistintamente ataques institucionais à Suprema Corte como simples mecanismos de reversão de decisões judiciais. É o que faz Whittington ${ }^{98}$, quando estabelece que tais

\footnotetext{
${ }^{95}$ BRANDÃO, 2012, p.226.

${ }^{96}$ MILLER, Mark C. The view of the courts from the hill: a neo institutional perspective. In: MILLER, Mark C. \& BARNES, Jeb (ed.). Making policy, making law: an interbranch perspective. Washington, DC: Georgetown University Press, 2004.

${ }^{97}$ FISHER, Louis. Constitutional dialogues - interpretation as a political process. Princeton University Press, 1988.

${ }^{98}$ WHITTINGOTN, Keith. Legislative sanctions and the strategic environment of judicial review. I-Con: The International Journal of Constitutional Law, v. 1, July 2003.
} 
medidas são utilizadas estrategicamente pelo Legislativo para fazer prevalecer suas preferências sobre a Suprema Corte.

Rodrigo Brandão, no entanto, defende que ataques institucionais à Corte são prejudiciais à implantação do Estado de Direito, enfraquecendo a independência judicial e intimidando os juízes caso necessitem, legitimamente, limitar o poder estatal ${ }^{99}$. Nesse sentido, propostas como a de Larry Kramer, defendendo a reorientação do curso da jurisprudência de uma Corte Suprema por meio de expedientes como "o impeachment de juízes, cortes no orçamento do Judiciário, descumprimento das decisões da Suprema Corte, encolhimento de suas competências, ou aumento do número de seus membros»"100, deveriam ser vetadas.

No capítulo seguinte, a atenção da pesquisa volta-se para os antagonistas da prática da jurisdição constitucional e os argumentos centrais lançados na tentativa de convencer acerca da necessidade de que o Poder Legislativo detenha a última palavra na definição e realização de direitos. Em um segundo momento, a análise volta-se para o outro lado do embate, agora fazendo do Poder Legislativo o alvo do escrutínio e o objeto das críticas, apresentadas pela doutrina com o propósito de evidenciar que às Cortes deve ser atribuído o poder da última palavra na interpretação constitucional.

99 BRANDÃO, 2012. Assim ilustra o seu argumento: "O vínculo entre independência judicial e Estado de Direito é singularmente ilustrado por uma história apócrifa sobre Frederico, o Grande: incomodado com o barulho incessante de um moinho de vento localizado em um milharal vizinho à sua residência de verão (Palácio de Sanssouci, em Potsdam), o rei da antiga Prússia formulou uma proposta de compra de terreno, e o seu proprietário prontamente a recusou. Irresignado, Frederico teria lhe dito: Você não sabe que posso usar os meus poderes para tomar o seu milharal sem lhe pagar nada? Ao que o proprietário retrucou: Com todo respeito, Vossa Majestade poderia fazê-lo, se não houvesse juízes em Berlim. Com efeito, a noção de que Cortes devem ter a sua independência garantida para controlar abusos dos governos, especialmente quando resvalarem sobre os direitos humanos, ocupa papel central no pensamento constitucional ocidental contemporâneo"(BRANDÃO, 2012, p. 231).

${ }^{100}$ BRANDÃO, 2012, p. 231. 


\section{- CAPÍTULO II - \\ CORTE X PARLAMENTO: \\ A PERSPECTIVA DA “ÚLTIMA PALAVRA"}

\section{Visões críticas sobre o Poder Judiciário e a Jurisdição Constitucional}

\subsection{A supremacia do Legislativo na voz de Jeremy Waldron}

Jeremy Waldron, constitucionalista contemporâneo e professor da NYU, propugna tese contra a revisão judicial já bastante conhecida, que se funda primordialmente no direito à participação e na regra da maioria. Nesse capítulo dedicado aos argumentos contrários à supremacia judicial e favoráveis à supremacia legislativa, sua presença é intensa, muito pela repercussão de sua teoria no mundo acadêmico, representando uma guinada animada no debate constitucional ${ }^{101}$.

Com a visão de Waldron em foco, encontra-se no cerne de sua teoria o argumento de que a jurisdição constitucional ignora o desacordo moral típico de uma sociedade plural - característica típica da política atual. Delegar a juízes decisões sobre questões moralmente controversas significa desrespeito ao traço mais valioso da democracia: a inexistência de hierarquia entre cidadãos, que devem ter garantida a possibilidade de decidir seus dilemas coletivos sob condições estritamente iguais. Caso não seja possível

101 Whittington atribui a Waldron o mérito de haver alterado o enfoque do debate em torno do constitucionalismo, cujas teorias centrais vinham tomando a revisão judicial como algo dado, indispensável mesmo ao funcionamento da democracia constitucional. (Cf. WHITTINGTON, Keith E. An "indispensable Feature”? Constitutionalism and judicial review. NYU Journal of Legislation and Public Policy, 2002-2003). 
obter acordo sobre determinada questão, então o objeto do acordo deverá transformar-se na própria escolha de um procedimento específico para que se decida a questão. O direito à participação consolida-se, assim, como o maior de todos os direitos, permitindo que todos satisfaçam sua condição de indivíduos autônomos por meio de uma votação pública ${ }^{102}$.

O constitucionalista voltou recentemente ao tema, com nova obra em que pretende apresentar seu “argumento essencial” contra a revisão judicial ${ }^{103}$. "Essencial” por não estar vinculado a Constituições nacionais ou decisões específicas, em esforço empreendido na busca de pretensão universal.

Waldron, na obra mencionada, passa a admitir que, em situações excepcionais, a revisão judicial pode ser desejável, mas permanece convicto de sua raiz antidemocrática. Ele define uma situação típica, que deve conjugar quatro elementos: (a) instituições democráticas em bom funcionamento, (b) instituições judiciais não representativas em bom funcionamento, (c) um compromisso genuíno da maioria da sociedade com a ideia de direitos e (d) um persistente desacordo de boa-fé sobre direitos.

Se um desses quatro componentes não estiver presente, e a situação constituir um estado endêmico, tem-se consolidado então um quadro atípico e patológico, o que não significa, entretanto, que a revisão judicial seja uma alternativa automática, pois ainda há o ônus de justificá-la no contexto específico. Os custos de se recorrer a essa prática elitista só faria sentido em casos como o de Parlamentos disfuncionais, culturas políticas corruptas ou legados de racismo, dentre outros. A revisão judicial não pode, contudo, ser considerada um "epítome do respeito a direitos” ou um elemento sempre desejável da democracia. Seria apenas uma solução não ideal para circunstâncias extraordinárias.

Para Keith E. Whittington ${ }^{104}$, Bickel foi quem primeiro fixou os rígidos limites do debate acadêmico tradicional empreendido pela teoria constitucional americana ao assumir a jurisdição constitucional como algo dado, apenas questionando como ela deve ser exercida. O diferencial em Waldron, ressalta Whittington, está em desafiar a noção da jurisdição constitucional como traço indispensável ao constitucionalismo em geral, em seu esforço para provar que um sistema constitucional - qualquer que ele seja, ainda que diferente do americano -, não está intrinsicamente vinculado à prática da jurisdição constitucional.

\footnotetext{
${ }^{102}$ WALDRON, Jeremy. Law and Disagreement. Oxford: Oxford University Press, 1999.

${ }^{103}$ WALDRON, Jeremy. The core of the case against judicial review. Yale Law Journal, v. 115, 2006.

${ }^{104}$ WHITTINGTON, 2002-2003.
} 
Isso porque, na argumentação de Waldron, democracia e liberalismo - ou democracia e constitucionalismo - não representam ideais contraditórios ou necessariamente conflitantes. Pelo contrário, democracia e liberalismo teriam sido construídos sobre a mesma fundação, sendo inclusive possível fundamentar o constitucionalismo em uma ampla noção de democracia ${ }^{105}$. Essa visão, para Whittington, em nada se assemelha à forma como o constitucionalismo vem sendo discutido na teoria constitucional, que ainda gravita em torno das ideias atinentes à dificuldade contramajoritária de Bickel.

A seguinte passagem de Whittington bem reflete o novo sentido que se busca extrair do constitucionalismo:

\begin{abstract}
A teoria constitucional dessa natureza compartilha muitos dos mesmos defeitos da filosofia política a que Waldron chama nossa atenção: uma confiança infundada de que sabemos as respostas corretas para as questões políticas difíceis e que simplesmente queremos que alguém imponha essas respostas ao mundo em nosso lugar. Mas também podemos pensar sobre a teoria constitucional de uma forma mais ampla, preocupados com questões de design institucional e renovação constitucional que podem criar um mundo político no qual existam tanto desacordo fundamental quanto o respeito por direitos, e como fazê-los consistentes um com o outro ${ }^{106}$.
\end{abstract}

\title{
1.2 Repensando Waldron na voz de Whittington
}

Inspirado pelas ideias renovadoras de Waldron, Whittington, contudo, reconhece não ser ele próprio favorável ao total abandono da jurisdição constitucional, mas acredita que os argumentos centrais da tese do autor de Law and Disagreement ainda guardam espaço para um instituto semelhante à revisão constitucional ${ }^{107}$. Talvez não aquela praticada até hoje nos EUA durante quase todo o século vinte, mas alguma coisa próxima à revisão constitucional que ainda merece ser preservada.

Whittington reconhece que a sugestão de Waldron de como uma democracia deve funcionar e sua premissa de como indivíduos devem ser considerados portadores de direitos são noções consistentes com algum tipo de instituição que ofereça uma segunda (e sóbria) consideração sobre as decisões que são tomadas em determinados arranjos institucionais. Em alguns casos, Waldron descreve traços institucionais de legislaturas, e de

\footnotetext{
${ }^{105}$ WHITTINGTON, 2002-2003.

${ }^{106}$ WHITTINGTON, 2002-2003, p. 23, tradução minha.

${ }^{107}$ WHITTINGTON, 2002-2003.
} 
como esses traços seriam decorrência de premissas filosóficas sobre as necessidades a que serviriam. Sua teoria, contudo, opera em nível de abstração muito elevado, com pouca atenção relegada a detalhes sobre o design institucional das legislaturas.

Não há, a título de exemplo, preocupação sobre características do governo representativo, sobre como legislaturas melhor representariam seus constituintes, ou sobre aspectos problemáticos da relação entre os eleitores e seus representantes. Waldron, por vezes, pula do governo representativo para a democracia direta e referendos, sem entrar a fundo nos problemas que distorcem a vontade popular no trajeto até a realização de direitos. Por essas razões de ordem prática, Whittington admite que pode fazer sentido a existência de uma instituição especializada que também possa ao menos oferecer uma análise detida das decisões produzidas por corpos democráticos - mesmo que seja possível ao corpo democrático, depois dessa revisão, apreciar uma vez mais o que restou decidido.

A segunda sugestão que oferece levanta a possibilidade de que uma instituição com poderes de revisão judicial insista em alguns requisitos procedimentais sobre o resultado do que maiorias legislativas democráticas produziram. O Judiciário, por exemplo, poderia impor parâmetros factuais rígidos antes que o Legislativo passasse certas medidas. A Corte de Rehnquist sugeriu que isso era o que estava tentando realizar em algumas decisões sobre o federalismo, insistindo que o Congresso criasse registros factuais para justificar a ampliação da autoridade federal sobre governos estaduais. Independentemente da adequação da atuação da Corte de Rehnquist nesses casos particulares, faz sentido que Cortes insistam que leis sejam consideradas com algum indício de prova, representando uma visão clara do que maiorias legislativas de fato acreditam $^{108}$.

O terceiro ponto levantado por Whittington cuida da ausência de menção nas obras de Waldron a uma questão muito comum no contexto americano, que é o federalismo. Grande parte da revisão constitucional realizada pela Suprema Corte americana não foi exercitada em face do Congresso e maiorias democráticas nacionais, mas contra legislaturas estatais representando maiorias políticas locais ${ }^{109}$.

\footnotetext{
${ }^{108}$ WHITTINGTON, 2002-2003.

109 Confira-se: “As mais controversas assertivas do poder de revisão judicial pela Suprema Corte foram realizadas, por exemplo, para alinhar o Sul e seu conjunto de políticas raciais nas décadas de 50 e 60 com as visões liberais e progressistas de uma maioria nacional mais ampla; alinhar o Estado de Connecticut e sua legislação sobre o aborto com o que a Igreja protestante e a Igreja católica pós-Vaticano II acreditavam na década de 60, e de acordo com o que os outros Estados já haviam se adequado; e para alinhar departamentos de polícia locais, talvez especialmente no Sul, com procedimentos policiais nacionais, e com o que a Administração nacional julgava ser consistente com a legislação policial mais moderna” (WHITTINGTON, 2002-2003, pp. 27-28, tradução minha).
} 
Vale notar a relevância que ainda carrega a questão do federalismo nos dias atuais, considerando-se que a integração da Europa e a rede de acordos supranacionais na região foram responsáveis por introduzir a semente da revisão judicial na terra em que teve origem a soberania parlamentar - a Inglaterra ${ }^{110}$.

A quarta possível função para a revisão judicial, compatível com as preocupações de Waldron, consistiria no reforço de limites institucionais. John Marshall argumentou em Marbury que a força de uma Constituição estava em não deixar que o Congresso julgasse os limites de seu próprio poder. A autoridade do Congresso é limitada em três pontos: pelos direitos reservados ao povo, pelos poderes atribuídos aos Estados da Federação, e pelos poderes alocados em outros departamentos do governo nacional. Ao negligenciar o ambiente institucional em que as legislaturas atuam, Waldron teria subestimado os problemas advindos de deixar o controle do Poder Legislativo aos cuidados de seus próprios agentes.

Finalmente, há a questão real das minorias distintas, em que não sobressai com clareza quais devem ser os direitos e bens políticos imunes à revisão judicial, de acordo com a teoria de Waldron. Existe uma variedade de minorias que podem ser distinguidas, identificadas e separadas dentro do processo legislativo e do processo democrático - para essas minorias, Whittington acredita que faça sentido tentar erigir limites institucionais voltados a sua proteção.

A ausência do tema "minorias insulares" na teoria de Waldron é chocante para Whittington, na perspectiva da teoria constitucional americana. Sua análise da revisão judicial parte de uma perspectiva filosófica, e seus parâmetros referenciais são os países que compõem a Grã-Bretanha, e não os EUA. Como a questão das minorias tem sido uma das justificativas centrais para o exercício ativo da jurisdição constitucional americana desde cedo, desafiar sua prática nos EUA sem enfrentar diretamente esse ponto traz sérias dificuldades para qualquer teoria. Nesse sentido:

Waldron geralmente fala de uma única comunidade política e a necessidade de que essa comunidade faça decisões sobre seu próprio futuro. O problema, por certo, é que dentro de uma sociedade como os EUA, existe na verdade uma conglomeração de muitas diferentes comunidades políticas, e às vezes essas comunidades políticas individuais são reconhecidas como distintas e fora da maioria. É bem possível que a maioria tome decisões que afetam essas comunidades primariamente, mas que não afetam a própria maioria ${ }^{111}$.

\footnotetext{
${ }^{110}$ WHITTINGTON, 2002-2003, p. 28.

${ }^{111}$ WHITTINGTON, 2002-2003, p. 31, tradução minha.
} 
A problemática das minorias, no trabalho de Waldron, aparece apenas de forma oblíqua: ele alerta que as mesmas premissas liberais que fundam a importância dos direitos também implicam que seja levada a sério a razoabilidade dos atores políticos envolvidos na arena da democracia, inclusive das maiorias políticas. A teoria liberal-democrática requer, assim, que se respeitem os opositores políticos como seres capazes de atuar com base no melhor julgamento moral, e não apenas considerando seu interesse próprio.

Ainda assim, rebate Whittington, há razões para acreditar que interesses próprios acabam por influenciar a política democrática recorrentemente, e um designer constitucional ponderado deve considerar esse fato e prever salvaguardas no sistema constitucional. Mesmo que se acredite que indivíduos geralmente são capazes de pensar além de seu interesse imediato e atuar com plena consciência moral, e que muitas das disputas envolvendo direitos são ao menos parcialmente relacionadas a reais desacordos morais, segue sendo prudente a possibilidade de limitar, eventualmente, as consequências de decisões majoritárias. Pode ser que, vez ou outra, a perspectiva moral da maioria não leve em conta preocupações da minoria. Juízes, nesse cenário, poderiam estar em melhor posição para reconhecer tais efeitos, não porque sejam intrinsicamente mais inteligentes ou mais aptos ao exercício de poder político, comparados aos legisladores ou cidadãos comuns, mas porque seu posicionamento institucional lhes confere acesso a diferentes informações, perspectivas e incentivos ${ }^{112}$.

Pode haver certas disputas, contudo, as quais o Judiciário não deveria tentar solucionar - mesmo que envolvam direitos -, precisamente porque teria pouco a acrescentar ao debate já existente, além da própria asserção de sua autoridade institucional de tomar decisões. Em muitos casos não há dúvidas de que direitos e valores constitucionais estejam em jogo, mas ainda assim pendem questionamentos quanto à forma como o conflito deve ser decidido. Para alguém que, como Whittington, segue defendendo algum tipo de revisão judicial, o argumento de Waldron funciona para aconselhar humildade judicial e disposição a abster-se do exercício do poder quando isso se mostrar

\footnotetext{
${ }^{112}$ Whittington suscita a possibilidade de que Waldron tenha pensado apenas em certos direitos específicos ao formular sua teoria: "One difficulty with Waldron's book is that his discussion of rights is pitched at a high level of abstraction. Not only does he avoid specific constitutional cases, but he also avoids discussing particular substantive rights that are of concern in actual politics. It seems likely that Waldron's argument is shaped in part by having certain kinds of rights disputes in mind, ones in which the moral disagreement about rights seems real and the rights at stake seem generally shared. It seems possible that Waldron would approach the question differently if his paradigmatic cases involved factors such as racial segregation or the torture of prisoners" (WHITTINGTON, 2002-2003, nota de rodapé 40, p. 33).
} 
cabível. São virtudes importantes em quem detém poder público exercido em nome do povo $^{113}$. Entretanto,

(...) subsistem muitas disputas nas quais ainda queremos a interferência de uma corte para barrar as ações de uma maioria legislativa, sem que ela esteja necessariamente violando nenhuma das premissas de Waldron sobre as instituições democráticas fundadas em nossa visão mais ampla de liberalismo e constitucionalismo ${ }^{114}$.

\subsection{Frederick Schauer e a "Constituição modesta"}

Nessa seara, investigando as nuances de um modelo menos invasivo de jurisdição constitucional, Frederick Schauer identifica a chamada "constituição negativa"115. Ela ganha vida quando certas decisões são proferidas, decisões essas que, ao invés de cuidar das aspirações, dos ideais e dos objetivos mais profundos e primeiros de uma comunidade política, servem para consolidar valores de longo prazo, que se encontram vulneráveis em curto prazo. A constituição negativa encerraria, assim, espécies de limitações constitucionais de segunda ordem voltadas a orientar decisões políticas ou judiciais de primeira ordem.

Para exemplificar o que seriam essas restrições constitucionais de segunda ordem a dar vida à constituição negativa, incidindo como limite a decisões de primeira ordem (decisões muitas vezes sábias e bem intencionadas), Schauer cita alguns casos julgados pela Suprema Corte americana.

O primeiro deles é Palmore v. Sidoti, decisão unânime que declarou inconstitucional - sob pena de violação da cláusula de igual proteção - que um juiz considerasse, em uma disputa de guarda de menor, o efeito que teria sobre a criança o segundo casamento de um dos pais com uma pessoa de "raça” diferente. Quaisquer que fossem as consequências, para a criança, de fazer parte de uma família inter-racial, a Corte estabeleceu que não cabia a um juiz, atuando em nome do Estado, considerá-las na decisão sobre a guarda. Não há indicação, segundo Schauer, de que a decisão sobre a guarda apresentasse motivações racistas. O juiz talvez só estivesse buscando evitar submeter a

\footnotetext{
113 Cf. WHITTINGTON, Keith E. Constitutional Interpretation: Textual Meaning, Original Intent, and Judicial Review. University Press of Kansas, 1999.

${ }^{114}$ WHITTINGTON, 2002-2003, p. 33, tradução minha.

115 SCHAUER, 2004, p. 1055, tradução minha.
} 
criança a dificuldades advindas da falta de aceitação social que um casamento inter-racial enfrentava nos Estados Unidos em 1983.

Contudo, no centro da decisão da Suprema Corte em Palmore estava a crença de que, mesmo diante de motivações benignas sustentando a decisão original sobre a guarda, ela seria constitucionalmente inviável. Por mais bem intencionado que estivesse o juiz, por mais sincera que fosse sua crença de que a decisão seria no melhor interesse da criança, e por mais que de fato fosse no melhor interesse da criança, a decisão não poderia se sustentar. Se raça é uma classificação suspeita, concluiu a Corte, então se presume que seu uso como critério é proibido não apenas quando reflete racismo, mas também quando não reflete $^{116}$.

Em outra série expressiva de casos em 1977 e 1978 conhecidos como a “controvérsia de skokie”, tudo começou quando o Partido Nazista americano planejou uma marcha nazista em Skokie, Illinois. A cidade está no subúrbio de Chicago e era habitada em sua maioria por sobreviventes do holocausto, razão perversa por que foi escolhida para sediar a manifestação. O prefeito e outros oficiais de Skokie tentaram por todos os meio possíveis barrar o evento, negando autorizações e impondo onerosas condições relativas a seguros, entre outras medidas. Cortes federais e estaduais decidiram que tais medidas, ainda que destinadas a proteger a população de Skokie contra um mal, violavam a primeira emenda constitucional (que protegeria a liberdade de expressão), com o que concordou a maioria da Suprema Corte, negando inclusive a apreciação completa do mérito por ausência de questão federal naquela série de casos locais. Aqui é fácil enxergar que os agentes públicos da cidade não agiram com motivos egoístas ou levianos, o que, ainda assim, não logrou tornar sua atuação constitucional.

Finalmente, em Griffin v. California, julgado pela Suprema Corte americana em 1965, foi declarado inconstitucional o ato do promotor público de lançar, em sua argumentação final, a observação de que réus culpados se negavam a testemunhar com mais frequência que aqueles inocentes, e pedir que o júri levasse isso em consideração, já que o réu naquele caso específico havia se negado a testemunhar. Mesmo se tratando de uma conclusão plausível, razoável e permitida em alguns países de Common Law que também reconhecem a garantia da não autoincriminação, a Suprema Corte decidiu que permitir esse comentário seria negar funcionalidade ao direito constitucional de não se autoincriminar, inibindo o uso futuro desse direito por outros réus em processos criminais.

116 SCHAUER, 2004. 
Nos julgados empregados como exemplo, o que não se deve perder de vista, insiste Schauer, é que nenhum dos principais agentes governamentais envolvidos - o juiz que decidiu sobre a guarda em Palmore, a prefeitura de Skokie e o promotor de Griffin - eram maus funcionários em busca de mais poder, ou de destorcer o poder que já possuíam. Eram, ao que tudo indica, agentes públicos honestos e bem intencionados realizando decisões políticas de primeira ordem destinadas a servir interesses legítimos da sociedade. As decisões, todavia, incorreram em violações constitucionais.

Na reflexão de Schauer, o fato de que tais oficiais estivessem a tomar decisões legítimas de primeira ordem não leva à conclusão de que eram decisões constitucionais. É por isso que legitimidade, honestidade e validação pública de decisões de primeira ordem não as protegem contra invalidações baseadas em considerações de segunda ordem denominadas 'constitucionais'. A ação governamental em cada um desses casos foi invalidada não para prevenir um mal ou combater oficiais sedentos por poder, mas para proteger importantes valores de segunda ordem, em longo prazo, e evitar que sejam limados por pessoas boas tomando decisões razoáveis em curto prazo ${ }^{117}$.

São, por certo, decisões de segunda ordem que podem estar fundamentadas em uma variedade de justificativas. Para aqueles que acreditam que bem-estar e maximização da utilidade não são os únicos objetivos dos valores humanos, algumas dessas restrições proibição de penas cruéis, proteção do livre exercício da religião, garantia de igual proteção legal, liberdade de expressão - podem ser consideradas limites deontológicos à maximização da utilidade. Mas também de uma perspectiva consequencialista e utilitarista, essas restrições ainda podem ser compreendidas como limites consequencialistas de ordem legal à maximização consequencialista de atos coletivos.

Sob quaisquer das visões substanciais que se adote, contudo, tem-se que os valores, os direitos, e os procedimentos protegidos pela constituição negativa não são necessariamente os mais importantes de todos, nem constituem uma declaração compreensiva dos ideais e esperanças fundamentais da raça humana, mas são os interesses que parecem correr maior risco no processo de decisões de primeira ordem, em curto prazo.

Reconhecer essa versão “negativa” da constituição não diz nada sobre o papel das Cortes. O próprio povo poderia, segundo Kramer, reconhecer e se “autoimpor” restrições legítimas de segunda ordem em suas próprias preferências políticas legítimas de primeira 
ordem. Por meio de autocontrole, eles poderiam obrigar esse limites de segunda ordem contra seus próprios interesses a curto prazo enquanto tomam suas decisões políticas de primeira ordem - diretamente ou por meio de representantes eleitos. E schauer reconhece isso.

Ainda assim, embora seja teoricamente possível que o povo imponha regras sobre si mesmos ${ }^{118}$, preocupações de ordem prática prevalecem na argumentação de Schauer, para quem é sempre prudente e aconselhável atribuir a terceiros algum tipo de poder supervisional sobre o cumprimento de limites determinados, além daqueles que se autoimpõe o próprio agente. Nesses termos:

(...) em inúmeras jornadas na vida, nos preocupamos quanto à força de vontade humana e a separação mental que faz isso possível. Não permitimos que juízes ou jurados participem de casos em que interesses seus estejam envolvidos. Indicamos inspetores gerais e divisões de controle interno com consultores especiais para evitar que oficiais investiguem a si mesmos. Esperamos que agentes públicos evitem conflitos de interesse, independentemente de quão honestos acreditamos que sejam. E em muitas outras instâncias, o princípio inglês do juiz natural - nemo debet esse judex in propria causa (no man should be judge of his own cause) - compõe os princípios do design institucional ${ }^{119}$.

Argumentos a favor de uma leve e moderada revisão judicial, para os fins descritos acima, portanto, não dependem, na visão de Schauer, de um panorama em que o povo ou os agentes públicos designados para atuar em seu nome (Legislativo, Executivo e Judiciário) aparecem como figuras estúpidas, ignorantes, egoístas, ou puramente movidas pela paixão em lugar da razão - costuma ser um erro, nesse sentido, argumentar por meio da "psicologização" do oponente. Tampouco dependem de uma visão glorificada do Poder Judiciário e dos juízes que o compõem.

O ponto central da teoria de Schauer, que para ele divide a doutrina entre aqueles que defendem e aqueles que são céticos quanto ao poder judicial de revisão constitucional, é o papel da própria Constituição no sistema de adjudicação de direitos. Para ele, a Constituição não é o fórum primeiro onde o povo deposita o núcleo de suas decisões mais importantes sobre política e princípios.

${ }_{119}^{118}$ Cf. SCHELLING, Thomas C. Enforcing Rules on Oneself. 1 J.L. Eco. \& Org. 357, 1985.

${ }^{119}$ SCHAUER, 2004, p. 1057, minha tradução. 
Para teóricos do constitucionalismo desde 1970, a Constituição é a religião civil de uma nação, definindo e afinando quem ela é e quem deseja ser, cristalizando os sonhos e medos principais de uma comunidade. Trata-se de uma visão fértil para que nasça a desconfiança quanto à supremacia judicial. Se a Constituição é tão central à identidade do povo, sendo o veículo para a formação e transformação do espírito de uma nação, então deixar referida definição nas mãos de juízes não eleitos, em um governo democrático, vira uma fonte de problemas.

Já consoante a visão propugnada por Schauer - uma visão modesta, em seus termos -, a constituição, apesar de definir a estrutura básica de governo e delinear as regras procedimentais do aparato estatal, diz muito pouco sobre o que esse governo deve fazer, e é assim que deve ser ${ }^{120}$. Decisões substantivas sobre política pública devem ser tomadas em arenas mais representativas, em fóruns mais deliberativos, sejam eles as legislaturas ou as redes mais difusas por meio das quais a opinião pública é formada, reformada e implementada. A constituição modesta, nesse contexto, é apenas uma coadjuvante, e não a protagonista.

Acreditar na constituição modesta, logo, não é discordar dos constitucionalistas quanto ao locus primário de definição das principais questões de política pública. É, ao contrário, discordar da noção de que, quando o povo finalmente decide tais questões, o debate deva ser canalizado por meio da Constituição.

E ainda que a constituição modesta não aspire a ser o centro de todos ou da maioria dos debates sobre política ou princípios, subsistem boas razões para que um regime de governo limite a soberania legislativa, ou mesmo a soberania popular. Não porque exista algo errado com o povo, mas porque indivíduos informados e bem intencionados perseguindo ações políticas igualmente informadas e bem intencionadas podem precisar de limites externos que garantam o bem comum agregado. Aí tem lugar o papel da constituição modesta, e contanto que siga focada em tais limites negativos, é pequeno o

\footnotetext{
${ }^{120}$ É certo que, quando formula sua proposição acerca da função modesta da constituição, Schauer guarda em mente o sistema jurídico americano, com suas feições específicas, e chega mesmo a considerar a própria visão dos framers quando formularam a constituição do país. Sobressai, contudo, seu esforço de afastar-se das premissas que um ou outro sistema legal estabelece, para obter uma teoria não histórica, mais preocupada com as conclusões possíveis do que com as premissas das quais partir: "The antecedent question is whether we see the Constitution as the vessel into which much of the shape of the nation is poured, or from which much of that shape emerges, or by contrast whether we see the Constitution as more modestly being about the development of a certain category of side-constraints on the political process. It may be that choosing the latter produces the conclusion that the Constitution is best treated as ordinary law, and it may even be that the conclusion that the framers and others did not view the Constitution as ordinary law produces some historical support for the former. But if the question is the largely nonhistorical one of institutional design, the Constitution as ordinary law (or not) is at best the conclusion rather than the premise" (SCHAUER, 2004, nota de rodapé 99, p. 1065, minha tradução).
} 
perigo de que uma Suprema Corte forte e atuante na interpretação da Constituição represente o enfraquecimento do governo democrático.

Na conclusão de Schauer, se o constitucionalismo for equiparado à capital questão de se alocar decisões sobre os valores e ideais fundamentais de uma sociedade, então a ideia de supremacia judicial é sim um ataque ao autogoverno, terminantemente inconsistente com a maioria das versões de governo democrático. Se é, por outro lado, considerado mais modestamente, não cuidará de noções grandiosas de identidade nacional ${ }^{121}$ : “é, em sua dimensão mais importante, sobre a forma como o autogoverno não é somente sobre o governo mas sobre o “auto”’122. É sobre a importância de limitar, bem como conferir poder, na busca pelo interesse próprio. As ambições da constituição modesta são discretas em seu objetivo, mas extraordinárias em sua força, permitindo espaço para a revisão judicial e para a democracia.

\subsection{Argumentos centrais da doutrina}

Contra a revisão judicial e a favor da supremacia legislativa, alguns são os argumentos empregados pelos doutrinadores. Conrado Hübner Mendes os compilou e elencou um a um (os mais relevantes), não sem antes esclarecer que "não defendem propriamente a extinção da atividade jurisdicional em matéria de interpretação constitucional, mas não admitem que a construção do significado da constituição possa ser dominada pela corte” ${ }^{\Perp 23}$.

\footnotetext{
${ }^{121} \mathrm{E}$ mais além da própria identidade nacional, ele afasta também pretensões de que o instrumento sirva de base moral. Confira-se: "It is not even about what Alexander Bickel called 'enduring values'. Rather, in its most important dimension, it is about the way in which self-rule is not only about rule but about self. And if in numerous other dimensions of life we recognize the importance of constraining as well as empowering the pursuit of self-interest, we should not be appalled that this dimension of institutional design might be reflected in the design of democracy. When we recognize the importance of second-order constraints on firstorder democratic preferences of both policy and principle, then constitutionalism in this more modest sense comes to the fore. The modest Constitution has ambitions that are narrower in scope but greater in force, and as a result judicial supremacy and the modest Constitution emerge as natural partners" (SCHAUER, 2004, p. 1067)

${ }^{122}$ SCHAUER, 2004, p. 1067, minha tradução.

${ }^{123}$ MENDES, 2011, pp 95-96.
} 
1.4.1 A corte não protege as precondições da democracia, pois não está fora da política.

O primeiro deles está assim enunciado: “A corte não protege as precondições da democracia, pois não está fora da política” ${ }^{124}$. Os que defendem essa posição apontam duas falácias utilizadas pela chamada teoria constitucional.

A primeira seria a de que o conceito de democracia que defende a prevalência do legislador na solução de dilemas morais coletivos reveste-se de mero procedimentalismo, baseado em uma visão amoral de democracia. Nas palavras de Waldron: “Estou cansado de ouvir opositores da revisão judicial serem denegridos como céticos em relação a direitos. A melhor resposta é sustentar uma teoria contra a revisão judicial baseada em um forte comprometimento com direitos” ${ }^{125}$. Confunde-se, pois, teoria da autoridade com teoria da justiça. É plenamente possível, nesse contexto, construir uma noção substantiva de democracia e, ao mesmo tempo, garantir que o legislador seja o responsável pela obtenção dessas metas. Ao se negar a possibilidade de que o Judiciário exerça o controle externo sobre o Parlamento, não se está a afirmar que o Parlamento possa decidir o que bem entenda ${ }^{126}$.

A segunda seria a visão das Cortes como agentes afastados do conflito ideológico e por isso detentores de respostas certas na proteção de direitos ${ }^{127}$. A Corte, argumenta-se, nunca esteve fora da política, especialmente quando se observa quão controversas são as posições possíveis na interpretação da constituição. Por isso mesmo é de se notar que o desacordo persiste, de modo que a Corte apenas adiciona uma interpretação possível, adornada com linguagem aparentemente técnica, escondendo a manifestação de vontade e de agendas ideológicas ${ }^{128}$.

\footnotetext{
${ }^{124}$ MENDES, 2011, p. 96.

${ }^{125}$ WALDRON, 2006, p. 1366, tradução minha.

126 WALDRON, 1999.

127 Cf. DWORKIN, Ronald. Freedom `s Law: a Moral Reading of the American Constitution. Cambridge: Harvard University Press, 1996.

${ }^{128}$ Essa visão foi bastante explorada pelas escolas americanas do realismo jurídico (anos 20 e 30) e dos estudos jurídicos críticos (anos 70 e 80).
} 
1.4.2 A corte não protege direitos de minorias: moralmente, isso é controverso; empiricamente, isso é falso.

Outro esforço de ataque às Cortes vem assim resumido por Hübner Mendes: “ $A$ corte não protege direitos de minorias: moralmente, isso é controverso; empiricamente, isso é falso" ${ }^{129}$.

A falácia por trás da argumentação estaria em usar a retórica da maioria sem oposição para caracterizá-la como figura invariavelmente tirânica. O fato de que uma minoria possa perder no Parlamento, ainda que com frequência, não equivale ao domínio necessário da tirania. Waldron admite que pode haver, porventura, uma tirania imposta por uma maioria, mas alerta que essa não será a regra - pode haver um desacordo moral razoável e sincero entre pessoas que levam direitos a sério. Situação de desacordo, por isso, não é sinônimo de tirania da maioria.

Haverá sim o risco de domínio tirânico apenas quando as maiorias tópicas se alinham às maiorias decisórias ${ }^{130}$. É dizer, somente quando uma minoria decisória - os que votam na decisão - coincide sistematicamente com a minoria tópica - os que serão atingidos pela decisão -, é que haverá, para Waldron, sinal da real existência de uma minoria insular e separada, em risco de sofrer a tirania da maioria ${ }^{131}$. Porque, em regra e em condições normais, pessoas que levam direitos a sério tomam posição independentemente de se beneficiarem ou de se prejudicarem pessoalmente com a decisão. Direitos, portanto, continuam a ser a linguagem político-moral dominante, mas dentro de uma instituição que respeite o igual status de agente moral autônomo de cada cidadão.

Muito mais importante, para Waldron, é o conceito substantivo inerente à ideia de tirania, e não o procedimental. A tirania, assim, estará instituída toda vez que decisões erradas sobre direitos forem tomadas. Corte e Parlamento podem ambos atuar de forma tirânica, independentemente do procedimento que adotam.

Quanto ao aspecto empírico, sustenta-se que as Cortes não conseguem resistir por muito tempo, pois uma maioria consistente não demora a vencer ${ }^{132}$. E ainda assim, até que a maioria vença de fato, nada impede que a Corte submeta o regime a uma tirania da

\footnotetext{
${ }^{129}$ MENDES, 2011, p. 97.

${ }^{130}$ WALDRON, 2006.

${ }^{131}$ WALDRON, 2006.

132 Cf. DAHL, Robert. Decision-Making in a Democracy: The Supreme Court as a National Policymaker. Journal of Public Law, v. 6, 1957.
} 
minoria, por ser uma instituição elitista em busca da preservação de seus interesses nem sempre coincidentes com os da sociedade ${ }^{133}$.

1.4.3 A Corte não é emissária do poder constituinte nem mecanismo de précomprometimento. Esse é um disfarce que encobre um agente político que faz escolhas morais controversas.

O terceiro argumento vem na seguinte forma: “A Corte não é emissária do poder constituinte nem mecanismo de pré-comprometimento. Esse é um disfarce que encobre um agente político que faz escolhas morais controversas” ${ }^{134}$.

Aqui a lógica do pré-cometimento é atacada ao argumento de que, embora tenha se comprometido a respeitar certos valores abstratos, o povo não se posicionou sobre suas implicações concretas, que geram desacordos sobre os quais o povo deve continuar decidindo. Juízes não estão apenas a respeitar as decisões constituintes originais, mas indo além para tomarem suas próprias decisões em temas controversos.

O dualismo constitucional observado na lógica do pré-comentimento traria também concepção de política na qual o cidadão somente é instado a manifestar preocupação com o bem comum em momentos rápidos e esporádicos. Assim afirma Hübner Mendes:

\begin{abstract}
Uma democracia vibrante, no entanto, precisa da participação não apenas nos raros momentos constitucionais. $\mathrm{O}$ fato de a fundação constitucional ter sido democrática, ademais, não diz nada sobre o produto desse processo. Dito de outro modo, não se pode dizer que a revisão judicial é democrática porque um poder constituinte democrático a aprovou. Ele pode aprovar toda sorte de regime, dos mais aos menos democráticos. O fato de o 'criador' ser formalmente democrático não significa que a 'criatura' também o será ${ }^{135}$.
\end{abstract}

1.4.4 A Corte, de fato, pode ter sua decisão rejeitada, ao final, pelo poder de emenda ou por uma nova constituição. Essa dificuldade, porém, não se justifica.

Pode-se ainda resumir outro argumento usualmente utilizado contra a jurisdição constitucional da seguinte forma: "A Corte, de fato, pode ter sua decisão rejeitada, ao

${ }^{133}$ Cf. BORK, Robert. Neutral principles and some first amendments problems. Indiana Law Journal, n. 47, 1971.

${ }^{134}$ MENDES, 2011, p. 98.

${ }^{135}$ MENDES, 2011, p. 98. 
final, pelo poder de emenda ou por uma nova constituição. Essa dificuldade, porém, não se justifica" ${ }^{136}$.

Os que lançam mão dessa crítica acreditam que uma dificuldade tamanha como é a de emendar uma constituição ou mesmo mobilizar todo um processo de renovação na base institucional de uma sociedade com vistas à fundação de uma nova ordem constitucional viola a igualdade pressuposta na regra da maioria. A democracia não serve apenas para momentos de exceção, com a manifestação do povo dando-se somente na forma de "válvulas de escape”"137. A atividade política em regime de autogoverno deve ser permanente.

1.4.5 A revisão judicial não é decorrência necessária do estado de direito e não deve ser exclusividade na interpretação da constituição. Interpretações do Parlamento podem prevalecer.

A quinta crítica à revisão judicial está assim redigida: “A revisão judicial não é decorrência necessária do estado de direito e não deve ser exclusividade na interpretação da constituição. Interpretações do Parlamento podem prevalecer"138.

Trata-se das mesmas inconsistências lógicas na famosa decisão Marbury $v$. Madison já apontadas no capítulo anterior ${ }^{139}$. Não há fundamentação lógica no raciocínio segundo o qual, para ser suprema, a Constituição deve ser resguardada pela revisão judicial. Caso assim fosse, leis inconstitucionais jamais poderiam sobreviver e continuar obrigando seja por não terem sido questionadas perante a Corte, seja por erro judicial - o que ficou conhecido como a "falácia de Marshall"140. A natureza normativa do Direito e da Constituição não dependem da existência de uma instituição a aplicar sanções em caso de violações.

Não sendo por necessidade lógica do sistema, a opção por adotar a o instituto da revisão judicial pode ser atribuída a razões de conveniência prática, para maximizar a eficácia do Direito Constitucional. Não significa, contudo, subestimar a capacidade de

\footnotetext{
${ }^{136}$ MENDES, 2011, p. 99.

${ }^{137}$ MENDES, 2011, p. 98.

${ }^{138}$ MENDES, 2011, p. 99.

${ }^{139}$ Cf. Nota de rodapé n. 66, capítulo 1.

140 NINO, 1996, p. 192.
} 
outras instituições, no regime de governo democrático, de produzir interpretações constitucionais de qualidade e representatividade.

1.4.6 A Corte não é um agente externo que julga com imparcialidade, pois não está fora da política. Alguém precisa decidir por último, e nenhum dos possíveis candidatos a essa autoridade será neutro.

Voltando à questão da neutralidade dos agentes envolvidos na definição de direitos, tem-se o sexto argumento compilado por Hübner Mendes, de que “A Corte não é um agente externo que julga com imparcialidade, pois não está fora da política. Alguém precisa decidir por último, e nenhum dos possíveis candidatos a essa autoridade será neutro" ${ }^{141}$.

Aqui o novo professor do Largo São Francisco é claro em diferenciar duas situações em que age um magistrado - aquela em que atua como um terceiro não interessado, para solucionar conflitos entre dois indivíduos, e aquela do controle de constitucionalidade. É direcionada à segunda espécie a crítica acima referida, dado que nela não se pode afirmar a existência de uma autoridade na condição de terceiro não interessado. Os efeitos de sua decisão, como bem se sabe, atingem a sociedade como um todo - inclusive ele próprio. E muito embora se chegue a uma determinação prática sobre a posição que prevalece, o desacordo continuará a existir. De acordo com Waldron: “A necessidade de uma determinação não faz desparecer o desacordo; ao contrário, significa que uma base comum para ação tem que ser forjada no calor dos nossos desacordos”142.

Assim é que para os opositores da revisão judicial essa autoridade responsável por forjar um entendimento deve ser o Parlamento, pelo valor moral em que se funda e por sua capacidade de encontrar soluções mais equilibradas para os temas controversos. Relembra Hübner Mendes que:

Vale, aqui, a mesma resposta contra o refrão da 'tirania da maioria': numa sociedade que leva direitos a sério, mas que discorda sinceramente sobre sua aplicação, não há nada de necessariamente tirânico na maioria que desqualifique o parlamento e qualifique a corte $\mathrm{e}^{143}$.

\footnotetext{
${ }^{141}$ MENDES, 2011, p. 99.

${ }^{142}$ WALDRON, 2006, pp. 1370-1371, tradução minha.

${ }^{143}$ MENDES, 2011, p. 100.
} 
1.4.7 O controle de constitucionalidade não é mera decorrência da dinâmica da separação de poderes. Não há razão para que tenha a última palavra.

Como sétima crítica, tem-se: "O controle de constitucionalidade não é mera decorrência da dinâmica da separação de poderes. Não há razão para que tenha a última palavra” ${ }^{144}$.

Os responsáveis por essa ideia de oposição não tentam negar a importância da separação de poderes como hoje a conhecemos, nem os mecanismos de freios e contrapesos a que se sujeita a atividade legislativa. Contudo, eles enxergam a necessidade de que recaia, ao final, sobre uma instituição específica a responsabilidade pela última palavra para dúvidas sobre a Constituição - para eles, o desenho institucional encartado na própria Constituição elegeu o Parlamento para tanto. A interferência da Corte nesse processo leva à distorção da política pública por meio da perda da racionalidade original buscada pelo legislador, bem como à debilitação da democracia ${ }^{145}$.

1.4.8 No controle de constitucionalidade, a Corte não analisa exatamente um caso concreto diferente dos casos concretos que informam a deliberação de uma lei.

A embasar outras teorias opositoras, encontra-se o seguinte raciocínio: “No controle de constitucionalidade, a Corte não analisa exatamente um caso concreto diferente dos casos concretos que informam a deliberação de uma lei" ${ }^{146}$.

Nessa esteira de argumentação, existiriam suposições errôneas na teoria de quem defende a revisão judicial com arrimo na diferença do caso concreto que dá ensejo ao controle de constitucionalidade - de que as Cortes têm sempre completo entendimento da concretude de um caso, ao passo que o legislador não levaria em conta a diversidade de casos reais ao legislar.

Os defensores do Parlamento vêm, então, afirmar não ser raro que as Cortes estejam menos informadas que o Parlamento, já que este dispõe de inúmeros recursos para angariar informações de grupos sociais variados, tendo inclusive melhor noção do impacto

\footnotetext{
${ }^{144}$ MENDES, 2011, p. 100.

${ }^{145}$ TUSHNET, Mark. Policy Distortion and Democratic Debilitation: Comparative Illumination of the Counter-Majoritarian Difficulty, Michigan Law Review, v. 94, 1995.

${ }^{146}$ MENDES, 2011, p. 100.
} 
da lei pelas experiências legislativas anteriores referentes ao mesmo tema. A Corte continuará a função de adaptar a lei às circunstâncias concretas que mudam sem cessar, o que não significa que possa simplesmente revogá-la.

Waldron reconhece que haverá certas ocasiões em que o legislador pode encontrar maior dificuldade para apreender a dimensão de direitos fundamentais em uma lei envolvendo considerações de muitos outros tipos. Para remediar esse risco, bastaria um modelo "fraco" de revisão judicial, para evidenciar o problema da constitucionalidade sem tirar do legislador o poder de revogar a lei ${ }^{147}$.

1.4.9 A Corte é igualmente falível em questões de princípio, e pessoas discordam sobre respostas corretas.

Eis outra linha de argumentação: "A Corte é igualmente falível em questões de princípio, e pessoas discordam sobre respostas corretas"148.

Seria exageradamente idealizada a visão de que a Corte tem melhor capacidade para deliberar sobre princípios. Supõe-se, nas teorias que contam com essa capacidade aprimorada, um maior preparo por parte dos agentes que compõem a Corte e também um ambiente institucional isolado de pressões eleitorais.

Para rebater o ponto relativo à expertise, pode-se argumentar que questões de princípios não são ciências neutras e técnicas, mas sim disputas no campo normativo e ideológico. Nesse sentido, escolhas morais realizadas por Cortes não seriam mais qualificadas que aquelas formalizadas por legisladores que levam direitos a sério. Quanto ao temo do isolamento, ou "insulamento", Cass Sunstein acredita que "do ponto de vista moral, insulamento de pressões da maioria às vezes é um problema, e não uma solução" ${ }^{149}$.

\footnotetext{
${ }^{147}$ WALDRON, 2006.

${ }^{148}$ MENDES, 2011, p. 101.

149 SUNSTEIN, Cass. Testing minimalism: a reply. Michigan Law Review, v. 104, 2005, p. 128, minha tradução.
} 
1.4.10 A Corte não promove uma representação deliberativa ou argumentativa. Juízes não representam, não são eleitos, e sim uma elite profissional.

Retomando a questão da idealização do Judiciário, segue a próxima crítica: “A Corte não promove uma representação deliberativa ou argumentativa. Juízes não representam, não são eleitos, e sim uma elite profissional” ${ }^{\text {"150. }}$.

A argumentação dirige-se aqui às teorias que apontam a Corte como a "representante da razão", ao passo que o Parlamento seria mero "representante da agregação". Trata-se de simplificação que se faz da ideia de representação por trás do Poder Legislativo, quando na realidade cuida-se de fenômeno muito mais rico que sua simples modalidade eleitoral. Esclarecendo a premissa de que parte essa linha de raciocínio, assim declara Hübner Mendes:

A suposição da super-racionalidade judicial é uma obsessão dos teóricos normativos, mas já foi seguidamente desmistificada por diferentes correntes que, animadas pelo benefício da dúvida, deram mínima atenção a evidências empíricas $^{151}$.

1.4.11 A Corte não é instituição educativa, nem promove um debate público melhor do que o legislador. Está presa a uma linguagem empobrecida, verborrágica, inflexível e amarrada a tecnicalidades jurídicas.

O cerne da seguinte construção segue na análise mais detida sobre a qualificação dos Tribunais: "A Corte não é instituição educativa, nem promove um debate público melhor do que o legislador. Está presa a uma linguagem empobrecida, verborrágica, inflexível e amarrada a tecnicalidades jurídicas"152.

A ideia de superioridade da razão pública exercida pelas Cortes está apoiada na premissa de que o legislador, diferentemente do juiz, não justifica suas decisões. Segundo Waldron, existe expressiva qualidade argumentativa nos registros de debates parlamentares, mas a diferença é que juristas são treinados para estudar as razões de decidir do judiciário, e não as razões do legislativo ${ }^{153}$.

\footnotetext{
${ }^{150}$ MENDES, 2011, p.

${ }^{151}$ MENDES, 2011, p. 101.

${ }^{152}$ MENDES, 2011, p. 102.

${ }^{153}$ WALDRON, 2006.
} 
Ademais, atribui-se à Corte uma pretensa qualidade deliberativa, inexistente quando se têm em conta os modelos ideais de discussão democrática de temas controvertidos. O padrão de argumentação judicial da Corte polariza e divide opiniões, não pacifica, que é justamente o que preconiza a boa deliberação moral. Erige, pois, vencedores e perdedores, presa a uma retórica adversarial, típica da linguagem dos direitos $^{154}$. Extremos restam imoderados e posições em disputa não são acomodadas na forma de concessões intermediárias.

Gerald Rosenberg, na contramão da grande celebração em torno de Brown v. Board of Education, vislumbrou papel reduzido da Suprema Corte americana na integração racial nos EUA durante a década de 60, atribuindo-lhe, ao revés, a responsabilidade pela despolitização de conflitos e, como consequência, desmobilização e neutralização de movimentos de mudança ${ }^{155}$.

Para além da rigidez no discurso, a Corte enfrenta o problema da verborragia, apresentando argumentação judicial legalista e hermética. A preocupação principal concentra-se na semântica e não nos valores em jogo - no jargão, e não no argumento em si. Juízes dispersam o raciocínio em argumentos laterais relativos à própria argumentação jurídica, enquanto o conflito de fundo, que merece apreciação aberta e franca, resta escamoteado em digressões retóricas.

Conclui Hübner Mendes:

Se tudo isso for verdade, a proposta de que ela (a corte) possa cumprir uma função educativa e ensinar como argumentar sobre questões constitucionais essenciais não passa de mais uma fetichização engendrada pela teoria normativa ${ }^{156}$.

Sunstein utiliza a decisão no caso Roe $v$. Wade como exemplo do efeito nefasto de uma decisão judicial no processo de deliberação pública. Para ele, a decisão sufocou a política e bipolarizou a sociedade americana na discussão de um tema que vinha recebendo soluções criativas por parte da legislação que regulava o aborto. O tema teria sido extraído

\footnotetext{
${ }^{154}$ KNOPFF, Rainer. Courts Don`t Make Good Compromises. Policy Options, April, 1999.

155 ROSERNBERG, Gerald. “The Hollow Hope: Can Courts Bring About Social Change?” Chicago: University of Chicago Press, 1993.

${ }^{156}$ MENDES, 2011, p. 102.
} 
do foro de negociação pública e transformado numa questão rígida e binária de princípio $^{157}$.

Waldron também não deixou de notar que, no texto da decisão, muitas páginas são dedicadas a discutir sobre a aplicabilidade de precedentes ao caso, mas apenas alguns parágrafos cuidam da importância moral de direitos reprodutivos ${ }^{158}$. Tal postura teria atrapalhado a que a sociedade considerasse os reais argumentos em oposição, desviando o foco para questões legais de nenhuma relevância moral.

1.4.12 A Corte integra um sistema democrático, mas não deve ter a última palavra.

Há ainda a linha de considerações que, firmes no sistema da separação de poderes, propugnam que "A Corte integra um sistema democrático, mas não deve ter a última palavra” ${ }^{159}$.

A democracia, por óbvio, não pressupõe que todos decidam tudo o tempo todo. As funções, bem por isso, são delegadas e distribuídas em uma rede intrincada. Deve haver, contudo, algum tipo de hierarquização interna, com decisões moralmente detentoras de maior autoridade do que outras, proferida por uma instituição classificada como a autoridade máxima. Ainda que se reconheça que a legitimidade democrática do regime deva ser pensada em bloco, dentro desse bloco haverá instituições mais e menos democráticas. Por meio dessa análise, atribui-se a última palavra, então, ao legislador.

1.4.13 A Corte é composta de membros indicados por autoridades eleitas, mas este mecanismo não é suficiente para a prestação de contas democrática.

Ressalte-se, finalmente, a réplica ao argumento da legitimidade indireta conferida aos membros das Cortes por meio de indicações, assim apresentada: "A Corte é composta de membros indicados por autoridades eleitas, mas este mecanismo não é suficiente para a prestação de contas democrática" ${ }^{160}$.

\footnotetext{
${ }^{157}$ SUNSTEIN, Cass. One Case at a Time: Judicial Minimalism on the Supreme Court. Cambridge: Harvard University Press, 2001.

${ }^{158}$ WALDRON, 2006.

${ }^{159}$ MENDES, 2011, p. 103.

${ }^{160}$ MENDES, 2011, p. 103.
} 
Não se está a negar a conexão dos membros das Cortes com autoridades eleitas, mas tampouco se pode ignorar tratar-se de um liame muito remoto. Considerando que a medida da legitimidade está na comparação, é preciso comprovar que a autoridade dona da última palavra seja mais democrática que as demais existentes, e tal não seria o caso do Judiciário.

Na tentativa de esboçar um apanhado que resuma com acuidade a razão central das teses que defendem o Parlamento como a instituição detentora da última palavra sobre direitos, Hübner Mendes traça um panorama geral dos mais elucidativos:

Parlamentos devem decidir por último sobre direitos pela mescla de razões morais e instrumentais esboçadas acima. Do ponto de vista moral, o parlamento é uma instituição valiosa tanto por representar o povo (e potencializar a dinâmica deliberativa que o distanciamento representativo permite) quanto por dar a cada indivíduo igual importância. Num contexto de desacordo, todos devem ter a igual possibilidade de participar do processo de resolução, em vez de delegar a uma elite. Democracia, de fato, tem precondições, mas elas não se realizam senão pela estratégia institucional de representação e da regra da maioria ${ }^{161}$.

\section{Do outro lado das trincheiras: as Legislaturas sob ataque}

\subsection{A Supremacia do Parlamento inglês e a teoria do modelo de revisão judicial do Common Law}

Na Inglaterra, a supremacia do Parlamento é chamada de “soberania parlamentar”. E isso porque, de acordo com Douglas E. Edlin, “(...), na Inglaterra, ser soberano é ser supremo, e ser supremo é ser poderoso de forma única” ${ }^{162}$. Construída ao longo de milhares de anos, a ideia, segundo Goldsworthy, é a de que há de haver poder absoluto, ilimitado e incontrolável situado em algum lugar em todo governo. A questão a se propor é onde seria mais seguro alocar tal poder. "Na Inglaterra”, responde Goldsworthy, “ele foi abrigado com os reis, lordes e comuns no Parlamento"163.

A predisposição inglesa de enxergar o poder governamental localizado em um único corpo institucional evoluiu, bem por certo, de sua História monárquica - legal e

\footnotetext{
${ }^{161}$ MENDES, 2011, pp 103-104.

162 EDLIN, Douglas E. From Ambiguity to Legality: The Future of English Judicial Review. 52 Am. J. Comp. L. 383 2004, p. 385, tradução minha.

163 EDLIN, 2004, p. 385, tradução minha.
} 
política -, como demonstra Goldsworthy por meio de extensa e meticulosa documentação ${ }^{164}$. O poder representado pela pessoa do monarca passou a ser representado pelo Parlamento, fundando-se a concepção de soberania parlamentar em que o Poder Judiciário encontrava-se subordinado ao Poder Legislativo.

Com efeito, a História legal inglesa repercutiu diretamente em sua teoria políticolegal. A tese de Thomas Hobbes de que todo sistema legal necessariamente pressupõe um law-maker soberano e a "teoria legal do comando" de John Austin ${ }^{165}$ foram essenciais para a construção de um sistema legal que conta com um poder soberano em seu ápice. Antecedentes dessa vinculação a um poder soberano legalmente ilimitado podem ser encontrados nos escritos de Bodin, e sua influência é vista no pensamento inglês contemporâneo de Dicey ${ }^{166}$.

E se é certo que a concepção Bodiniana-Austiniana-Diceyniana de soberania parlamentar domina a doutrina inglesa atual, é possível localizar alguns juristas e teóricos que vêm construindo críticas à concepção da soberania parlamentar como um dado inelutável da História política e legal inglesa. Trevor Allan, por exemplo, argumenta que o debate recorrente sobre a definição adequada de revisão judicial no Direito Constitucional inglês está a demonstrar um desacordo básico sobre as bases históricas e teóricas da soberania absoluta do Parlamento na prática e no pensamento ingleses ${ }^{167}$.

Nessa esteira, Edlin, jurista britânico, vem defender a ideia de que na teoria constitucional inglesa, já pode se localizar uma tendência surgindo: a aceitação do instituto da revisão judicial não como mero controle formal sobre delegação de poder aos agentes administrativos pelo Parlamento, mas como um poder autônomo, inerente ao próprio Common Law, independente do Parlamento e suas intenções ${ }^{168}$.

É certo que a concepção tradicional e ortodoxa de Judicial Review na Inglaterra assenta-se na premissa de que juízes podem rever atos administrativos apenas para assegurar que o órgão não excedeu a autoridade a ele delegada pelo Parlamento. Logo, as Cortes exerceriam seu poder de revisão judicial para evitar que agentes públicos atuem ultra vires, isto é, fora dos parâmetros de sua limitada autoridade. Assim é que para as

\footnotetext{
164 Cf. GOLDSWORTHY, Jeffrey. The Sovereignty of Parliament: History and Philosophy. Oxford: Clarendon Press, 1999.

${ }^{165}$ Essa teoria propõe um conceito de lei em torno da ideia de comandos direcionados ao "comandante sem comando".

${ }^{166}$ EDLIN, 2004, p. 386.

167 ALLAN, T.R.S. Law, Liberty, and Justice: The Legal Foundations of British Constitutionalism. 20 Oxford Journal of Legal Studies, 1993.

${ }^{168}$ EDLIN, 2004.
} 
tradicionais teorias ultra vires da revisão judicial, o processo tem início quando o Parlamento legisla e delega porções de autoridade a órgãos públicos em termos amplos, produzindo ambiguidade quanto ao contorno preciso da autoridade legítima do órgão. As Cortes, então, entram em ação para controlar desvios ou excessos no exercício dos poderes delegados. A função do Judiciário, pois, seria estaria limitada a resguardar as intenções do Parlamento supervisionando o exercício de poderes delegados por ele a autoridades administrativas.

Todavia, Edlin anuncia o início de novos caminhos na concepção teórica e mesmo prática da jurisdição constitucional na Inglaterra, com o surgimento de teorias defendendo o poder da revisão judicial como figura inerente ao Common Law, que não se limita a resguardar a vontade do Parlamento em atos delegatórios - cuida-se das teorias do modelo de revisão judicial do Common Law. Nesse sentido, alguns juízes ingleses já vêm deixando de lado a ambiguidade da lei como pré-requisito para a intervenção judicial em favor de uma visão mais ampla da revisão judicial, mais preocupada com a preservação de valores substantivos do Common Law do que com a vontade implícita dos legisladores. Uma doutrina da revisão judicial, portanto, em que princípios fundamentais do Common Law operam em um nível estrutural para equilibrar a distribuição dos poderes públicos e responsabilidades institucionais, auxiliando as Cortes na promoção e defesa de direitos individuais ameaçados por excessos na atuação do Estado ${ }^{169}$.

\subsection{Argumentos centrais da doutrina}

Ao contrário dos Parlamentos, as Cortes não se sobressaem como elemento natural da democracia. Para defender sua atuação à luz de um governo democrático, portanto, não se chega a arguir a inutilidade das legislaturas, mas sim sua insuficiência. A função do Parlamento como o único centro de poder legítimo para a realização das potencialidades do autogoverno é relativizada, e não suprimida, reservando-se às Cortes as não menos

\footnotetext{
${ }^{169}$ EDLIN, 2004. Eis a seguir trecho elucidativo de seu artigo: "Absolute parliamentary sovereignty and concomitant judicial subordination are neither historically inevitable nor constitutionally desirable. In fact, over three hundred years, the independence of the English common law judiciary has allowed it to develop and maintain English public law doctrines and values. England's authentic common law heritage has always recognized that judges must be capable of an amenable to an exercise of independent review of legislative and executive action to ensure the preservation of the rule of law"(EDLIN, 2004, p. 388).
} 
essenciais responsabilidades atinentes à proteção, preservação, potencialização (e variantes) do sistema institucional como um todo.

O legislador representativo, assim, segue sendo necessário, mas, nessa perspectiva de defesa da revisão judicial, não deverá ter a última palavra em direitos fundamentais. O mito da realização do autogoverno teria deturpado a capacidade de enxergar a realidade do Parlamento, promovendo a ilusão de que representantes eleitos pela maioria, ao decidirem também por maioria, estariam possibilitando igual impacto às preferências de cada e todo cidadão. A transição de ideais políticos a instituições, contudo, não seria operação assim tão simples - as estratégias institucionais implicadas no processo iriam muito além do Parlamento em si.

Os argumentos que apontam falhas no Parlamento costumam dividir-se entre os que alegam problemas na representação e os que atacam a regra da maioria diretamente. É assim que Conrado Hübner Mendes, aqui também, apresenta suas frases-sínteses para compilar as críticas e as linhas de argumentos gerias que propõem, bem como os autores representativos de cada ponto específico. No entanto, antes de passar para os argumentos compilados por Mendes, algumas palavras sobre o instituto da representação se mostram necessárias.

\subsection{A democracia representativa em foco}

Discorrer sobre a democracia representativa nos dias atuais é tarefa das mais ardilosas. Não há contornos definidos ou padrões unificados quando se investigam as bases eleitorais dos denominados governos democráticos. Nas palavras da Professora Monica Herman Caggiano,

(...) cada vez mais, até em razão do fenômeno expansionista, o teorema democrático traz inquietações. É que a sua aplicação oferece ao analista um vasto leque de nuanças e caracteres diferenciados. Discorrer sobre a democracia, profetiza Jean Gicquel, seria apresentar 'un mot qui chante', uma verdadeira deusa ${ }^{170}$.

170 CAGgIANO, Monica Herman. Democracia x Constitucionalismo - Um navio à deriva, artigo em homenagem ao Professor Celso Lafer, São Paulo, 2010. 
Estudos realizados pelos cientistas políticos Bernard Manin ${ }^{171}$ e Mark A. Kishlansky $^{172}$ acerca da origem do processo eleitoral inglês no século dezessete identificaram a correlação cronológica e estrutural entre três fenômenos políticos: a adoção do método eleitoral para a designação dos legisladores, a transformação dos eleitos de delegados em representantes, e o surgimento de alianças partidárias ou ideológicas entre os cidadãos. Nesse sentido, concluiu-se que o processo eleitoral, nos Estados modernos, estimulou dois movimentos cruciais para o processo de democratização: a separação entre sociedade e Estado e a dissociação dos candidatos de suas posições ou classes sociais, destacando o papel das ideias no processo de representação.

Assim é que a representação, nos dias atuais, não pode ser reduzida nem a um contrato de delegação firmado por meio de eleições, nem à nomeação de legisladores para substituírem um soberano ausente, uma vez que está dinamicamente ligada à sociedade e requer, portanto, constante renovação. A História moderna parece sugerir, pois, que a origem da democratização está no processo representativo, reforçando o papel ideológico e dos movimentos políticos na consolidação da democracia.

Nadia Urbinati ${ }^{173}$, munida dos estudos acima elencados, enfoca a representação como o espelho da constante tensão entre sociedade e Estado. É espelho que reflete não meras opiniões e ideias, mas opiniões e ideias acerca das visões que os cidadãos têm sobre a relação entre sociedade e Estado. De cerca de duzentos anos de história do governo representativo - do parlamentarismo liberal do início até sua crise, seguido de sua transformação democrática, depois da segunda guerra mundial - a autora extrai três teorias da representação: a jurídica, a institucional, e a política. Cada uma delas oferece uma abordagem específica da relação entre Estado e sociedade.

A teoria jurídica concebe a representação como um com contrato de comissão, consoante as linhas de uma lógica individualista e não-política, com base na suposição de que os eleitores julgam as qualidades pessoais dos candidatos, e não suas ideias políticas ou projetos. A representação, nessa esteira, não seria nem um processo, nem uma matéria política, não havendo espaço para demanda por representação ou representação justa.

O modelo jurídico, ademais, reúne as questões sobre poder estatal e legitimidade na lógica presença/ausência (do soberano), o que abre as portas para uma justificação

\footnotetext{
${ }^{171}$ MANIN, Bernard. The Principles of Representative Government, Cambridge: Cambridge University Press, 1997.

${ }^{172}$ KISHLANSKY, Mark A. Parliamentary Selection: Social and Political Choice in Early Modern England, Cambridge: Cambridge University Press, 1986.

${ }^{173}$ URBINATI, 2008.
} 
funcionalista dos direitos políticos, da cidadania e dos processos de tomada de decisão. Tornou-se, assim, o alicerce do governo representativo liberal, pois é baseada em um dualismo bem definido entre Estado e sociedade - a representação é centrada rigorosamente no Estado, cuja relação com a sociedade é deixada ao juízo do representante, e a participação popular é restrita a um mínimo procedimental.

Dita perspectiva estabelece dois cenários possíveis. De um lado, nos moldes do que pregava Rousseau, a representação não poderia ser admitida, pois implicaria a transferência do poder de autorização do uso da forca da comunidade como um todo para sua parte. De outro, como defendia Sièyes, a representação simbolizaria uma estratégia de edificação de instituições, contanto que fosse da incumbência dos súditos a tarefa de selecionar os legisladores.

Carl Schmitt ${ }^{174}$ é exemplo emblemático de autor que, durante a crise do parlamentarismo do começo do século vinte, recuperou a função construtivista da representação defendida por Hobbes e Sièyes, utilizando-a para reconstruir a unidade orgânica do povo acima do pluralismo dos interesses sociais, por meio da personificação do soberano. O objetivo em vista era a obtenção de um Estado unificado mais solidamente do que aquele em que prevalecia compromisso parlamentar entre interesses plurais.

A teoria institucional da representação, assim como a jurídica, assume que o Estado deve transcender a sociedade de forma a assegurar o Estado de Direito, sendo essencial que as pessoas encubram suas identidades sociais e concretas e tornem os mandatários agentes imparciais de decisão. Evidencia-se nessa teoria também a suposição de que a identidade jurídica do eleitor/autorizador é vazia, abstrata e anônima, e sua função seria apenas nomear políticos profissionais que tomem decisões às quais os eleitores submetem-se voluntariamente. Nos termos de Carré de Malberg ${ }^{175}$, não seria um sistema de representação do povo e da vontade da nação, mas um sistema de organização do povo e da vontade da nação.

A terceira teoria - a da representação política - apresenta modelo eminentemente diferenciado. A representação é concebida dinamicamente, e não mais estaticamente, além de não ter mais seu foco em fazer uma entidade preexistente (como a unidade da nação) visível. Ela não pertence apenas aos agentes governamentais, mas designa um processo político estruturado com base na circularidade entre as instituições e a sociedade, não

\footnotetext{
${ }^{174}$ SCHMITT, Carl. A crise da democracia parlamentar. São Paulo: Scritta, 1996.

${ }^{175}$ MALBERG, R. Carré de. Teoria General del Estado. Tradução: José Lión Depetre. Ciudad de Mexico: Fondo de Cultura Económica, 2001.
} 
estando confinada à deliberação e decisão na assembleia. A unidade necessária não será compreendida como corolário lógico da unidade daquele que representa (como pretendia Hobbes), mas deverá ser criada e recriada por processo político dinâmico.

Segundo a teoria política da representação, a generalidade da lei e os critérios de imparcialidade derivados da cidadania não sacrificam automaticamente a visibilidade política do "homem”, uma vez que às trocas ideológicas entre a sociedade política e a sociedade civil é conferido caráter essencial. Nas palavras de Urbinati:

\begin{abstract}
A teoria política da representação argumenta que, em um governo que deriva sua legitimidade de eleições livres e regulares, a ativação de uma corrente argumentativa entre a sociedade política e a civil é essencial e constitutiva, não apenas inevitável ${ }^{176}$.
\end{abstract}

O centro de gravidade da sociedade democrática segue sendo o povo, no papel de cidadãos, e não meros eleitores, o que faz do processo de autorização algo mais importante que o ato de autorização. Confira-se, por oportuno, esclarecimento de Hannah Pitkin: “A representação aqui significa agir no interesse dos representados, de uma maneira responsiva a eles”"177.

É essa terceira concepção de representação de que se utilizam alguns autores para construírem a base de suas teorias democráticas, fundadas na modalidade representativa, ainda que ofereçam, cada qual a sua maneira, releituras diversas de sua concretização.

Muito embora Ronald Dworkin já tenha apresentado sua teoria acerca da democracia em obras previamente dedicadas ao tema ${ }^{178}$, em sua mais recente obra, intitulada Justice for Hedgehogs ${ }^{179}$, o jurista retoma o repúdio à concepção majoritária de democracia, de natureza cruamente procedimental (funda-se tão somente na regra da maioria), para defender o que denomina uma concepção “associativa” (partnership conception), que vincula a democracia a restrições substantivas relacionadas à

\footnotetext{
${ }^{176}$ URBINATI, Nadia, O que torna a representação democrática, paper apresentado no Encontro Anual da American Political Science Association (Apsa), tradução de Mauro Soares. Washington (EUA), setembro de 2005, p. 202.

177 PITKIN, Hannah Fenichel. The Concept of Representation. Berkeley: University of California Press, 1967, p. 209.

${ }^{178}$ Ele aborda a questão mais a fundo nas seguintes obras: Law’s empire (Cambridge, Massachusetts: The Belknap Press of Harvard University Press, 1986) e Is Democracy possible here? Principles for a new political debate (New Jersey: Princeton University Press, 2006).

${ }^{179}$ DWORKIN, Ronald. Justice for Hedgehogs. Cambridge, Massachusetts: The Belknap Press of Harvard University Press, 2011.
} 
legitimidade. E como a legitimidade é compreendida em termos de graus, assim também ocorre com a democracia associativa de Dworkin.

A legitimidade, na teoria de Dworkin, requer uma distribuição de poder político que reflita igual preocupação e respeito da comunidade por cada cidadão. Trata-se de reflexo de seus dois subprincípios da dignidade, que determinam, respectivamente, a) a aceitação do valor objetivo da vida de todo e cada indivíduo (o princípio do valor intrínseco) e b) a autodeterminação de cada indivíduo de acordo com os valores éticos elencados por ele próprio (princípio da responsabilidade pessoal).

É nesse cenário teórico que Dworkin arquiteta construção relativa ao governo representativo e sua posição dentro da teorização democrática. Ele conclui que as teorias democráticas de concepção majoritária encaram o governo representativo como um mal necessário, procurando reduzir a desigualdade do impacto que os representantes políticos possuem em relação a um cidadão comum por meio de medidas de ameaça e incentivo liberdade de imprensa e eleições frequentes - e objetivando que os eleitores se atenham o máximo possível à vontade da maioria. A defesa do governo representativo realizada pela concepção majoritária seria, portanto, fraca - não resiste, por exemplo, ao argumento de que questões principiológicas de grande envergadura devem ser submetidas a referendos e não ao processo político ordinário.

A concepção associativa, para Dworkin, oferece uma justificativa mais satisfatória para o governo representativo. O fato de serem os cidadãos em geral, e não grupos específicos deles (como minorias), a possuírem seu impacto político diminuído na transferência de poder aos representantes eleitos afasta o automático déficit democrático. Dworkin admite que indivíduos e políticos ponderados irão divergir quanto às melhores estruturas para aumentar a chance de que a comunidade demonstre igual preocupação e respeito por todos, mas ressalta que é esse, no entanto, o teste da concepção associativa, e não a matemática crua da regra da maioria.

O italiano Gustavo Zagrebelsky, em sua obra intitulada “A Crucificação e a Democracia” ${ }^{180}$, preconiza distinção entre a democracia crítica e a acrítica (ou radical), esta última responsável pelo repúdio a todo e qualquer instrumento de representação a serviço do governo democrático. Nessa perspectiva acrítica, as autoridades, sem distinção,

180 ZAGREBELSKY, Gustavo. A crucificação e a democracia, Tradução Mônica de Sanctis Viana. São Paulo: Saraiva, 2011. 
são repudiadas por traduzirem formas de supressão da soberania popular, em caminho perigoso que pode descambar em regimes autoritários ${ }^{181}$.

Daí a necessidade de se recusar o que ele denomina "ilusão” de uma democracia baseada diretamente na voz do povo. As instituições clássicas do povo capacitado para a ação, segundo Zagrebelsky, são os partidos políticos. Apesar de reconhecer que esses últimos atravessam período de crise quiçá insuperável, a democracia crítica necessitaria dos partidos ou em sua forma conhecida ou em outras formas de integração social para fins políticos, como, por exemplo, novas instituições de comunicação ativa e circular entre os cidadãos por meio de técnicas informáticas.

Tanto Dworkin quanto Zagrebelsky, em suas obras citadas acima, não chegam a defender modelo propriamente representativo de democracia, mas tampouco chegam afastá-lo em absoluto. Admitem, por certo, sua insuficiência teórica, mas tomam como base aspectos mínimos da estrutura representativa, a partir dos quais desenvolvem especificações conceituais próprias da teoria de cada qual. Para uns, poderiam ser classificados como defensores de espécie de democracia deliberativa (Dworkin e sua leitura moral da constituição pressupõem um exercício deliberativo); para outros, seriam partidários de uma releitura da própria democracia representativa.

\subsection{Ataques à ideia de representação}

2.4.1 O Parlamento não é a encarnação essencial da democracia, mas a conversão de uma instituição que historicamente exerceu outros propósitos.

Voltando às linhas centrais de argumentação traçadas por Hübner Mendes, o primeiro grupo de críticas à representação eleitoral vem assim resumido: “O Parlamento não é a encarnação essencial da democracia, mas a conversão de uma instituição que historicamente exerceu outros propósitos”182.

\footnotetext{
${ }^{181}$ Nos termos do autor: "Questiona-se, assim, a complexa articulação dos poderes públicos, construída sobre a experiência secular do constitucionalismo e baseada em instâncias independentes de garantia, equilíbrio e compensação. Tais instâncias podem renunciar à sua independência secundando o movimento que se transferiu para a decisão popular e dessa forma renegando a si mesmas, ou perdendo o seu direito constitucional à estabilidade, para estarem sempre em sintonia com a vontade popular" (ZAGREBELSKY, 2011, p. 147).

${ }^{182}$ MENDES, 2011, p. 83.
} 
Construiu-se por toda a História da política ocidental a ideia de que a democracia traduz-se para a realidade prática das instituições por meio do governo representativo. As eleições chamam à participação e ao posicionamento o cidadão comum, o que o insere como membro atuante e com voz naquela comunidade política: o ato democrático por excelência.

Como visto acima, autores da ciência política contextualizaram historicamente a representação, estudo pelo qual concluíram estar ela fundada em origem oligárquica e antidemocrática - nas palavras de Manin, consistia em um sistema de contenção arquitetado por “aristocratas ingleses, fazendeiros americanos e advogados franceses” 183 .

E se agora a ampliação do direito de voto conferiu feições mais democráticas ao processo eleitoral, o resultado foi uma ampliação da participação, mas não o seu aprofundamento. Para Urbinati, de "uma instituição de duas faces, as eleições conferem à representação uma faceta democrática e à democracia uma nuance aristocrática” ${ }^{184}$. Ao povo não seria permitido governar, mas tão-somente selecionar governantes e julgar seu desempenho periodicamente.

2.4.2 A dinâmica representativo-eleitoral incentiva um comportamento legislativo que barateia direitos fundamentais.

A segunda série de críticas é assim enunciada: “A dinâmica representativo-eleitoral incentiva um comportamento legislativo que barateia direitos fundamentais" 185 .

A forma como as legislaturas são internamente organizadas, aduz-se, faz com que direitos sejam apenas um dos muitos componentes a figurarem na balança das votações legislativas, de modo que perderiam seu lugar de preocupação primária ${ }^{186}$. Virariam moeda de troca em negociações e barganhas, e não trunfos, que é o papel que deveriam exercer em um regime político que leva direitos a sério.

E o quadro pode piorar, considerando-se que direitos podem nem sequer fazer parte da agenda remota do Parlamento. A motivação dos representantes, geralmente, estaria em satisfazer interesses imediatos de eleitores, a despeito da posição em que isso os colocaria

\footnotetext{
183 MANIN, 1997, p. 234.

${ }^{184}$ URBINATI, 2008, p. 3.

${ }^{185}$ MENDES, 2011, p. 84

${ }^{186}$ PICKERILL J. Mitchell. Constitutional Deliberation in Congress: the Impact of Judicial Review in a Separated System. Duke University Press, 2004.
} 
em face de direitos, tudo para aumentar as chances de reeleição e manutenção do poder, pelo poder em $\mathrm{si}^{187}$.

Ademais,

\begin{abstract}
Parlamentos são, ainda, foros destinados à retórica, à teatralização e à opinião forte, nada que se compare a um foro deliberativo sereno, em que pessoas argumentam sinceramente para tentar convencer seus pares, respeitam o desacordo e estão abertas a serem conhecidas. Ao contrário, discursos se dirigem à audiência externa, a marcar posições que resultem em votos nas eleições ${ }^{188}$.
\end{abstract}

2.4.3 A representação eleitoral não é o único tipo possível de representação. Trata-se de uma representação puramente agregativa, atomística, que pensa a política como mercado.

Eis o ponto de reflexão: “A representação eleitoral não é o único tipo possível de representação. Trata-se de uma representação puramente agregativa, atomística, que pensa a política como mercado"189.

Aqui o raciocínio estrutura-se em torno da ideia de que a escolha eleitoral de representantes não esgota a representação, mas é apenas uma de suas modalidades. Wil Waluchow vai mais além para constatar que o ato de escolher representantes não é necessário para o ato de representar. Haveria diversas situações em que representantes não teriam sido escolhidos pelos representados, mas ainda assim não deixariam de representálos legitimamente, como no caso dos juízes ${ }^{190}$.

A condição de autogoverno não se perde apenas porque juízes não-eleitos proferem a última palavra - pode ser decisão que a sociedade considera como sua, representativa de seus anseios e realizadora de direitos. Se o legislador, ao prevalecer sobre a Corte, desrespeita direitos, a percepção de autogoverno coletivo aí sim irá diminuir. O fenômeno do autogoverno mostra-se, pois, mais complexo e rico do que a ação de escolher, de tempos em tempos, representantes por meio do voto.

Para Frank Michelman ${ }^{191}$, desde que surgiu a necessidade de separação entre a figura do governante e a do governado, as instituições democráticas passaram a concentrar

\footnotetext{
${ }^{187}$ Cf. MAYHEM, David. Congress: The Electoral Connection. New Haven: Yale University Press, 1975.

${ }^{188}$ MENDES, 2011, pp. 84-85.

${ }^{189}$ MENDES, 2011, p. 85.

${ }^{190}$ WALUCHOW, Wil. A Common Law theory of Judicial Review: The Living Tree. Cambridge: Cambridge University Press, 2007.

${ }^{191}$ MICHELMAN, Frank. Traces of Self-Government. Harvard Law Review, v. 100, 1986.
} 
meros rastros de autogoverno. As determinações que partem de dirigentes não são manifestações de autogoverno, razão pela qual sua reforma por juízes não necessariamente subtrai nada da liberdade de cada indivíduo, muito embora a manifestação de juízes, tampouco, possa ser considerada forma de autogoverno. Suas decisões, contudo, podem aumentar essa liberdade individual, assim como restringi-la indevidamente. Nesse sentido, a ficção do governo representativo não é melhor que a ficção das cortes. Michelman emprega o termo "fetichismo" para descrever a defesa indiscriminada de uma ou outra como autogoverno.

Gargarella ressalta outra medida de ficção presente na ideia de que eleições constituem forma viável de representação da pluralidade de interesses e situações existentes na sociedade atual. Seria implausível acreditar que o Parlamento pudesse refletir tamanha diversidade, levando-se em conta que nem um único partido ou mesmo um único candidato compartilha das preferências de todos os seus eleitores ${ }^{192}$.

\subsubsection{Restrições ao Parlamento eleito não resgatam argumentos da tradição} antidemocrática. Simplesmente apontam problemas que os incentivos institucionais geram no comportamento do legislador.

Buscando fugir de alcunhas elitistas, o argumento que se propugna exibe a seguinte visão: "Restrições ao Parlamento eleito não resgatam argumentos da tradição antidemocrática. Simplesmente apontam problemas que os incentivos institucionais geram no comportamento do legislador" ${ }^{\prime 93}$.

Essa linha de críticas sustenta que admitir a eventual prevalência de decisão judicial sobre a decisão legislativa não evoca as clássicas inclinações antidemocráticas, que difundem o preconceito contra a massa, a ideia de despreparo do cidadão comum, e a necessidade de guardiões, entre outras crenças. Cuida-se apenas de considerações acerca das instituições - dizer que juízes estão em um ambiente institucional mais adequado para certo tipo de decisão não implica a assunção de que seriam melhores, ou que possuiriam capacidade argumentativa superior.

192 GARGARELLA, Roberto. Full Representation, Deliberation and Impartiality. In: ELSTER, Jon (Ed.). Deliberative Democracy. Cambridge: Cambridge University Press, 1998.

${ }^{193}$ MENDES, 2011, p. 86. 
Para Whittington ${ }^{194}$, o esforço de Waldron em pintar um quadro favorável das legislaturas leva sua análise a desconsiderar aspectos básicos da política institucionalizada. E levar as instituições a sério seria importante na avaliação das justificativas para a revisão judicial, e ainda mais importante ainda na análise comparativa de instituições que Waldron realiza em sua pesquisa. Ele, entretanto, trata Parlamentos e Cortes como instituições equivalentes, diferindo apenas quanto aos agentes decisórios e ao número de cabeças a serem contadas. Fica prejudicada, na análise, a percepção de que as vantagens do Parlamento podem ser parciais e relativas.

Transcreve-se abaixo trecho de Hübner Mendes, por oportuno:

\begin{abstract}
É surpreendente, por exemplo, como a complexidade congressual passa ao largo do argumento de Waldron contra a revisão judicial. Para ele, o congresso é um conjunto de representantes que decide por maioria. Numa escala menor, corresponde ao povo tomando suas decisões em conjunto pelo procedimento mais igualitário possível. Sua teoria normativa é tão abstrata e rasa quanto a isso. O resto - comitês, hierarquia partidária, poder de agenda etc. - parece ser mero detalhe. Seria produto de uma visão cínica sobre a pessoa do representante eleito. Não percebe que legisladores, mesmo bem intencionados, estão imersos numa rede de constrangimentos institucionais incontornáveis. Os problemas da representação eleitoral e da regra da maioria não desaparecem quando elegemos legisladores virtuosos ${ }^{195}$.
\end{abstract}

\title{
2.5 Ataques à regra da maioria
}

2.5.1 A regra da maioria é insensível à intensidade de preferências.

O primeiro grupo de críticas à regra da maioria vem assim apresentado: “A regra da maioria é insensível à intensidade de preferências” ${ }^{196}$.

Argumenta-se que o procedimento majoritário consistente em votos com peso idêntico não consegue captar a relevância da matéria votada para cada indivíduo. Uma parte terá o tema como prioridade em sua agenda (geralmente minorias engajadas). Outra parte ficará em dúvida, não concordando nem discordando, mesmo acreditando que possa haver uma resposta certa ou ao menos mais próxima da verdade. Não estando, contudo, convencida, ela não se sente confortável para integrar a maioria ou a minoria. Há ainda uma terceira parte, que estará indiferente e não se importará com a aprovação ou

\footnotetext{
${ }^{194}$ WHITTINGTON, Keith. Review Essay: In Defense of Legislatures. Political Theory, v. 28, n. 5, 2000.

${ }^{195}$ MENDES, 2011, p. 86.

${ }^{196}$ MENDES, 2011, p. 87
} 
reprovação da medida. Pela regra da igualdade formal, as três partes entram com igual peso na contabilização dos votos, prejudicando assim os primeiros, os verdadeiros interessados.

Como argumenta Dworkin, a regra da maioria promoveria, no máximo, a igualdade de impacto, mas não a igualdade de consideração e respeito, realizando uma noção insuficiente de igualdade ${ }^{197}$.

2.5.2 A regra da maioria não tem a racionalidade que parece. Seu resultado é arbitrário.

No argumento de que “a regra da maioria não tem a racionalidade que parece. Seu resultado é arbitrário" ${ }^{198}$, Kenneth Arrow é quem se destaca por meio da demonstração de que a vontade da maioria nem sempre é obtida com uma votação por maioria. E isso se dá em razão do que ele chama de "ciclo de votação" - quem tem o poder de controlar a ordem de votação consegue, muitas vezes, determinar a decisão final. Assim, o procedimento majoritário provavelmente faria prevalecer a vontade de uma minoria estrategicamente bem posicionada $^{199}$.

2.5.3 O mundo não é bipartido entre minoria e maioria. Preferências políticas, ademais, não são estáticas.

A última espécie de argumentação contrária à regra da maioria vem assim exposta: “O mundo não é bipartido entre minoria e maioria. Preferências políticas, ademais, não são estáticas”, 200 .

Um olhar mais atento à “dificuldade contramajoritária” evidencia que a construção de ideias em sua base divide a sociedade em dois grupos: a maioria e a minoria. A maioria estaria nas legislaturas e a minoria nas cortes. Como vem sendo dito já muitas vezes acima, pensar em termos de maioria versus minoria é ignorar complexidades inúmeras e diversas.

Barry Friedman ${ }^{201}$ adverte que não se sustenta a premissa de que do Parlamento se originam decisões da maioria representada por uma agregação simples de posições prontas,

\footnotetext{
197 DWORKIN, Ronald. Freedom's Law: a Moral Reading of the American Constitution. Cambridge: Harvard University Press, 1996.

${ }^{198}$ MENDES, 2011, p. 87.

${ }^{199}$ SHAPIRO, Ian. The State of Democratic Theory. Princeton: Princeton University Press, 2006.

${ }^{200}$ MENDES, 2011, p. 87.
} 
inflexíveis. Preferências humanas são maleáveis e podem ser transformadas pelo debate. Logo, não são preferências fixas e exógenas, mas mutáveis e endógenas, continuamente redesenhadas pela passagem do tempo. Daí a dificuldade do processo político de refletir preferências individuais e sociais em constante transformação.

Hübner Mendes traz, ainda, a questão da dinâmica do jogo político e da necessidade de atitudes concessórias, a despeito da integridade dos agentes políticos:

A sociedade não está dividida entre duas alternativas estáticas. A votação final de um projeto de lei, por exemplo, não pode ser vista como uma divisão entre aqueles que a aprovam e os que a rejeitam, pois isso ignoraria todo o processo anterior de composição de diferentes graus de interesse. Legisladores íntegros poderão ter escalas de preferências morais sinceras (não meramente escalas de interesses egoísticos), mas, de qualquer modo, terão que compor ${ }^{202}$.

A vontade majoritária forma, a toda evidência, um bloco heterogêneo de interesses, os quais devem por vezes inclinar-se mais para um ou outro lado em nome de concessões que possibilitam às engrenagens rodarem. Acrescente-se o fator tempo nessa equação, e então não há como se falar em estabilidade e rigidez. A correlação perfeita entre as opiniões dos representados e de seus representantes, quando possível, mostra-se efêmera e volátil. O que estão as Cortes a revogar por meio da revisão judicial, conclui-se, não constitui a perfeita e sagrada vontade da maioria.

Compreendidas, pois, a maior e mais relevante parte das linhas de argumentação que procuram atribuir a autoridade superior na satisfação de direitos a uma instituição ou outra, no contexto do sistema de governo, passa-se, no próximo capítulo, às possibilidades advindas do diálogo entre Cortes e Parlamento. Cuida-se de uma nova forma de encarar tanto a jurisdição constitucional quanto a atividade legislativa - nenhuma é perfeita e ideal, mas são as duas cheias de potencial benéfico, otimizado à medida que se identifiquem e se trabalhem os impactos recíprocos.

\footnotetext{
${ }^{201}$ FRIEDMAN, 1993.
}

${ }^{202}$ MENDES, 2011, p. 88. 


\section{- CAPÍTULO III - O DIÁLOGO INSTITUCIONAL}

\section{Influências institucionais à atuação da Corte}

À luz de análises enfocadas no modelo de interação institucional, a teoria constitucional se propõe a lançar olhares renovados sobre a dinâmica de Poderes na composição institucional do Estado. Nessa perspectiva, o comportamento individual de agentes políticos segue sendo relevante objeto de consideração, mas ganha espaço tão ou mais importante a ponderação das influências recíprocas exercidas entre Poderes estatais, em especial entre Judiciário e Legislativo. Pesquisas empíricas imbuídas desse propósito interacional vêm dando conta de que as principais Supremas Cortes de democracias constitucionais estão sintonizadas com a opinião pública na maior parte das questões politicamente relevantes $^{203}$. Assim, fica evidente que não apenas a ideologia ou o Direito constrangem o comportamento judicial, mas também a atuação estratégica dos Poderes, guiada por diversos fatores institucionais e políticos.

Na opinião de Barry Friedman, a tentativa frustrada de Roosevelt de aprovar seu court packing plan, já relatada no capítulo 1, exerceu profundo impacto na dinâmica das relações entre a Suprema Corte e os poderes políticos quanto à definição de direitos. Teria sido estabelecido, desde o marcante episódio, um acordo tácito entre os Poderes - ao Judiciário garantiu-se o exercício de um poder político relevante, com a condição essencial de que não se afaste demais da opinião pública, especialmente quando estejam em jogo

\footnotetext{
${ }^{203}$ FRIEDMAN, Barry. The will of the people: how public opinion has influenced the Supreme Court and shaped the meaning of the Constitution. New York: Farrar, Strauss and Giroux, 2009.
} 
questões politicamente sensíveis ${ }^{204}$. É conclusão de natureza tipicamente neoinstitucional, reavivando o debate constitucional.

\subsection{Os momentos iniciais de uma nova ordem constitucional}

Bastante intuitiva é a percepção de que as Cortes, cientes da possibilidade de ataques institucionais decorrentes de decisões desprovidas de sustentação política, tendem a evitar o emprego de seu poder revisional com vistas a sua autopreservação, guiando-se inclusive por meio de reação antecipada, em que altera sua preferência original para adequar-se à posição aceitável pelos poderes políticos ${ }^{205}$. Seria igualmente intuitivo esperar que, após o advento de uma nova Constituição, a Suprema Corte proferisse mais decisões de invalidade constitucional, uma vez que neste momento persistiriam normas e práticas erigidas sob o regime constitucional anterior, incompatíveis, portanto, com a nova ordem constitucional.

Não foi, contudo, o que Tom Ginsburg constatou após análise comparativa da jurisprudência de Supremas Cortes em novas democracias. O padrão verificado foi o oposto, com Cortes mais cautelosas na afirmação de seu poder nos momentos iniciais do novo regime, apresentando a partir dali curva ascendente de ativismo ${ }^{206}$. Ginsburg menciona, contudo, a exceção do caso Russo logo após o fim da União Soviética, quando sua jovem Corte Constitucional decidiu casos difíceis ligados à separação de poderes e desafiando agentes políticos de envergadura no cenário nacional. Invalidou decreto presidencial que havia unificado as forças de segurança dentro de um só Ministério, ao argumento de que tal medida representava usurpação do poder normativo do Parlamento. Ao apreciar outro decreto do Presidente Boris Yeltsin dispersando o Partido Comunista e confiscando seus bens, adotou decisão intermediária para validá-lo face ao diretório nacional do Partido, mas invalidá-lo em relação aos diretórios estaduais. Acabou por desagradar a todos.

A crise política entre Presidente e Parlamento se aprofundava na Rússia, e a Corte Constitucional se envolvia publicamente nas negociações político-partidárias, afastando qualquer tentativa de difusão da imagem de neutralidade política. A crise culminou na

\footnotetext{
${ }^{204}$ FRIEDMAN, 2009.

${ }^{205}$ WHITTINGTON, 2003.

206 GINSBURG, Tom. Judicial Review in New Democracies - Constitutional Courts in Asian Cases. Cambridge University Press, 2003.
} 
publicação de decreto garantindo a Yeltsin poderes de emergência em março de 1993. O então presidente da Corte Constitucional, Valery Zorkin, deu entrevistas denunciando em rede nacional a ilegalidade do ato normativo. Em alguns meses, o Parlamento foi dissolvido e a Corte Constitucional teve seu funcionamento suspenso, só voltando a atuar dois anos depois, com poderes reduzidos e sem nunca mais voltar a adotar posturas ativistas em questões políticas de relevância ${ }^{207}$.

O exemplo russo é um que foge ao padrão constatado por Ginsburg, para quem a Suprema Corte precisa construir sua imagem de neutralidade política nos primeiros anos da nova ordem constitucional, de modo a desenvolver blindagem contra retaliações e ataques institucionais. Atém-se então a uma aplicação mais formal do Direito, evitando aplicar princípios abstratos a questões políticas de relevo - avança devagar com o intuito de consolidar e expandir seu poder ${ }^{208}$. O exemplo russo, nessa medida, se foge à regra identificada por Ginsburg de contenção ativista da Suprema Corte em seus primórdios, acaba por confirmar na prática a reação que justificaria a necessidade de autoconstrição: Cortes que interferem demais no jogo político de um regime de governo iniciante têm seus poderes tolhidos como forma de reprimenda. É, portanto, exceção que só confirma a regra.

Rodrigo Brandão, lançando mão de valiosíssima investigação empírica, afirma que a evolução da jurisprudência do STF pós-1988 demonstra a tendência de progressivo crescimento do ativismo judicial à medida que o regime constitucional brasileiro vai envelhecendo ${ }^{209}$. Com efeito, logo após a promulgação da Constituição Federal de 1988, a postura adotada foi a de autoconstrição, que o autor ilustra em três casos paradigmáticos.

O primeiro estaria na consolidação do entendimento de que a incompatibilidade de lei anterior à Constituição com seu novo teor encerra hipótese de revogação, e não de inconstitucionalidade superveniente, afastando assim o cabimento de Ação Direta de Inconstitucionalidade ${ }^{210}$. O segundo caso foi o da ADI 223-6/DF ${ }^{211}$, em que se questionava a constitucionalidade da Medida Provisória 173/1990, que vedou ao Judiciário o poder de conceder liminares decorrentes de anteriores medidas provisórias que haviam promovido a retenção de recursos depositados em bancos no cenário do Plano Collor. Alegando que a generalidade, a diversidade e a imprecisão dos limites da vedação de liminar impediam a verificação de sua razoabilidade em tese, o STF absteve-se de suspender a eficácia da

\footnotetext{
${ }^{207}$ GINSBURG, 2003.

${ }^{208}$ GINSBURG, 2003.

${ }^{209}$ BRANDÃO, 2012.

${ }^{210}$ Precedente firmado na ADI 438, STF, Pleno, RDA, 187:152, 1992.

${ }^{211}$ STF, Pleno, Rel. Min. Sepúlveda Pertence, DJ 29/06/1990, julgamento 05/04/1990.
} 
medida, indeferindo a liminar, mas prevendo que cada caso concreto tivesse sua constitucionalidade examinada judicialmente.

O terceiro e último caso mencionado por Brandão seria o do Programa Nacional de Desestatização do governo de Fernando Henrique Cardoso, em que o STF não invalidou nenhum leilão de privatização da antiga empresa estatal, nem julgou procedente nenhumas das 39 Ações Diretas de Constitucionalidade referentes ao tema ${ }^{212}$.

\subsection{A teoria da escolha racional}

Com o centro da análise passando agora ao processo decisório, destacam-se as denominadas "teorias do equilíbrio" na explicação dos limites políticos e institucionais a influenciarem as Supremas Cortes. Dentre essas teorias encontra-se o modelo da rational choice, adotando enfoque estratégico na forma de analisar as decisões das Cortes em relação às preferências dos demais Poderes. Nesse contexto encaixa-se o trabalho de William Eskridge Jr., que concluiu que o Judiciário, ao invés de simplesmente aplicar suas preferências - ideológicas ou jurídicas -, as submete antes a um “jogo político sequencial”213, em tradução lançada por Rodrigo Brandão ${ }^{214}$.

Sua teoria atribui uma dimensão dinâmica à interpretação do direito, como resultado da separação dos poderes e dos mecanismos de freios e contrapesos correspondentes. Como regra, tem-se que a aprovação de uma lei demanda a conjugação de preferências de uma maioria parlamentar e do Presidente da República, que pode exercer seu poder de veto. O poder que o controle de constitucionalidade confere ao Judiciário também torna relevante sua preferência - o resultado final do processo, portanto, será fruto da interação das preferências dos Poderes.

Antes que o jogo comece, cada jogador possui uma preferência crua, original, que é o resultado prático que realmente desejam. Diante do risco de que essas preferências sejam refutadas pelas preferências dos demais jogadores, o objetivo do jogo é atuar estrategicamente para que da interação resulte o provimento mais próximo possível da preferência inicial, que deverá sofrer alteração para que algum tipo de vitória, ainda que

\footnotetext{
${ }^{212}$ BRANDÃO, 2012.

${ }^{213}$ ESKRIDGE Jr. e WILLIAM N. Overriding Supreme Court Statutory Decisions. Yale Law Journal, v. 101, n. 2, 1991.

${ }^{214}$ BRANDÃO, 2012, p. 253.
} 
parcial, possa ser obtida. O resultado naturalístico dessa interação é que se encontre um ponto de indiferença, onde as preferências dos jogadores estarão em equilíbrio.

Hansford e Damore exemplificam a dinâmica em mente: se a preferência da Corte está em um ponto intermediário entre as preferências do legislador e do Presidente, então a tendência da Corte é aplicar sua preferência crua sem medo de reação política, já que para os outros jogadores a preferência da Corte é mais aceitável do que a do outro adversário. Todavia, se a preferência da Corte estiver em uma das extremidades da linha, a do legislador em ponto intermediário, e a do Presidente no extremo oposto, então a tendência é adotar postura de autorestrição judicial, pois uma postura ativista poderia levar à união do Legislativo e do Executivo para superar a decisão ${ }^{215}$.

Eskridge utiliza o exemplo prático da Era Lochner como reforço empírico de sua tese. Em um novo contexto sócio-político, em que a liberdade privada enfrentava mais restrições em nome da busca pelo Estado do bem-estar social encabeçada pelo Presidente Franklin Roosevelt e também por um Congresso majoritariamente democrata, as atuações ativistas da Suprema Corte americana para preservar o liberalismo econômico foram encaradas como suicidas, e logo se observou o início da mudança de posicionamento dessa mesma Corte, com a mesma composição de antes ${ }^{216}$. O autor também ressalta que o modelo é corroborado pelo fato de que as decisões mais duradouras da Suprema Corte americana foram proferidas em temas altamente controvertidos, impossibilitando aos outros atores políticos (ou jogadores) a união de forças para a superação da decisão judicial por meio dos mecanismos políticos à disposição ${ }^{217}$.

Hansford e Damore, por outro lado, alertam para o aspecto de que, apesar de trazer interessantes insights para a análise da relação interinstitucional, a teoria da escolha racional superestima o conhecimento pelos jogadores das preferências de seus adversários, bem como desconsidera a influência de fatores exógenos à preferência crua dos atores políticos, como a atuação de grupos de interesse articulados e interferência da opinião pública $^{218}$.

A propósito, quanto à interferência de movimentos sociais na interpretação constitucional, Post e Siegel defendem que quando a Suprema Corte se afasta em grande medida da opinião pública, o povo encontra meios de comunicar sua oposição e ainda

\footnotetext{
${ }^{215}$ HANSFORD, Thomas G. e DAMORE, David F. Congressional preferences, perceptions of threat, and Supreme Court decision making. American politics quarterly, v. 28, n. 4, 2000.

${ }^{216}$ ESKRIDGE, 1991.

217 ESKRIDGE, 1991.

${ }^{218}$ HANSFORD e DAMORE, 2000.
} 
reverter a decisão judicial dissonante. Eles citam como exemplo o entendimento, que perdurou na Suprema Corte americana até o fim da década de 1970, de que distinções baseadas em gênero não violavam a cláusula constitucional de igualdade perante a lei, razão por que não haveria que se falar em necessidade de controle de constitucionalidade. A organização dos movimentos feministas mobilizou grande parte da opinião pública e o senso comum mudou, de modo que os juízes da Suprema Corte não tiveram outra opção senão rever sua jurisprudência e julgar tais distinções inconstitucionais, porquanto contrárias à igualdade ${ }^{219}$.

Rodrigo Brandão conclui que “os mecanismos de reação a decisões da Suprema Corte atuam como limites institucionais à sua jurisprudência, que a influenciam tanto

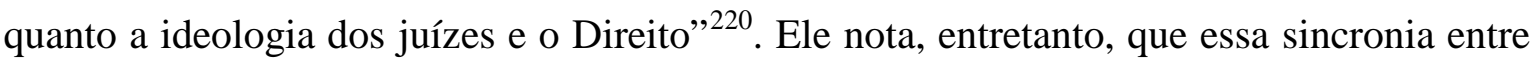
a opinião pública e a jurisprudência da Suprema Corte tem eficácia variante de acordo com a seara em que se encontra o tema controvertido. Em casos de alta relevância política, a influência da opinião pública seria mais significativa, ao passo que questões de menor repercussão entre grupos políticos e econômicos influentes, é mais comum que a Suprema Corte adote papel menos atrelado à accountability, pela menor veiculação de sua decisão. Nesses casos específicos, argumenta Brandão, a chance é grande de que o Judiciário venha realmente a fixar a solução final por excelência, proferindo, pois, a última palavra.

A constatação, assim, de que o potencial de controle de constitucionalidade é mais reduzido precisamente quando há forte oposição de grupos políticos e econômicos justamente quando mais necessária se mostra a proteção de direitos de minorias contra a influência dos poderosos - não implicaria o próprio reconhecimento da falência do constitucionalismo?

Brandão responde que não. Reconhece que as teorias empíricas já lograram provar que o Judiciário não consegue desempenhar o messiânico dever de Guardião da Constituição, mas ainda assim atribui a ele função politicamente relevante. Isso porque o próprio reconhecimento de quão influente pode ser a opinião pública em seus julgamentos acaba por estimular a concepção de teorias prescritivas incitando o Judiciário a efetivar sua “cota de decisões contramajoritárias”, protegendo, aqui e ali, minorias estigmatizadas.

${ }^{219}$ POST, Robert e SIEGEL, Reva. Democratic constitutionalism and backlash. Harvard Civil Rights - Civil Liberties Law Review, v. 42, 2007.

${ }^{220}$ BRANDÃO, 2012. 
Colocando-se, para tanto, à frente da opinião pública, como foi o caso da Suprema Corte americana em Brown v. Board of Education ${ }^{221}$.

É sistema, enfim, que Friedman vai chamar de constitucionalismo popular mediado, em que a Suprema Corte, na solução de disputas constitucionais, sofrerá a influência da opinião pública por meio dos mecanismos de reação política nas mãos dos outros Poderes. Não quer dizer, contudo, que não seja sua responsabilidade, em igual medida, sopesar entre vontades populares contingentes e momentâneas e aquelas de caráter permanente, para aprimorar a natureza deliberativa da solução de conflitos constitucionais ${ }^{222}$.

\subsection{O Brasil e os mecanismos de reação ao STF}

Segundo relata Rodrigo Brandão, o constitucionalismo brasileiro possui muitos exemplos de ataques institucionais ao Supremo Tribunal Federal. Só no governo de Floriano Peixoto (1891 a 1894), ele relata quatro. O primeiro cuida de caso em que indivíduos presos em protestos à assunção da presidência por Floriano Peixoto em face da renúncia de Deodoro da Fonseca (não ocorrendo por isso a convocação de novas eleições) manejaram Habeas Corpus ao Supremo para serem soltos. Os ministros da Corte foram ameaçados com o descumprimento da decisão e com sua prisão, caso os deferissem.

Há também o caso em que ofícios do Ministro da Guerra foram publicados no Diário Oficial comunicando ao STF a sua discordância quanto à decisão nos Habeas Corpus referentes à Revolução Federalista no Rio Grande do Sul. O terceiro caso cuida de circunstância em que o STF deferiu salvo-conduto em favor de estrangeiros envolvidos na Revolta da Armada para impedir que fossem expulsos do Brasil, medida tornada sem efeito com a emissão posterior, pelo governo de Floriano Peixoto, de Decreto de expulsão com data retroativa. Por último, tem-se o não preenchimento por longo período das cadeiras vagas no STF, dificultando seu funcionamento, após o que decidiu o Presidente indicar um médico e dois generais para as cadeiras vagas - desestabilizando em igual medida a atuação do Tribunal.

Ademais, há no Brasil dois exemplos marcantes de redução das competências do STF - a extinção do Habeas Corpus pela Reforma Constitucional de 1926, e a

\footnotetext{
${ }^{221}$ BRANDÃO, 2012.

${ }^{222}$ FRIEDMAN, Barry. Mediated Popular Constitutionalism. Michigan Law Review, 2003, v. 101.
} 
insindicabilidade judicial de questões políticas estabelecidas pela Constituição de 1937 (a polaca) ${ }^{223}$.

Dignos de menção também são os atos do Governo Provisório após a Revolução de 1930, reduzindo de 15 para 11 o número de ministros do STF e aposentando compulsoriamente seis ministros, o Ato-Institucional n. 2, de 27/10/1965, aumentando o número de ministros de 11 para 16 e suspendendo as garantias dos magistrados, e, por fim, a Constituição de 1937, que possibilitou ao Parlamento negar aplicação a decisões do STF, o que passou a ser feito pelo próprio Presidente Getúlio Vargas por meio de decretos-leis depois que o Legislativo foi fechado durante o Estado Novo.

Assim é que a utilização constante de referidos mecanismos impediu a efetiva instalação do controle de constitucionalidade antes do advento da Constituição de 1988, não havendo que se falar, no Brasil, em regime de supremacia judicial em sentido amplo e material $^{224}$. A relevância da Constituição e do próprio Judiciário no controle da validade de atos públicos e privados só se consolida a partir da Constituição de 1988. E para além da expansão progressiva do poder político do Judiciário ${ }^{225}$, estão positivadas na Carta de 1988 mecanismos de freios e contrapesos concedendo formas de controles de outros departamentos sobre o Judiciário.

Atribuiu-se ao Parlamento o poder de aprovar o orçamento dos Tribunais e os salários dos juízes. Com efeito, o Congresso não está vinculado à proposta orçamentária enviada pelo Judiciário, podendo aprovar orçamento menor (art. 165 da CF/1988).

Rodrigo Brandão destaca, nessa esteira, que "a influência do modelo norteamericano de nomeação e investidura dos juízes da Suprema Corte no Brasil é evidente, na medida em que também optamos por conferir a prerrogativa da nomeação dos juízes da Suprema Corte ao Presidente״ ${ }^{226}$, condicionada à posterior confirmação do Senado, e o vitaliciamento no lugar de mandatos fixos (com a diferença de que no Brasil dá-se a aposentadoria compulsória aos 70). Brandão, entretanto, defende que desde a primeira Constituição republicana (1891), a deliberação do Senado, via de regra, não passa de formalidade necessária à posse no cargo. O único caso de rejeição teria sido o de Barata Ribeiro, mais pelo fato de que era médico e não atendia ao requisito do notório saber

\footnotetext{
${ }^{223}$ BRANDÃO, 2012.

224 BRANDÃO, 2012.

225 Mencione-se a extensão do rol dos legitimados ativos para a propositura da ADI, a criação da ADC e a regulamentação da ADPF, a criação da súmula vinculante e da repercussão geral, a ampliação dos atos sujeitos ao controle de constitucionalidade abstrato etc.

${ }^{226}$ BRANDÃO, 2012, p. 263.
} 
jurídico. E nessa medida, torna-se curiosa a situação brasileira, onde, em que pese a atual expansão do poder político do STF, não se observa o correlato aumento da atenção dada pelos Poderes políticos e partidos às nomeações para a Suprema Corte, diferentemente do que ocorre nos Estados Unidos, onde os debates políticos em torno dos possíveis candidatos perpassam todas as suas inclinações ideológicas e status político (ou a ausência dele).

Sendo o modelo de investidura no Brasil, pois, caracterizado pela atuação quase que exclusiva do Presidente da República, o seu poder de nomeação influencia a própria evolução da jurisprudência constitucional do STF, em especial quando se trata de casos importantes para as coalizões na base do governo. Entretanto, quanto à reversão de linhas jurisprudenciais específicas, Brandão destaca ser reduzida a influência do processo de nomeação. Confira-se:

(...) em razão do reduzido número de questões constitucionais discutidas durante a sabatina no Senado, da falta de concomitância entre os momentos em que o assunto surge no STF e em que há vaga no Tribunal, de o fato de o processo de sabatina vir apresentando baixo nível deliberativo no Brasil, e de a vitaliciedade permitir que juiz fique longo período de tempo no STF, podese concluir que a influência do processo de nomeação para a reversão de linhas jurisprudenciais específicas é bastante reduzida ${ }^{227}$.

Outra característica no modelo de deliberação do STF está na opção por um modelo de deliberação externa, a exemplo da Suprema Corte americana. Na lição de Ferejohn e Pasquino $^{228}$, o modelo de deliberação preponderante adotado pelas Cortes Constitucionais europeias classifica-se como interno, já que as decisões são tomadas a portas fechadas, mediante reuniões com grande troca de informações e opiniões entre os juízes. Nesse ambiente recluso e afastado do olhar externo da mídia e da opinião pública, argumenta-se, os juízes se mostram mais aptos a fazerem concessões em relação à opinião original que professavam. A persuasão mútua entre os juízes, que possuem acesso à opinião de seus pares antes que qualquer voto seja redigido, torna incomum a existência de votos

\footnotetext{
${ }^{227}$ BRANDÃO, 2012, p. 264.

${ }^{228}$ FEREJOHN, John e PASQUINO, Pasquale. Constitutional Courts as deliberative institutions: towards an institutional theory of constitutional interpretation. In: SADURSK, Wojciech. Democratic legitimacy and constitutional Courts in post-communist Europe in a comparative perspective. Netherlands: Kluwer Law International, 2002.
} 
divergentes, permitindo à Corte a emissão de decisões, em regra, de natureza única, institucional, clara, objetiva e de consenso ${ }^{229}$.

Na realidade brasileira, contudo, não se costuma conhecer de antemão os votos dos ministros, que tampouco deliberam entre si, formando sua convicção no ambiente isolado de seus gabinetes. E como alerta Virgílio Afonso da Silva, o fato de estarem em um ambiente público, televisionado ao vivo, determina menor suscetibilidade à realização de concessões ou mudanças de opinião no meio do julgamento, sendo frequente a existência de votos divergentes - não para o convencimento dos pares, mas antes para plateias diversas, como os Poderes Legislativo e Executivo, os movimentos sociais, a academia e a mídia $^{230}$. E se a deliberação interna, não se pode negar, peca pela evidente falta de transparência, a deliberação externa sujeita os juízes à excessiva influência de câmeras, holofotes e observadores externos.

O que se quer, todavia, é ressaltar que o conjunto de votos particulares dissonantes dificultam a identificação e compreensão dos posicionamentos do STF por atores externos e Tribunais inferiores, além do que dissipam a força persuasiva presente em uma decisão unânime ${ }^{231}$.

Brandão levanta, ainda, o risco considerável de que entendimentos constitucionais do STF não produzam, de fato, efeito erga omnes e vinculante, e isso por duas razões. A primeira seria a tradição anterior à Constituição de 1988 de atribuição de efeitos inter partes às decisões de inconstitucionalidade, fazendo dos mecanismos de monitoramento da adequação das decisões dos Tribunais e dos atos da Administração Pública ao entendimento do STF instrumentos em estágio inicial de desenvolvimento. A segunda razão, por sua vez, funda-se no grande desconhecimento dos “motivos determinantes” nas decisões do STF, decorrente do hermetismo da linguagem jurídica, do fato de que não se colhem votos quanto aos fundamentos da decisão, mas tão-somente em relação ao dispositivo, e do modelo de deliberação externa que ali predomina, não favorecendo a prolação de decisões claras, objetivas e únicas ${ }^{232}$.

O autor aponta, por fim, a relativa facilidade do processo de emenda à Constituição no Brasil, se comparado ao americano, estimulando a resposta ao ativismo judicial por meio do ativismo legislativo. Mas reconhece também que a intrincada malha de interesses

\footnotetext{
${ }^{229}$ SILVA, Virgílio Afonso. O STF e o controle de constitucionalidade: deliberação, diálogo e razão pública. Revista de Direito Administrativo, n. 250, 2009.

${ }^{230}$ SILVA, 2009, p. 210.

${ }^{231}$ BRANDÃO, 2012.

232 BRANDÃO, 2012.
} 
políticos subjacentes ao processo legislativo, responsável pela alta fragmentação do poder político, determina a reserva de emendas superadoras de decisões do STF a atores políticos especialmente fortes, como o governo federal nas questões de impacto financeiroorçamentário, de natureza tributária ${ }^{233}$.

Para Marcus André Melo, a constitucionalização de uma determinada matéria não tem transformado o Judiciário em um agente de veto quanto a preferências centrais dos poderes políticos, mas vem relegando aos Tribunais a função de um "alarme de incêndio” ${ }^{234}$, atraindo a atenção da opinião pública para a questão. E isso porque os instrumentos de reação dos poderes políticos a decisões do STF vêm promovendo sincronização considerável de sua jurisprudência com a opinião pública, em especial nas questões politicamente sensíveis.

\section{O diálogo constitucional canadense e a teoria da construção coordenada}

A alusão à metáfora dos diálogos constitucionais vem sendo usada com razoável frequência para designar a tendência recente de priorizar a interação interinstitucional na definição de direitos, em oposição ao tradicional debate metodológico sobre "como" interpretar a Constituição. É mérito, como já salientado, do modelo teórico neoinstitucional.

Dentre os autores mais conhecidos que se imiscuíram na investigação do diálogo, devem ser destacados Peter Hogg e Allison Bushell, que deram início ao amplo debate canadense com seu artigo seminal: The Charter dialogue between courts and legislatures (or perhaps the charter isn't such a bad thing after all). Partiram da premissa de que a possibilidade de reversão legislativa de decisões da Suprema Corte faz do controle de constitucionalidade um instrumento catalisador do diálogo entre as instituições políticas para se encontrar a melhor forma de harmonizar liberdades individuais. O problema da dificuldade contramajoritária perderia aí muito de sua força.

A Carta Canadense de Direitos de 1982 seria, nesse sentido, grande facilitadora do diálogo, possibilitando ao legislador ordinário que imponha limites razoáveis aos direitos fundamentais na Seção 1 e estabelecendo a override clause na Seção 33. A constatação de

\footnotetext{
${ }^{233}$ BRANDÃO, 2012.

${ }^{234}$ MELO, Marcus André. Hiperconstitucionalização e Qualidade da Democracia, Mito e Realidade. In: MELO, Carlos Ranulfo; SAÉZ, Manuel Alcântara (orgs.). A Democracia Brasileira. Balanço e perspectiva para o século 21. Belo Horizonte: Editora UFMG, 2007, p. 257.
} 
que $80 \%$ das decisões constitucionais da Suprem Corte haviam gerado algum tipo de sequela normativa só confirmava, para os autores, a existência de efetivo diálogo na prática institucional do Canadá.

Kent Roach veio se alinhar à posição, e elegeu a Seção 1 como o instrumento, por excelência, dos diálogos constitucionais no Canadá, ao prever que a lei limite, por um lado, os direitos fundamentais, e, por outro, que a Suprema Corte controle a razoabilidade desses limites. Sobressairia, assim, o papel da Suprema Corte na proteção de direitos, e o papel do Parlamento em angariar e utilizar informações a respeito dos objetivos da regulação estatal e sua sintonia com a vontade popular ${ }^{235}$.

Todavia, quando o acordo entre Parlamento e Suprema Corte não for possível, sendo necessário definir questões práticas, Roach elegeu o Parlamento como detentor da última palavra por meio do uso da override clause. Seria mecanismo mais vantajoso que outros instrumentos de reação legislativa, porquanto seu alto custo político evitaria o uso corriqueiro, a relevância política de seu uso mostraria ao público a tentativa do Parlamento de superar decisão judicial, e o prazo de cinco anos da cláusula permitiria que o tema voltasse à discussão em um momento em que os ânimos estivessem menos exaltados.

Entre as duas perspectivas, a única diferença está na preconização de qual deve ser a postura da Suprema Corte quando o legislador, depois que lei foi declarada inconstitucional, prefere a edição de outra lei idêntica ao invés de usar o mecanismo da override clause. Para Hogg e Bushell, a Corte deve prestar deferência à nova medida ao aferir de novo a razoabilidade dos limites impostos ao direito fundamental, como se houvesse espécie de reforço na presunção de constitucionalidade da nova medida, ao passo que Roach acredita que a Suprema Corte deve refazer seu juízo prévio de inconstitucionalidade já lançado, não aceitando apreciar novamente a constitucionalidade da nova lei. Dessa forma estaria incentivando o uso da override clause pelo Parlamento, já que é uma parte da estrutura dialógica da Carta, e por isso deve ser utilizada ${ }^{236}$.

Fica evidente que os autores canadenses depositam grande esperança na capacidade do Judiciário de tutelar direitos de minorias sem voz no processo político. Mark Tushnet, contudo, veio questionar se o altíssimo custo político para se acionar a override clause não estaria, em verdade, apenas conferindo falsa roupagem dialógica a um desejo oculto de se

\footnotetext{
${ }^{235}$ ROACH, Kent. The Supreme Court on Trial: Judicial Activism or Democratic Dialogue. Irwin Law, 2001. ${ }^{236}$ ROACH, Kent. Sharpening the Dialogue Debate. Osgoode Hall Law Journal, v. 45, n. 1, 2007.
} 
optar pela supremacia judicial, ocultando também a crença na maior capacidade do Judiciário na proteção de direitos ${ }^{237}$.

É a partir dessa crítica que adeptos da chamada "teoria da construção coordenada" defendem papéis equilibradamente relevantes para o Judiciário e para o Legislativo na interpretação da Constituição. Os mecanismos prescritos pelos adeptos dessa linha teórica variam da não vinculação dos Poderes que discordam da decisão judicial ${ }^{238}$ à legitimação do Legislativo para superar decisões de inconstitucionalidade por meio de leis ordinárias (legislative override) $^{239}$.

Tanto a construção coordenada quanto a teoria dos diálogos constitucionais reconhecem que a interpretação constitucional constitui um processo longo, com a contribuição das instituições na forma de suas capacidades específicas e atuando com vistas à mútua acomodação de suas perspectivas. A diferença é que para o legislative override prescrito pela construção coordenada, as leis ordinárias superadoras de decisões da Suprema Corte não devem atuar apenas dentro do limite fixado pela Corte (como é o caso da override clause defendida pelo diálogo constitucional), mas também sobre esses limites, reiterando assim objetivos julgados inconstitucionais pela Suprema Corte. Assim é que novas leis idênticas àquelas já declaradas inconstitucionais pela Suprema Corte, passadas no Parlamento por nova maioria simples, seriam instrumento integrante da estrutura da Constituição. Não haveria que se falar em supremacia parlamentar, mas sistema de freios e contrapesos em que nenhuma instituição possui a última palavra ${ }^{240}$.

Rebatendo a tese de que a igualdade entre os órgãos estatais na interpretação constitucional promoveria a não vinculação dos Poderes executivo e Legislativo às decisões judiciais com que não concordassem, evoca-se a razão de ser do próprio Estado de Direito. Não é difícil perceber que a obrigatoriedade das decisões para as partes do processo encerra pressuposto necessário para a efetiva limitação dos poderes de agentes públicos e privados aos ditames da Constituição ${ }^{241}$. Retomar os efeitos tão-somente inter partes das decisões de inconstitucionalidade, por outro lado, também representaria um

\footnotetext{
${ }^{237}$ TUSHNET, Mark. Weak Courts, strong rights - Judicial Review and social welfare rights in comparative constitutional law. New Jersey: Princeton University Press, 2008.

${ }^{238}$ PAULSEN, Michael Stokes. The Irreprehensible Myth of Marbury. Michigan Law Review, n. 101, 2003.

239 BAKER, Dennis. Not quite Supreme: the courts and coordinate constitutional construction. Canada: McGill-Queen's University Press, 2010.

${ }^{240}$ BAKER, 2010.

241 POST, Robert e SIEGEL, Reva. Popular constitutionalism, departamentalism and judicial supremacy. California Law Review, v. 92, 2004
} 
retrocesso, transformando o Direito Constitucional em um corpo incoerente e desconexo de normas $^{242}$.

Quanto à possibilidade de que decisões constitucionais da Suprema Corte sejam superadas pelo Parlamento por meio de lei ordinária, Rodrigo Brandão alerta que tal cenário não promoveria a necessária distinção entre as políticas constitucional e ordinária. Para ele, referido modelo se aproxima por demais de uma supremacia parlamentar, com o risco de que o Parlamento se torne uma instituição soberana e prejudique direitos de minorias, bem como sua vinculação à Constituição ${ }^{243}$.

Admitindo-se, todavia, que a Suprema Corte possa também controlar a própria constitucionalidade da norma que reverteu a sua decisão pretérita, estaria estabelecido um diálogo saudável sobre a melhor forma de solucionar uma questão constitucional controvertida, com a contribuição de cada Poder na medida de seu perfil institucional.

Brandão manifesta, ainda, endosso à visão de Lipkin, para quem é necessário encontrar um procedimento mais rígido do que o processo legislativo ordinário nos casos de tentativa de "superação normativa” por parte do Parlamento, mas não tão rígidos como o processo de emenda à Constituição americana. Evitaria que se banalizasse o emprego da "superação normativa”, já que demandaria um forte consenso em sentido contrário à decisão judicial, mas, por outro lado, tornaria factível a mobilização e reunião dos votos necessários à reversão da decisão judicial. Para Lipkin, a maioria qualificada exigida pelo processo de emenda à Constituição americana impõe custo político altíssimo à superação explícita das interpretações constitucionais da Suprema Corte, resultando na prevalência da maior parte das decisões judiciais sem oposição efetiva ${ }^{244}$.

No entanto, atento aos aspectos práticos do dia-a-dia de uma comunidade política, e da necessidade de definições para o funcionamento eficiente do processo de realização e proteção de direitos em casos concretos, Frederick Schauer, em trabalho conjunto com Larry Alexander, insiste que regimes democráticos, ao contrário de seminários

\footnotetext{
${ }^{242}$ POST e SIEGEL, 2004.

243 Note-se, no ponto, que o medo explicitado pelo autor brasileiro quanto à ausência de distinção entre a política ordinária e a política constitucional não se alinha à ideia de constituição modesta professada por Frederick Schauer. Temer a supremacia parlamentar, por outro lado, e assumir que tal modelo necessariamente levaria à supressão de direitos de minorias é raciocínio que vai de encontro ao exemplo real do regime britânico, em que se busca resguardar direitos de minorias a despeito da soberania do Parlamento. Não se estar a negar que direitos de minorias poderiam sim estar em risco em modelos nos quais o Parlamento não sofre limitações pelos demais Poderes, o que não permite, contudo, afirmar que é corolário lógico da soberania parlamentar o recorrente desrespeito de direitos de minorias.

${ }^{244}$ LIPKIN, Robert Justin. What's Wrong with Judicial Supremacy? What's Right About Judicial Review? Widener Law Review, v. 14, n. 1, 2008.
} 
acadêmicos, não podem se perder em infindáveis debates ${ }^{245}$. Em nome da estabilidade social, é necessário que a deliberação em algum momento chegue ao fim, de modo que uma decisão coercitiva seja tomada pela autoridade competente. Nesse sentido, permitir que o Congresso aprove normas retroativas que desconstituam os efeitos de decisões de inconstitucionalidade transitadas em julgado criaria - salvo hipótese de flagrante erro judicial - uma anarquia interpretativa de efeitos deletérios para a segurança jurídica.

Para rebater essa objeção, Rodrigo Brandão vai afirmar que confundir controle de constitucionalidade com supremacia judicial, é dizer, entender que o entendimento judicial sobre o sentido de princípios constitucionais é imutável pelo Legislativo e pelo povo não parece razoável $^{246}$. Ao revés, seria fundamental para a realização dos pressupostos do Estado Democrático de Direito um desenho institucional que permita que instituições políticas, entre si e também em relação à sociedade civil, troquem impressões e contribuições para a modelagem das compreensões acerca de direitos, cada qual dentro de sua específica capacidade institucional. Por isso, admite-se a possibilidade de que respostas definitivas sejam dadas de tempos em tempos, pela necessidade de definições objetivas no dia-a-dia, como previram Schauer e Alexander, mas isso não significa que o diálogo tenha terminado por completo. Circunstâncias novas podem surgir, ou o espírito geral que animou aquela decisão específica pode se transformar - novas definições podem se fazer necessárias, e quem deverá determiná-las não é algo que se possa estipular de antemão.

Nessa medida, a grande vantagem das teorias do diálogo estaria em reconhecer as fraquezas e virtudes de cada ator institucional, confiando que a interação entre eles forçará maior autocontrole por parte de cada um, para o oferecimento de contribuições substantivas e de qualidade. O objetivo, portanto, é um processo deliberativo de maior higidez. Deve-se rejeitar, assim, a absolutização de critérios de pedigree e expertise (relegando a determinado Poder a responsabilidade absoluta pela confecção de determinada decisão em virtude de sua competência aprimorada), de acordo com os quais a capacidade institucional de um ator político levará necessariamente a decisões melhores, “como se tais ‘poderes’ fossem infalíveis” 247.

A reversão de uma decisão judicial reputada errônea depender da mudança de entendimento da Suprema Corte parece realmente não estimular a interpretação constitucional fora dos Tribunais. Em igual medida, a superação de uma lei que atente

${ }^{245}$ ALEXANDER, Larry e SCHAUER, Frederick. Defending Judicial Supremacy: a reply. 17 Const. Comment. 455, 458 n. 12, 2000.

${ }^{246}$ BRANDÃO, 2012, p. 287.

${ }^{247}$ BRANDÃO, 2012, p. 288. 
contra direitos de minorias depender da edição de nova lei em sentido contrário não estimula, de seu turno, a deliberação constitucional fora do Parlamento ${ }^{248}$. É esse o espírito estanque e segmentado do qual buscam se afastar as teorias dialógicas, sob pena de descambarem em raciocínios sustentados por noções puramente definitivas de "última palavra”.

A propósito, Marcelo Neves refere-se às mais diversas interações entre os Poderes em um sentido de "hierarquias entrelaçadas", apontando então um modelo de “circularidade procedimental” que faz do processo de realização da Constituição uma experiência interativa e gera a redução da complexidade nas deliberações públicas, porquanto apenas um procedimento central dificilmente chegaria a respostas satisfatórias às diversas controvérsias de uma sociedade hipercomplexa ${ }^{249}$.

\section{O Brasil e a verificação dos pressupostos dialógicos na prática institucional}

Adotar teorias que defendam algum tipo de "supremacia”, seja ela a judicial, seja ela a legislativa, reflete perspectivas idealizadas sobre o ator institucional que se quer privilegiar, e noções preconceituosas sobre aquele cuja atuação se deseja enfraquecer. É intuição generalizada que o Parlamento apresenta maior capacidade institucional para a concretização de políticas públicas, ao passo que o Judiciário detém maior capacidade institucional para a proteção de direitos fundamentais, situação que confere a ambas as instituições, prima facie, prioridade na concretização das respectivas normas constitucionais. Afirmar, contudo, que determinado agente possui maior capacidade institucional em determinada seara não significa aceitar que sua decisão nessa área será melhor, mas sim que provavelmente o será. Com efeito, dizer que uma interpretação será melhor ex ante não é possível, mas apenas após se analisar o seu conteúdo face à norma interpretada - é dizer, apenas em uma perspectiva ex post $t^{250}$.

\footnotetext{
${ }^{248}$ Assim sintetiza Brandão sua defesa do modelo dialógico: "Em síntese, acredita-se que um modelo dialógico articula de forma mais proveitosa o autogoverno do povo e os direitos fundamentais do que os modelos de supremacia, já que: (i) provê múltiplos pontos de acesso aos interessados em determinada questão constitucional, na medida em que eles poderão atuar perante instituições diversamente representativas (sobretudo o Judiciário e o Legislativo), o que promove o pluralismo e a democracia; (ii) reduz a oportunidade de atuação unilateral de quaisquer 'poderes', intensificando os mecanismos de freios e contrapesos, fator que tende a conter o exercício arbitrário do poder estatal” (BRANDÃO, 2012, p. 289).

${ }^{249}$ NEVES, Marcelo. Entre Têmis e Leviatã: uma relação difícil. São Paulo: Martins Fontes, 2008.

${ }^{250}$ DEVINS, Neal. Congress Fact Finding and the Scope of Judicial Review: A Preliminary Analysis. 50 Duke L. J. 1169, 1172-76, 2001.
} 
É, pois, com esse intuito analítico em mente que se parte ao exame empírico da atuação do STF e do Congresso em casos específicos, para que se possa, se não for possível obter uma conclusão definitiva quanto à existência, no Brasil, da prática dos diálogos constitucionais, ao menos investigar se o desenho institucional do sistema constitucional brasileiro permite o desenvolvimento mínimo de credenciais normativas dialógicas.

Para tanto, o caso ora enfocado será o do RE 166.772, em que o STF interpretou a expressão "folha de salários" (art. 195, inciso I, CF/1988) em seu sentido mais técnico e vernacular possível, excluindo assim a incidência de contribuição previdenciária em relação aos trabalhadores que não mantivessem vínculo empregatício com o tomador de serviços.

Os efeitos de referida decisão no Regime Geral da Previdência Social foram, como era de se esperar, desastrosos. Os autônomos, que até aquela decisão judicial pagavam a contribuição social, deixaram de pagá-la e ganharam o direito de repetir o indébito, sem, contudo, perder o direito aos benefícios previdenciários já adquiridos. O prejuízo financeiro ao Tesouro foi imenso e, sob a perspectiva da justiça social, constatou-se não significar qualquer avanço dos direitos dos trabalhadores ${ }^{251}$. Ao contrário, provocou desequilíbrio atuarial e consequente oneração dos que seguiram sujeitos à incidência do tributo, sem que houvesse qualquer critério moral ou político a justificar tal decisão.

A solução à celeuma veio então pelas mãos do Parlamento na forma da Emenda Constitucional n. 20, de 15 de dezembro de 1998, que acrescentou à expressão folha de salários a seguinte redação: "e demais rendimentos do trabalho pagos ou creditados, a qualquer título, à pessoa física que lhe preste serviço, mesmo sem vínculo empregatício”.

Também para superar entendimento do STF acerca da não incidência de ICMS sobre a importação de bens por pessoa física, foi confeccionada a Emenda Constitucional n. 33, de 2001. O entendimento da Corte Suprema foi firmado em iguais bases formalistas na interpretação das expressões "circulação de mercadorias e estabelecimento" (art. 155, $\S 2^{\circ}$, inciso IX, alínea “a”, CF/1988), emprestando-lhe o sentido técnico que o Direito Empresarial confere ao termo para limitar o rol de contribuintes aos indivíduos que praticassem atos de comércio com habitualidade ${ }^{252}$.

251 TORRES, Ricardo Lobo. Tratado de direito constitucional financeiro e tributário. Rio de Janeiro: Renovar, 2005, v. II.

${ }^{252}$ RE 203.075, STF, Pleno, julgamento em 05/08/1998, DJ 29/10/1999. 
Para Ricardo Lobo Torres, a decisão desconsiderou os pressupostos científicos e jurídicos dos impostos sobre o valor acrescido, indo em direção contrária à prática de outros países que adotam o IVA e com os quais o Brasil mantém relação comercial. No Brasil e no exterior adota-se o princípio do país de destino para a cobrança de impostos sobre o valor agregado (como o ICMS), com vistas a desonerar as exportações e permitir sua incidência nas importações para igualar os preços das mercadorias estrangeiras e nacionais $^{253}$.

Os efeitos maléficos da decisão consistiram no enriquecimento ilícito de quem se apropriou do imposto de que o país exportador abriu mão, na criação de distinção inconstitucional entre brasileiros, já que quem adquiriu a mercadoria estrangeira no comércio brasileiro arcou com o ônus do tributo, e, ainda, no prejuízo à Fazenda, pois na hipótese inversa de exportação para pessoa física residente no estrangeiro, a mercadoria saia livre de ICMS, permitindo a incidência do tributo do país de destino ${ }^{254}$.

O foco aqui não está no desacerto ou não de referidas decisões, mas no fato de que o Congresso procedeu à superação normativa dessas decisões proferidas pelo STF, para estancar os efeitos deletérios que exerciam sobre o Regime da Previdência Social e sobre a tributação de bens importados, respectivamente. Não se está a mitificar e enaltecer a atuação do Congresso, nem a depreciar o STF na prolação das decisões em questão, mas a reconhecer que uma decisão do Judiciário instigou uma resposta legislativa de qualidade, abrindo espaço a uma espécie de interação entre Poderes que levou a uma interpretação constitucional mais adequada do que aquela produzida pela atuação unilateral de apenas um deles.

A propósito, destaca Rodrigo Brandão que, no Brasil, a observação da dinâmica das relações institucionais na interpretação da Constituição revela que o mecanismo típico de superação da jurisprudência constitucional do STF pelo Congresso é a aprovação de emenda constitucional $^{255}$. Como exemplos, por todos, citem-se três casos.

No RE 153.771, o STF afirmou que o IPTU teria natureza real, de modo que a Constituição somente permitiria a fixação de alíquotas progressivas para o atendimento da finalidade extrafiscal de adequação do uso da propriedade urbana a sua função social (art. 182, CF/1998). Veio então a Emenda Constitucional n. 29, de 2000, e alterou a redação do art. 156, $\S 1^{\circ}$, da CF/1988 permitindo que o IPTU “seja progressivo em razão do valor

\footnotetext{
${ }^{253}$ TORRES, 2005, v. IV.

${ }^{254}$ TORRES, 2005, v. IV.

${ }^{255}$ BRANDÃO, 2012.
} 
venal do imóvel”, precisamente a progressividade de natureza fiscal pretendida pelas leis municipais anteriormente invalidadas pelo STF.

O segundo caso cuida de diversas leis municipais julgadas inconstitucionais pelo STF ao instituírem taxas de iluminação pública, ao argumento de que a iluminação pública não consistiria serviço público específico e divisível, a ser remunerado mediante a espécie tributária da taxa. O Congresso Nacional, todavia, convicto da necessidade de que valores fossem pagos pelo serviço em questão, aprovou a Emenda Constitucional n. 39, de 2002, instituindo assim a contribuição para o custeio da iluminação pública.

O último caso, por fim, traz a decisão proferida pelo STF na ADI $14^{256}$, em que afirmou que a expressão “quaisquer vantagens”, na redação original do art. 37, inciso XI, da CF/1988, não incluiria as vantagens de caráter pessoal para fins de computar o teto remuneratório. Foi aprovada então a Emenda Constitucional n. 19, de 1998, inserindo justamente tais vantagens de natureza pessoal no cômputo do teto remuneratório. Em sessão administrativa de 24/06/1998, contudo, o STF decidiu que o novo teto não seria autoaplicável, dependendo de edição de lei de iniciativa conjunta do Presidente da República, das Casas Legislativas e do STF, na forma da antiga redação do art. 48, inciso XV, da CF/1998. A evolução da questão não pararia aí.

Em 2003, o Congresso aprovou a Emenda Constitucional n. 41, que, além de manter expressamente as vantagens pessoais no cômputo do teto remuneratório, determinou a autoaplicabilidade do referido teto e rejeitou o argumento de direitos adquiridos. Entretanto, no julgamento do MS $24.875^{257}$, o STF, por seis votos a cinco decidiu que a garantia de irredutibilidade de vencimentos era modalidade qualificada de direito adquirido, determinando que os vencimentos consolidados anteriormente à EC $\mathrm{n}$. 41/2003 em valores nominais superiores ao teto não poderiam sofrer o corte correspondente.

Mais acima foram relatados casos em que a atuação posterior do Congresso brasileiro aprimorou a interpretação constitucional fornecida pelo STF, mas o contrário também pode ser observado na experiência da Corte Suprema brasileira - é dizer, casos existem em que a intervenção do Supremo Tribunal Federal aprimorou a qualidade da interpretação constitucional levada adiante pelo Congresso Nacional.

\footnotetext{
${ }^{256}$ STF, ADI 14, DJ 01/12/1989.

${ }^{257}$ STF, Pleno, Mandado de Segurança n. 24.875, Rel. Min. Sepúlveda Pertence, julgamento em 11/05/2006, DJ 06/10/2006.
} 
No caso dos Municípios, mais de uma década se passou da aprovação da EC n. 15/1996 sem que o Congresso tenha cumprido seu dever de editar a lei complementar exigida pela atual redação do art. $18, \S 4^{\circ}$, da CF/1998, relativa à aprovação de critérios nacionais únicos para a criação de Municípios. A inércia do Congresso Nacional certamente produz efeitos ruins, pois além de tornar inconstitucional uma ação permitida pela Constituição (a criação de Municípios), inviabiliza que a criação de Municípios sujeite-se a critérios nacionais unificados, observando-se atual situação de proliferação desordenada em face de disciplinas jurídicas diversas conferidas pelas respectivas legislações estaduais.

O STF, assim, reconheceu na ADI 3.682-3 $3^{258}$ a inconstitucionalidade por omissão do Congresso Nacional e fixou prazo para a edição da referida lei complementar, dando contribuição importante para a supressão desse estado de mora legislativa. O Congresso deixou transcorrer em branco o prazo estipulado sem a lei complementar tão desejada, mas não se pode afirmar ter sido em vão a "prescrição" que lhe receitou o STF: aprovou a Emenda Constitucional n. 57, de 2008, convalidando os Municípios criados até 31/12/2006. Não foi a resposta satisfatória, mas pelo menos foi obrigado a se manifestar sobre esse tema controvertido, o que poderia nem ocorrer caso o STF não tivesse colocado o tema em destaque na agenda pública.

No último exemplo a ser analisado nessa pesquisa, tem-se o caso Mira Estrela, em que se observa intervenção igualmente positiva do STF em sua interação com o Congresso Nacional. As Câmaras Municipais vinham interpretando a Constituição no sentido de que haveria, para elas, discricionariedade na escolha do número de vereadores, contanto que observassem os limites mínimos e máximos estabelecidos pela redação original do art. 29, inciso IV, da CF/1988. O STF decidiu então que isso iria de encontro à regra da proporcionalidade, permitindo que Municípios menos populosos tivessem mais vereadores que Municípios mais populosos ${ }^{259}$.

O Congresso, é bem verdade, influenciado pelas forças políticas locais, aprovou a Emenda Constitucional n. 58, de 2009, que, na prática, recriou os cargos de vereadores extintos pela decisão do STF. Mas o fato de que a emenda em questão contemplou a redução dos gastos das Câmaras de Vereadores indica que a decisão do STF inseriu na agenda pública o tema da razoabilidade dos gastos dos Poderes legislativos municipais. A atenção crítica que imprensa e opinião pública conferiram à intenção do Congresso de

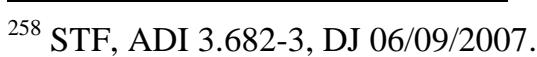

${ }^{259}$ STF, Pleno, RE 197.917, Rel. Min. Maurício Corrêa, julgamento em 06/06/2002, DJ 07/05/2004. 
aumentar o número de cargos de vereadores elevou o custo político da medida, inviabilizando que sua aprovação implicasse aumento dos repasses orçamentários às Câmaras de Vereadores.

Está, pois, comprovada a possibilidade de que o modelo político brasileiro forneça os instrumentos de design institucional necessários à aplicação das credenciais normativas do diálogo constitucional - o Parlamento "falando" por meio de emendas constitucionais e a Suprema Corte “conversando” pela via do controle de constitucionalidade. A solução fomentada pela interação apresentou, sem dúvidas, resultados que realizaram de forma mais completa as potencialidades constitucionais.

O STF agregou a necessidade de fidelidade ao texto e a conceitos jurídico-formais, para compatibilizar a vontade política de maiorias legislativas com as tradições constitucionais do país. O Congresso, por sua vez, com sua atuação mais voltada para a eficiência e para a amplitude das medidas - sem se desconsiderar sua maior abertura a informações e à atuação de grupos de interesse -, obteve sucesso em enxergar os efeitos práticos prejudiciais de certas decisões do STF, de modo que as superou ${ }^{260}$.

Haverá casos da experiência brasileira em que a decisão judicial quanto à constitucionalidade nada ou pouco agregará à concretização efetiva da Constituição e aprimoramento do processo político, bem como existirão, como já existem, emendas constitucionais cujo objetivo não é corrigir efeitos ruins de decisões judiciais. O que se buscou com a análise dos casos citados foi jogar luz sobre esse aspecto da atuação tanto da Corte como do Parlamento. É um enfoque que permite entrever potenciais caminhos construtivistas e ricos em benefícios mútuos, à medida que cada Poder busca extrair do outro o melhor que ele tem para oferecer, impulsionando sua atuação adiante ou sinalizando que ela deva ser refreada. Sobressai, pois, a tentativa de evitar précompreensões parciais da capacidade institucional de Judiciário e Legislativo, separadamente, como se costuma ver nas profusas narrativas que privilegiam um ator institucional em detrimento do outro.

${ }^{260}$ BRANDÃO, 2012. 


\section{- CONSIDERAÇÕES FINAIS -}

Já observou Mangabeira Unger que a maestria no pensamento é a marca de períodos nos quais uma nova leva de ideias é apresentada por aqueles que se encontram ocupados com a resolução de certos problemas, em diferentes áreas do conhecimento. Eles descobrem então que esses problemas estão conectados uns aos outros. E descobrem também que a fonte da incompreensão está nas premissas fundadoras das disciplinas cujos limites vinham lhes servindo de parâmetro. Enfim, eles estabelecem um novo sistema de ideais que varre aquelas dificuldades embora ${ }^{261}$.

E é assim, propondo a reformulação de premissas fundadoras, que o presente trabalho vem oferecer sua contribuição, ainda que modesta. Muito em função da própria natureza humana, tendente a encontrar divisões maniqueístas para aplacar sua sede por contornos e definições, arraigou-se na doutrina e na prática política dos dias atuais uma lógica de pensamento que, na análise normativa do funcionamento de uma instituição estatal, construiu sua base de legitimidade à custa da base de outra: para que uma obtenha as credenciais necessárias à atuação ideal, compare-a a outra que segue na mesma trilha, buscando também seus pressupostos de validação, e perceba quão mais aprimorada é sua capacidade de atingir os objetivos desejados.

Nos primórdios da Teoria Constitucional, a grande estrela era a própria Constituição. Soberana não apenas pelo papel fundador da comunidade política, mas

${ }^{261}$ UNGER, Roberto Manguabeira. Knowledge and Politics. United States of America: Free Press, 1975. 
também por sobrepor-se a qualquer outro instrumento normativo voltado a compreender as aspirações humanas, e, em última medida, a busca pela felicidade. Passado um tempo, consolidou-se a Jurisdição Constitucional ${ }^{262}$, a agora nova vedete do momento. Centrada no Poder Judiciário, confunde-se por vezes com os próprios agentes que a exercem. E porque se criou um sistema de divisão de atribuições na condução do dia-a-dia de uma comunidade política (a separação de poderes) - com a consequente segmentação de atores políticos -, o potencial para comparações, medições e classificações hierárquicas é quase que interminável. Legislativo e Judiciário. Porque o primeiro, porque não o segundo. E vice-versa.

Nessa esteira, procurou-se, mediante a pesquisa aqui empreendida, entender as raízes da revisão judicial em solo norte-americano, que foi de onde o instituto ganhou seus contornos para então ser adotado por diversos sistemas constitucionais mundo afora. Surpreende, certamente, constatar que o Poder Judiciário nos Estados Unidos recebeu dos fundadores da República funções ligadas ao controle da vontade popular, cujo fortalecimento nem sempre convinha aos interesses daqueles no poder. Mais adiante, a pesquisa buscou entender as motivações políticas na base da própria asserção do controle de constitucionalidade como prática condizente com os fundamentos daquele sistema jurídico, constatando, na questão, que a intenção de perpetuar valores ideológicos e políticos não deixou de figurar em Marbury v. Madison.

Repassadas, pois, as bases extrajurídicas subjacentes à consolidação do instituto, para demonstrar que não apenas por parâmetros legais se pautam aqueles exercendo funções públicas, argumentou-se que, a despeito de sua origem, a jurisdição constitucional não se tornou mero instrumento a serviço de projetos políticos, mas ganhou força própria, desvinculada de uma agenda partidária específica, razão por que a discussão em torno de sua legitimidade não carrega ambições ideológicas definidas, como se argumentou no final do capítulo 1. Todavia, por meio dela ainda assim não se deixa de entrever em certa medida o perfil dos atores institucionais responsáveis por seu exercício, em manifestações muitas vezes pautadas tanto por critérios legais quanto por critérios ideológicos.

O modelo neoinstitucional, nesse ponto referente à análise comportamental de agentes políticos, evidencia a insuficiência do modelo legal e do modelo atitudinal, por si só. A formação ideológica de cada agente considerado em si, assim como as balizas do sistema legal correspondente, bem por certo orientam sua atuação - cumpre ao referido

${ }^{262}$ Refere-se aqui, por óbvio, aos sistemas nacionais que a adotam. 
modelo analítico, contudo, relegar atenção ao perfil institucional em que inseridos tais atores e a dinâmica entre eles, identificando todo um contexto de ações e reações no cenário dos Poderes estatais.

Virtudes e defeitos no perfil de cada uma das instituições em foco - Cortes e Parlamentos - são de fato numerosos, tanto de um quanto de outro, como se pôde observar de todas as razoáveis críticas compiladas ao longo do capítulo 2. E isso porque não se pode falar em interação entre instituições sem antes se ter uma completa visão de sua realidade, para o bem e para o mal. É de noções realistas que as teorias do diálogo se alimentam, porquanto a força da interação desejada estará na própria essência de sua natureza. E nesse mister, em nome da linha de comunicação a ser identificada e refinada entre as instituições, considera-se até mesmo a possibilidade do papel menos central a todo o sistema legal de uma Constituição, nos termos sugeridos por Frederick Schauer na ideia da “constituição modesta”(capítulo 2).

E está-se, enfim, diante das vastas ramificações oferecidas pela perspectiva dialógica. Seja por meio de instrumentos de interferência no funcionamento administrativo dos Tribunais (a exemplo da aprovação de seu orçamento e do salário de juízes), seja por meio da compreensão da dinâmica decisória em si (o que se analisou à luz da teoria da escolha racional), o fato é que a linha de ação engendrada por um Poder repercutirá na atuação do outro, provocando alguma espécie de reação ou mesmo a definição de uma linha própria de ação. Esse canal de comunicação é fato que já existe, lançar luz sobre o fenômeno e torná-lo objeto de análise parece tarefa inadiável.

Tudo é transitório, nada permanece como está. Mas a transitoriedade, em sua apreensão pelo ser humano, ganha contornos definitivos. E então parte-se para a busca de verdades, a tentativa maior de se esquivar da natureza efêmera de tudo quanto nos rodeia, inclusive nós mesmos. Esculpir verdades, portanto, está na fibra de todo tipo de raciocínio, por mais cético que se queira fazer parecer. Não sendo possível fugir desse padrão, então resta apropriar-se da forma mais idônea possível de obter tais verdades, considerando-se a si mesmo e ao outro com a mesma medida de respeito.

Para John Stuart Mill, o melhor mecanismo de se chegar a soluções verdadeiras é por meio da exposição de uma proposição a amplo e honesto debate público, imiscuindo-se em suas virtudes e fraquezas na maior extensão possível. As verdadeiras ideias serão 
aquelas que resistirem às mais variadas críticas. As soluções, por outro lado, escondidas do escrutínio e por isso incontestadas morrerão como dogmas ${ }^{263}$.

Envolver maior número de atores políticos nos debates acerca de direitos, note-se, é o objetivo das teorias que enfocam o diálogo institucional. Deixa-se de lado a noção de que um pode mais ou menos que o outro, para concentrar-se no resultado da decisão que está sendo confeccionada, não se olvidando que a legitimidade e a satisfatoriedade dessa decisão também irão variar com o passar do tempo. Cuida-se da provisoriedade de resultados que a democracia deliberativa não ignora.

As instituições políticas, nessa medida, estão unidas indo em direção a um mesmo objetivo, e não se chocando uma contra a outra. Todavia, alertam, o diálogo não pode mostrar-se interminável, porque aí sofrem a segurança jurídica e a necessidade prática de pequenas mas essenciais definições. E interminável não será. Haverá momentos em que prevalecerá uma resposta, não porque foi proferida por essa ou outra autoridade, mas porque é a que melhor serve às necessidades coletivas legítimas do presente, sendo ela favorável ou mesmo contrária aos interesses das maiorias. O que não se pode perder de vista é que tal decisão não será definitiva se compreendida no grande cenário que é a caminhada de uma sociedade rumo ao futuro, com mudanças sempre por vir.

E se começamos com ele as considerações finais, com ele também terminaremos. Seguindo com Mangabeira Unger no ciclo do conhecimento, mudadas estão as premissas sobre as quais se opera e tem-se em mãos um novo sistema de ideias. Tal sistema logo se torna dominante. E aí começa, ele também, a desmantelar-se. Isso porque sua formulação encoraja a investigação de um mundo de possibilidade que antes nem se imaginava possível. Noções antes descartadas como simples e claras agora viram desafios que demandam solução. O pensamento segue sendo refinado. Suas limitações e defeitos, escondidos em seu nascimento, agora afloram e captam a atenção de mais e mais estudiosos. Assim, a linha de pensamento com a qual se trabalhava vira agora uma prisão de paradoxos e problemas.

Esse é o destino das ideias em geral, o destino, por certo, das ideias aqui expostas. Não deve impedir, contudo, que sigamos a trilha pela qual nos levam. Os frutos colhidos podem ser valiosos, ainda que por um período limitado de tempo.

\footnotetext{
${ }^{263}$ MILL, John Stuart. On Liberty. Chicago: Encyclopaedia Britannica, 1952 (Great books of the Westernworld).
} 


\section{- BIBLIOGRAFIA -}

ACKERMAN, Bruce. The Storrs Lectures: Discovering the Constitution. Yale Law Journal, v. 93, 1984.

ALEXANDER, Larry e SCHAUER, Frederick. Defending Judicial Supremacy: a reply. 17 Const. Comment. 455, 458 n. 12, 2000.

ALLAN, T.R.S. Law, Liberty, and Justice: The Legal Foundations of British Constitutionalism. 20 Oxford Journal of Legal Studies, 1993.

ARAÚJO, Cícero. Representação, retrato e drama. Lua Nova, v. 67, 2006.

BAKER, Dennis. Not quite Supreme: the courts and coordinate constitutional construction. Canada: McGill-Queen’s University Press, 2010.

BARNES, Jeb. Overruled? Legislative overrides, pluralism and contemporary CourtCongress relations. Stanford: Stanford University Press, 2004.

BARROS, Sérgio Resende de. Contribuição dialética para o constitucionalismo. São Paulo: Editora Millennium, 2008.

BEARD, Charles. The Supreme Court and the Constitution. Reprinted by Paisley Press, 1938.

BEÇAK, Rubens. A Hipertrofia do Executivo Brasileiro: o impacto da constituição de 1988. São Paulo: Própria, 2007.

BENTON, Wilbourn E. 1787: Drafting the Constitution, vol. II. United States of America: Texas A\&M University Press, 1986.

BICKEL, Alexander M. Foreword: the passive virtues. Harvard Law Review, v. 75, 1961.

. The Least Dangerous Branch: The Supreme Court at the Bar of Politics, $2^{\text {a }}$ Ed. New Haven and London: Yale University Press, 1986.

BORK, Robert. Neutral principles and some first amendments problems. Indiana Law Journal, n. 47, 1971.

BOYD, Julian P. "First Inaugural Address”, 04 de março de 1801 in Jefferson, Papers, ed. Princeton University Press, v. 33, 1950.

BRANDÃO, Rodrigo. Supremacia Judicial versus Diálogos Constitucionais. Rio de Janeiro: Lumen Juris, 2012. 
BURNS, James MacGregor. Packing the Court: The Rise of Judicial Power and the Coming Crisis of the Supreme Court. United States of America: Penguin Books, 2009.

CAGGIANO, Monica Herman. Democracia x Constitucionalismo - Um navio à deriva, artigo em homenagem ao Professor Celso Lafer, São Paulo, 2010.

CUSHMAN, Barry. The Secret Lives of the Four Horsemen. Virginia Law Review, vol. 83, n. 3, 1997.

DAHL, Robert A. Decision-Making in a Democracy: The Supreme Court as a National Policymaker. Journal of Public Law, v. 6, 1957.

. How Democratic is the American Constitution? $2^{\text {a }}$ Ed. New Haven \& London: Yale University Press, 2003.

DEVINS, Neal. Congress Fact Finding and the Scope of Judicial Review: A Preliminary Analysis. 50 Duke L. J. 1169, 1172-76, 2001.

DWORKIN, Ronald. Freedom's Law: a Moral Reading of the American Constitution. Cambridge: Harvard University Press, 1996.

. Justice for Hedgehogs. Cambridge, Massachusetts: The Belknap Press of Harvard University Press, 2011.

EDLIN, Douglas E. From Ambiguity to Legality: The Future of English Judicial Review. 52 Am. J. Comp. L. 3832004.

EKIRCH Jr. e ARTHUR A. Democracia Americana: Teoria e Prática. Trad. de Álvaro Cabral, Constantino Paleologo. Rio de Janeiro: Zahar, 1965.

ESKRIDGE Jr. e WILLIAM N. Overriding Supreme Court Statutory Decisions. Yale Law Journal, v. 101, n. 2, 1991.

FEREJOHN, John e PASQUINO, Pasquale. Constitutional Courts as deliberative institutions: towards an institutional theory of constitutional interpretation. In: SADURSK, Wojciech. Democratic legitimacy and constitutional Courts in post-communist Europe in a comparative perspective. Netherlands: Kluwer Law International, 2002.

FISHER, Louis. Constitutional dialogues - interpretation as a political process. Princeton University Press, 1988.

FRIEDMAN, Barry. Dialogue and Judicial Review. Michigan Law Review, v. 91, 1993.

2003. Mediated Popular Constitutionalism. Michigan Law Review, v. 101, . The Politics of Judicial review. Texas Law Review, v. 84, n. 2, 2005.

The will of the people: how public opinion has influenced the Supreme Court and shaped the meaning of the Constitution. New York: Farrar, Strauss and Giroux, 2009. 
GARGARELLA, Roberto. La Revision Judicial y la Dificil Relacion DemocraciaDerechos, Fundamentos y Alcances de Control Judicial de Constitucionalidad: Investigacion Colectiva del Centro de Estudios Institucionales de Buenos Aires. Madrid: Centro de Estudios Constitucionales, 1991.

La Justicia Frente ao Gobierno: Sobre el Carácter Contramayoritário del Poder Judicial. Barcelona: Editorial Ariel S.A., 1996.

Full Representation, Deliberation and Impartiality. In: ELSTER, Jon (Ed.). Deliberative Democracy. Cambridge: Cambridge University Press, 1998.

GINSBURG, Tom. Judicial Review in New Democracies - Constitutional Courts in Asian Cases. Cambridge University Press, 2003.

GOLDSWORTHY, Jeffrey. The Sovereignty of Parliament: History and Philosophy. Oxford: Clarendon Press, 1999.

GRONER, Jonathan. Election Fight Lights Spark Under the Right. Legal Times, 04 de dezembro de 2000.

HANSFORD, Thomas G. e DAMORE, David F. Congressional preferences, perceptions of threat, and Supreme Court decision making. American politics quarterly, v. 28, n. 4, 2000 .

HIEBERT, Janet. Limiting rights: the dilema of judicial review. Québec: McGill-Queens University Press, 1996 e Charter conflicts: what is Parliament`s role? Québec: McGillQueens University Press, 2004.

HOBBES, Thomas. O Leviatã. Org. Richard Tuck. Trad. de João Paulo Monteiro e Maria Beatriz Nizza da Silva. São Paulo: Martins Fontes, 2003.

HOGG, Peter; BUSHELL, Alison. The Charter Dialogue Between Courts and Legislatures (Or Perhaps the Charter of Rights Isn't Such a Bad Thing After All). Osgoode Hall Law Journal, v. 35, n. 1, 1997.

JOHNSON, Herbert A. “To a Freeholder”, 02 de outubro de 1798 in Marshall, Papers, ed. University of North Carolina Press, v. 10, 1974-2006.

KATYAL, Neal Kumar. Justices as Advicegivers. Stanford Law Review, v. 50, 1997.

KENT, James. An introductory Lecture to a Course of Law Lectures in Charles Hyneman and Donald S. Lutz, eds. American Political Writing During the Founding Era, vol. II: Liberty Press, 1983.

KISHLANSKY, Mark A. Parliamentary Selection: Social and Political Choice in Early Modern England, Cambridge: Cambridge University Press, 1986.

KNOPFF, Rainer. Courts Don`t Make Good Compromises. Policy Options, April, 1999. 
KYVIG, David E. The Road Not Taken: FDR, the Supreme Court, and Constitutional Amendment. Political Science Quarterly, v. 104, n. 3, 1989.

LAWSON, Gary \& MOORE, Christopher D. The Executive Power of Constitutional Interpretation. 81 IOWA L. Rev. 1276, 1996.

LINCOLN, Abraham. First Inaugural Address, in 4 The Collected Works of Abraham Lincoln 262, 268 (Roy P. Basler ed.), 1953.

LIPKIN, Robert Justin. What's Wrong with Judicial Supremacy? What's Right About Judicial Review? Widener Law Review, v. 14, n. 1, 2008.

MADISON, James; HAMILTON, Alexander; JAY, John. Os Artigos Federalistas (17871788). Trad. De Maria Luiza X. de A. Borges. Rio de Janeiro: Nova Fronteira, 1993.

MALBERG, R. Carré de. Teoria General del Estado. Tradução: José Lión Depetre. Ciudad de Mexico: Fondo de Cultura Económica, 2001.

MANIN, Bernard. The Principles of Representative Government, Cambridge: Cambridge University Press, 1997.

MAYHEM, David. Congress: The Electoral Connection. New Haven: Yale University Press, 1975.

MEESE, Edwin. The Law of the Constitution. 61 TUL. L. REV. 979, 1987.

MELO, Marcus André. Hiperconstitucionalização e Qualidade da Democracia, Mito e Realidade. In: MELO, Carlos Ranulfo; SAÉZ, Manuel Alcântara (orgs.). A Democracia Brasileira. Balanço e perspectiva para o século 21. Belo Horizonte: Editora UFMG, 2007.

MENDES, Conrado Hübner. Direitos Fundamentais, separação de poderes e deliberação. São Paulo: Saraiva, 2011.

MICHELMAN, Frank. Traces of Self-Government. Harvard Law Review, v. 100, 1986.

MILL, John Stuart. On Liberty. Chicago: Encyclopaedia Britannica, 1952 (Great books of the Westernworld).

MILLER, Mark C. The view of the courts from the hill: a neo institutional perspective. In: MILLER, Mark C. \& BARNES, Jeb (ed.). Making policy, making law: an interbranch perspective. Washington, DC: Georgetown University Press, 2004.

NEVES, Marcelo. Entre Têmis e Leviatã: uma relação difícil. São Paulo: Martins Fontes, 2008.

NINO, Carlos Santiago. The Constitution of Deliberative Democracy. New Haven \& London: Yale University Press, 1996.

PATTERSON, James T. Congressional Conservatism and The New Deal: The Growth of the Conservative Coalition in Congress, 1933-1939. University of Kentucky Press, 1967. 
PAULSEN, Michael Stokes. The Most Dangerous Branch: Executive Power to Say What the Law is. 83 GEO. L.J. 217, 1994.

n. 101, 2003.

. The Irreprehensible Myth of Marbury. Michigan Law Review,

PICKERILL J. Mitchell. Constitutional Deliberation in Congress: the Impact of Judicial Review in a Separated System. Duke University Press, 2004.

PITKIN, Hannah Fenichel. The Concept of Representation. Berkeley: University of California Press, 1967.

POST, Robert e SIEGEL, Reva. Popular constitutionalism, departamentalism and judicial supremacy. California Law Review, v. 92, 2004.

. Democratic Constitutionalism and Backlash. Harvard Civil Rights - Civil Liberties Law Review, v. 42, 2007.

ROACH, Kent. The Supreme Court on Trial: Judicial Activism or Democratic Dialogue. Irwin Law, 2001.

$1,2007$.

Sharpening the Dialogue Debate. Osgoode Hall Law Journal, v. 45, n.

ROSERNBERG, Gerald. The Hollow Hope: Can Courts Bring About Social Change? Chicago: University of Chicago Press, 1993.

SCHAUER, Frederick. Judicial Supremacy and the Modest Constitution. California Law Review, v. 92, 2004.

SCHELLING, Thomas C. Enforcing Rules on Oneself. 1 J.L. Eco. \& Org. 357, 1985.

SCHMITT, Carl. A crise da democracia parlamentar. São Paulo: Scritta, 1996.

SHAPIRO, Ian. The State of Democratic Theory. Princeton: Princeton University Press, 2006.

SILVA, Virgílio Afonso. O STF e o controle de constitucionalidade: deliberação, diálogo e razão pública. Revista de Direito Administrativo, n. 250, 2009.

SILVA RAMOS, Elival Da. Ativismo Judicial - Parâmetros Dogmáticos. São Paulo: Saraiva, 2010.

SPAETH, Harold J. \& SEGAL, Jeffrey A. The Supreme Court and the attitudinal model. Cambridge: Cambridge University Press, 1993.

SZATMARY, David P. Shay`s Rebellion: the Making of an Agrarian Insurrection. United States of America: The University of Massachusetts Press, 1980.

SUNSTEIN, Cass. The Partial Constitution. Cambridge: Harvard University Press, 1998. 
One Case at a Time: Judicial Minimalism on the Supreme Court. Cambridge: Harvard University Press, 2001.

. Testing minimalism: a reply. Michigan Law Review, v. 104, 2005.

TORRES, Ricardo Lobo. Tratado de direito constitucional financeiro e tributário. Rio de Janeiro: Renovar, 2005, vol. II e vol. IV.

TURNER, Kathryn. The Midnight Judges. University of Pennsylvania Law Review, v. 109, n. 4, 1961.

TUSHNET, Mark. Policy Distortion and Democratic Debilitation: Comparative Illumination of the Counter-Majoritarian Difficulty, Michigan Law Review, v. 94, 1995.

Weak Courts, strong rights - Judicial Review and social welfare rights in comparative constitutional law. New Jersey: Princeton University Press, 2008.

UNGER, Roberto Manguabeira. Knowledge and Politics. United States of America: Free Press, 1975.

URBINATI, Nadia. O que torna a representação democrática, paper apresentado no Encontro Anual da American Political Science Association (Apsa), tradução de Mauro Soares. Washington (EUA), setembro de 2005.

Representative Democracy: Principles and Genealogy. Chicago: University of Chicago Press, 2008.

VERÍSSIMO, Marcos Paulo. A Judicialização dos Conflitos de Justiça Distributiva no Brasil: o Processo Judicial no Pós-1988. Tese de Doutorado em Direito Processual Faculdade de Direito, Universidade de São Paulo, São Paulo, 2006.

WALDRON, Jeremy. Law and Disagreement. Oxford: Oxford University Press, 1999.

115, 2006. . The core of the case against judicial review. Yale Law Journal, v.

WALUCHOW, Wil. A Common Law theory of Judicial Review: The Living Tree. Cambridge: Cambridge University Press, 2007.

WHITTINGTON, Keith E. Constitutional Interpretation: Textual Meaning, Original Intent, and Judicial Review. University Press of Kansas, 1999.

28, n. 5, 2000. . Review Essay: In Defense of Legislatures. Political Theory, v.

An “indispensable Feature”? Constitutionalism and judicial review. NYU Journal of Legislation and Public Policy, 2002-2003.

Legislative sanctions and the strategic environment of judicial review. I-Con: The International Journal of Constitutional Law, v. 1, July 2003. 
ZAGREBELSKY, Gustavo. A crucificação e a democracia, Tradução Mônica de Sanctis Viana. São Paulo: Saraiva, 2011. 